\title{
BUENAS RAZONES, MALAS INTENCIONES (Sobre la atribución de intenciones)
}

Daniel González Lagier Universidad de Alicante

\section{El problema en el Derecho. La prueba de la intención.}

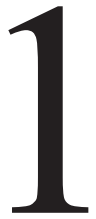

. Alfredo y Herminio vivían en huertas colindantes. Una tarde de Mayo, Alfredo llamó a grandes voces a Herminio, con el que anteriormente había mantenido múltiples y acaloradas discusiones. Al asomarse éste a la puerta de su casa entablaron una fuerte discusión sobre la propiedad de una vereda que separaba ambas fincas. La discusión fue interrumpida por el yerno de Herminio, quien asiéndole del brazo lo metió en la casa. A continuación Alfredo entró en su propia casa, cogió una escopeta IS, modelo PR, del calibre 12 y volvió a salir, retando a Herminio a gritos; le seguía su hermana Arsenia, quien, agarrándole del brazo, trataba de disuadirle. Cuando Herminio se asomó de nuevo a la puerta, Alfredo le disparó un cartucho de perdigones desde una distancia de unos 12 metros. En el momento en que Alfredo disparaba, Arsenia tiró de él hacia atrás para desviar la trayectoria del disparo. Los perdigones impactaron en un muro de piedra que estaba detrás de Herminio (a un metro de altura), sin que éste resultara lesionado. Se calculó que la trayectoria del disparo se había desviado $70 \mathrm{~cm}$. respecto de la que hubiera matado o herido a Herminio. Estos hechos fueron calificados por el tribunal que los juzgó como un delito de homicidio en grado de tentativa, lo que significa que se dio por probado (a) que la acción de Alfredo fue intencional y (b) que su intención era la de matar a Herminio y no meramente lesionarle (en cuyo caso se le podría haber condenado de un delito de lesiones en grado de tentativa $)^{1}$.

Los jueces de asuntos penales deben enfrentarse con frecuencia a casos en los que, como en éste, han de tratar de determinar si el acusado realizó una acción intencionalmente y qué intención era la que tenía. También en el

\footnotetext{
${ }^{1}$ STS 1843/1999, de 23 de Diciembre.
} 
ámbito civil es importante la prueba de la intención y otros hechos psicológicos, como el consentimiento, el conocimiento de ciertas circunstancias, la buena o mala fe, etc. ${ }^{2}$

Probar una intención es una tarea complicada. Las intenciones no son hechos observables. Si la prueba de los hechos externos ya entraña en ocasiones un alto nivel de dificultad, la prueba de los hechos internos o psicológicos parece añadir la complicación de que se trata de hechos que no pueden ser conocidos directamente por observación y respecto de los cuales sólo el agente que los tiene puede acceder a ellos -y seguramente no siempre, ni a salvo de errores- a través de la introspección, esto es, a través de un tipo de conocimiento peculiar que no requiere evidencia empírica (al menos externa) $)^{3}$.

2. La doctrina procesal y la jurisprudencia se han ocupado en ocasiones de la prueba de los hechos internos o subjetivos. Al no ser observables, los hechos psicológicos -se dice- no son susceptibles de prueba directa (salvo en las situaciones en las que se decide dar valor probatorio a la confesión autoinculpatoria $\left.{ }^{4}\right)$, sino de prueba indirecta o de indicios ${ }^{5}$. Esto es, nadie puede haber visto que un sujeto tenía una determinada intención (o una creencia, o una emoción), por lo que los estados mentales deben ser inferidos (o presumidos) a partir de la conducta externa del agente al que se atribuyen y de las circunstancias contextuales:

"La prueba de los elementos subjetivos del delito no requiere necesariamente basarse en las declaraciones testificales o en pruebas periciales. En realidad, en la medida en que el dolo o los restantes elementos del tipo penal no pueden ser percibidos directamente por los sentidos, ni requiere para su comprobación conocimientos científicos o técnicos especiales, se trata de elementos que se sustraen a las pruebas testificales y periciales en sentido estricto. Por lo tanto, el Tribunal de los hechos debe establecerlos a partir de la forma exterior del comportamiento y sus circunstancias mediante un procedimiento inductivo, que, por lo tanto, se basa en los principios de la experiencia general" ${ }^{6}$

${ }^{2}$ Taruffo [2002], pág. 159. Para un resumen de los problemas suscitados por la prueba de los hechos internos véanse las págs. 159 a 165 .

${ }^{3}$ S. Hampshire y H.L.A. Hart [1958], pág. 3.

${ }^{4}$ Taruffo [2002], pág. 162.

${ }^{5}$ Ramón Ragúes [1999], págs. 237 y ss. Patricia Laurenzo Copello [1999], págs. 124 y ss. Como tal prueba indiciaria, debe someterse a determinados requisitos. Entre otros: (a) Los indicios a partir de los cuales se realiza la inferencia -en nuestro caso, la conducta externa y sus circunstancias- deben obtenerse a partir de «prueba directa», esto es, no deben ser a su vez la conclusión de otra inferencia indiciaria (STS de 14 de Octubre de 1986; en contra de este requisito Belloch Julbe [1992], pág. 67.); (b) los indicios deben conducir de modo unívoco a inferir el elemento interno, esto es, no debe existir una inferencia alternativa igualmente probable (Belloch Julbe [1992], págs. 70 y ss.).

${ }^{6}$ STS de 20 de Julio de 1990. 
Así, en el ejemplo anterior, de acuerdo con el tribunal, para determinar qué intención tuvo Alfredo al disparar hay que prestar atención a las siguientes circunstancias: “a) Relaciones existentes entre el autor y la víctima. b) Personalidades respectivas del agresor y del agredido. c) Actitudes o incidencias observadas y acaecidas en los momentos precedentes al hecho, con especial significación de la existencia de amenazas. d) Manifestaciones de los intervinientes durante la contienda y del autor tras la perpetración del hecho criminal. e) Condiciones de espacio, tiempo y lugar. f) Características del arma e idoneidad para lesionar o matar. g) Lugar o zona del cuerpo a la que se dirige la acción ofensiva con apreciación de su vulnerabilidad y de su carácter más o menos vital. h) Insistencia o reiteración en los actos agresivos. i) Conducta posterior del autor"7. Se espera que el examen de estas circunstancias permita determinar si Alfredo disparó para matar o sólo quería lesionar. El tribunal que juzgó este caso concluyó que sí hubo intención de matar.

Además, la jurisprudencia ha ido creando un catálogo de "indicios-tipo" aptos para inferir el dolo en distintos tipos penales (por ejemplo, para la receptación se considera indicio de la intención que el precio de adquisición sea notablemente inferior al valor real de la cosa, y para la distinción entre "animus necandi" y "animus laedendi" la idoneidad del arma usada o la importancia vital del lugar del cuerpo al que se dirigió el ataque $)^{8}$.

Como puede imaginarse, este método indirecto de prueba de la intención, de determinación indirecta de la verdad de los enunciados acerca de los estados mentales, aunque parece inevitable, suscita enormes dudas y dificultades. ¿Podemos alcanzar de esta manera suficiente certidumbre acerca de las intenciones de los acusados o demandados para tomar estas decisiones? Las dudas son tantas que el Tribunal Supremo ha llegado a negar que los hechos psicológicos sean realmente hechos y los ha considerado "juicios de valor" de naturaleza subjetiva ${ }^{9}$ (lo que ha propiciado que sean tratados como parte de la quaestio iuris en lugar de materia de prueba); y parte de la doctrina penal -en una dirección semejante- ha señalado que la prueba del dolo no es en realidad una actividad cognoscitiva, sino una atribución o imputación a partir de los "indicios-tipo".

3. Algunas dudas acerca de la validez de la prueba de los hechos internos tienen que ver con dudas más generales acerca de la fiabilidad de cualquier

\footnotetext{
${ }^{7}$ STS 1843/1999, de 23 de Diciembre.

${ }^{8}$ Sobre el problema de los indicios-tipo en la prueba del dolo, véase Laurenzo Copello [1999], págs. 132 y ss.

${ }^{9}$ Por ejemplo, STS de 2 de Febrero de 1988. Para una exposición y crítica de esta jurisprudencia véase Perfecto Andrés Ibáñez [1992], pág. 266 y ss.
} 
prueba indirecta o de indicios. Como éste no es un argumento específico contra la prueba de los hechos psicológicos, creo que es conveniente despejar este tipo de dudas antes de continuar avanzando.

La diferenciación entre prueba directa y prueba de indicios (o indirecta, circunstancial, presuntiva, etc.) es una distinción clásica (según Taruffo se encuentra con distintas formulaciones en todas las culturas jurídicas ${ }^{10}$ ), pero oscura $^{11}$. Miranda Estrampes resume como sigue la doctrina del Tribunal Constitucional español sobre esta distinción (lo que puede considerarse, al menos en nuestro país, la versión canónica de la distinción):

"La prueba directa es aquella en que la demostración del hecho enjuiciado surge de modo directo e inmediato del medio de prueba utilizado; la prueba indirecta o indiciaria es aquella que se dirige a mostrar la certeza de unos hechos (indicios) que no son los constitutivos del delito, pero de los que pueden inferirse éstos y la participación del acusado por medio de un razonamiento basado en el nexo causal y lógico entre los hechos probados y los que se trata de probar"12.

Y, en palabras de Taruffo: "Es prueba directa la que versa directamente sobre el hecho a probar. En cambio, se estará ante una prueba indirecta cuando esta situación no se produzca, es decir, cuando el objeto de la prueba esté constituido por un hecho distinto de aquél que debe ser probado por ser jurídicamente relevante a los efectos de la decisión" ${ }^{13}$. Así, por ejemplo, un interrogatorio o un documento sería una prueba directa si versa sobre el hecho principal (esto es, el hecho que, una vez calificado, pasará a formar parte del silogismo judicial) y prueba indirecta o de indicios si versa sobre otro hecho ${ }^{14}$.

La prueba indirecta se considera "un mal menor", necesario para evitar la impunidad de numerosos crímenes ${ }^{15}$, pero que ha de estar sometida a especiales controles ${ }^{16}$. Esto es así porque se sostiene que "[la] prueba directa es aquella que de forma inmediata ofrece un contenido probatorio concreto en

\footnotetext{
${ }^{10}$ Taruffo [2002], pág. 453.

${ }^{11}$ Sobre los distintos criterios con los que se ha trazado esta clasificación, véase Marina Gascón, [1999], págs. 87 y ss.

${ }^{12}$ De esta manera resume M. Miranda Estrampes [1997], pág. 218, la definición del Tribunal Constitucional. Esta sería la distinción canónica entre prueba directa y prueba indiciaria, pero se encuentran en la doctrina otras formas de trazar la distinción. Véase Marina Gascón [1999], pág. 88.

${ }^{13}$ Taruffo [2002], págs. 455 y 456.

${ }^{14} \mathrm{El}$ problema es qué significa «versar sobre». ¿Puede un hecho versar sobre otro hecho o necesariamente ha de tratarse de una relación entre un enunciado significativo y su referencia? $\mathrm{Si}$ la respuesta es que lo segundo -como parece concluirse de los ejemplos de pruebas directas e indirectas que suelen usarse- entonces tiene razón Bentham al decir que todas las pruebas reales (las constituidas por objetos) son indirectas. Bentham [2001], pág. 22.

${ }^{15}$ Véase, por ejemplo, la STC 174/1985, de 17 de Diciembre.

${ }^{16}$ STC 133/1995, de 25 de Septiembre.
} 
tanto surge de él, espontáneamente, la posibilidad de su valoración. Es, en fin, la prueba que aclara la investigación, permitiendo la convicción judicial sin necesidad de deducciones ni inferencias", mientras que la prueba indirecta requiere "llegar lógica y racionalmente, no de manera arbitraria y por las vías de la experiencia (...) al hecho consecuencia (...) que se quiere acreditar"17. De manera que, según la concepción canónica (jurisprudencial y también doctrinal) la mayor fiabilidad de la prueba directa consiste en que pasar de ella al hecho principal no requiere razonamientos, deducciones o inferencias.

Sin embargo, esta concepción me parece equivocada: Dejando de lado la dudosa afirmación de que siempre es más fiable una creencia espontánea (no razonada) que una creencia que es la conclusión de un razonamiento, parece evidente que la superioridad de la prueba directa sobre la indirecta no puede tener carácter general. Por ejemplo, una prueba directa basada en testigos que presenciaron el hecho enjuiciado (por lo que, de creerles, éste "surge de modo directo e inmediato"), pero que son en realidad poco creíbles, puede tener una solidez menor que una prueba de indicios basada en una muestra de ADN (que, sin embargo, se conecta con el hecho enjuiciado a través de un razonamiento con más pasos). Esto es así porque, en mi opinión, también en la prueba directa -y no sólo en la indirecta, como sostiene esta concepción- se requiere realizar una inferencia (hay que pasar, por ejemplo, del hecho "Ticio dice que vio a Cayo matar a Sempronio" al hecho "Cayo mató a Sempronio", lo que exige valorar la credibilidad del testigo, descartar la posibilidad de errores, etc. $)^{18}$. Esa inferencia debe valorarse de acuerdo con ciertos criterios de racionalidad epistemológica (que los filósofos han estudiado desde hace tiempo, y que coinciden con los que jurisprudencialmente se han venido estableciendo para la prueba de indicios): la cantidad de hechos probatorios, su diversidad, su pertinencia, su fiabilidad, el carácter más o menos fundado de las máximas que actúan de

\footnotetext{
${ }^{17}$ STS 572/1996, de 16 de Septiembre.

${ }^{18}$ A mi juicio, tiene razón Belloch Julbé cuando afirma que "no existen diferencias cualitativas entre la estructura de la prueba indiciaria y la estructura de las convencionalmente denominadas 'pruebas directas'. Piénsese en el ejemplo de un testigo que afirma haber presenciado cómo el acusado realizaba el correspondiente hecho delictivo. Tal testimonio, según las normas al uso, deberá calificarse de 'prueba directa' en cuanto recae sobre el epicentro de la eventual pretensión acusatoria y no sobre hechos periféricos íntimamente conectados con la dinámica comisiva. Pues bien, incluso en tal caso, podría hablarse de un hecho-base (un testigo que afirma haber presenciado los hechos), un proceso deductivo [léase, inferencial; como veremos más adelante, no necesariamente será una deducción. DGL] (no tiene el testigo razones o motivos para mentir, y además estaba plenamente capacitado para 'percibir' esa realidad que ahora transmite) y una conclusión lógica (debe ser verdad lo que el testigo narra que presenció)". Belloch Julbé [1992], págs. 42 y 43. También objetan con argumentos semejantes la distinción entre prueba directa e indirecta Luigi Ferrajoli [1997], págs. 130 y 131. Marina Gascón [1999], pág. 89.
} 
enlace entre el hecho probatorio y el hecho a enjuiciar, la coherencia de la conclusión... y si se trata de una inferencia con un único "eslabón" o se trata más bien de un encadenamiento de inferencias ${ }^{19}$. Es verdad que, cuantas más inferencias (cuanto menos directamente se conecte el hecho probatorio y el hecho a enjuiciar), y permaneciendo igual el resto de criterios, menos sólida es la argumentación en su conjunto, y esto es lo que tiene la prueba directa a su favor. Pero éste es sólo un criterio que hay que contrapesar con los demás. Por tanto, me parece equivocada la tesis de que la prueba de indicios es siempre menos sólida que la prueba directa, por lo que no puede fundamentarse aquí un rechazo de la posibilidad de probar las intenciones de los agentes.

\section{El problema en la filosofía. La explicación de la acción}

1. ¿Cómo deben explicarse las acciones humanas? ¿Cómo podemos explicar el hecho de que César cruzara el Rubicón, que un soberano declare una guerra, la aprobación de una ley en un parlamento o que mi amigo Pedro volviera la cabeza hacia otro lado cuando pasé cerca de él? Esta es una cuestión fundamental para las ciencias humanas, como la historia o la sociología. Y al hilo de esta cuestión se plantea de nuevo el problema del conocimiento de los estados mentales subjetivos de otros individuos. Profundizar en la teoría de la explicación de las acciones intencionales puede aportarnos instrumentos útiles para la prueba de la intención (y viceversa).

Explicar un acontecimiento o un hecho cualquiera $p$ es un acto de habla cuyo propósito es responder a la pregunta “¿por qué tuvo lugar $p$ ?”20. Una explicación de este tipo tiene, por tanto, la siguiente forma: " $p$ ha ocurrido porque $q " . q$ no puede ser cualquier cosa, sino que ha de guardar con $p$ cierta relación especial: una relación explicativa. Por supuesto, habría que indicar en qué consiste esta relación, pero eso depende de la teoría de la explicación que se asuma (y del tipo de explicación del que se hable). En todo caso, intuitivamente sabemos que hay ciertas cosas que resultan adecuadas para responder a la cuestión "por qué ha ocurrido $p$ " (todas ellas, como dice Searle, han de dar cuenta de la idea de "hacer que algo suceda" 21 ) y otras que no resultan respuestas ni siquiera prima facie satisfactorias. Aristóteles señaló cuatro factores o causas que tendrían poder explicativo. Supongamos que estoy jugando al billar y consigo meter una bola en la tronera al gol-

\footnotetext{
${ }^{19}$ Para un análisis de estos criterios véase Daniel González Lagier [2003].

${ }^{20}$ No obstante, identificar las explicaciones con la indicación de causas (o factores que provocan) el fenómeno que se quiere explicar es sólo una -aunque importante- de las concepciones posibles sobre la explicación. Para una introducción a otras concepciones de la explicación véase, por ejemplo, Gerald Baker y Len Clark [1994].

${ }^{21}$ John Searle [2000-b], pág. 125.
} 
pearla con el taco. ¿Por qué la bola ha entrado en la tronera? En palabras de Gerald Beker y Glen Clark - de quienes tomo el ejemplo-:

"1. La causa formal es la esencia o estructura, la configuración o forma del acontecimiento o del objeto. Al recurrir a los ángulos de impacto estaríamos sin duda refiriéndonos a la causa formal.

2. La causa material es la materia que interviene y que, en virtud de sus cualidades (de dureza y elasticidad, en el ejemplo anterior) puede hacer que un acontecimiento se produzca de una manera determinada.

3. La causa eficiente es aquello que inicia el movimiento en cuestión ("la causa primaria del cambio de estado, del paso al movimiento o al reposo"). En este caso hay toda una cadena de causas eficientes, empezando por la bola blanca y remontándose hasta el taco, el brazo, etc.

4. La causa final (o causa teleológica) es "aquella en razón de la cual se hace algo" que, en este caso, dando por supuesto que querías hacer el disparo que has hecho, sería el triunfo en el juego"22

Dos de estos factores explicativos han tenido una gran relevancia en la historia de la filosofía: la causa eficiente o mecánica y la causa final o teleológica. “¿Por qué Pedro está amarillo?”. "Porque tiene una concentración de bilis en la sangre". Este es un ejemplo de lo que hoy llamamos explicación causal (lo que Aristóteles llamaría una explicación indicando la causa eficiente). Las explicaciones causales están muy extendidas en las ciencias de la naturaleza y puede decirse que una característica de la ciencia moderna es tratar de dar respuestas en términos de explicaciones causales mecanicistas. En otras ocasiones podemos responder a la pregunta "¿por qué sucedió $p$ ?" señalando las consecuencias útiles de que $p$ haya ocurrido o la finalidad para la que sirve. “¿Por qué bombea el corazón?”. "Para impulsar la sangre por el cuerpo", podemos responder. Este sería un ejemplo de explicación funcional o final o teleológica (la validez de este tipo de explicación para las ciencias de la naturaleza ha sido muy cuestionada, porque si explicar algo es indicar qué es lo que ha hecho que suceda, parece presumir algún plan preconcebido o cierta capacidad de dirigirse a fines de los hechos naturales; por otro lado, también puede cuestionarse si las explicaciones funcionales y las teleológicas son del mismo tipo).

2. ¿Cuál de estos dos tipos de explicación es más adecuado cuando el explanandum es una acción? Sobre esto hay una extensa literatura filosófica. Una de las razones es que la respuesta que demos tiene implicaciones para la cuestión del método propio de las ciencias humanas: si pensamos que las acciones son susceptibles de explicación causal, entonces el modelo de explicación científica será el mismo para las ciencias humanas y las ciencias

${ }^{22}$ Gerald Baker y Len Clark [1994], pág. 52 
de la naturaleza (monismo metodológico). Si el tipo de explicación más apropiado para la acción es el teleológico (señalando los objetivos perseguidos por quien actúa, esto es, señalando con qué intención actúa o cuáles son las razones de su acción), entonces se abre la puerta a importantes diferencias metodológicas entre unas y otras ciencias (dualismo metodológico). Otra razón es que nuestra pregunta también puede tener implicaciones para el problema de la libertad humana y el determinismo: si nuestra conducta se puede explicar por causas mecánicas, entonces las acciones humanas parecen encontrarse inmersas en los mismos flujos de causalidad que cualquier fenómeno natural y resulta difícil dar cuenta de qué quiere decir que hemos elegido actuar como lo hemos hecho.

Una forma bastante extendida de plantearse el problema es el siguiente: A la pregunta “¿por qué Pedro volvió la cabeza hacia otro lado?” podemos responder de dos maneras: indicando las causas, en sentido mecánico, de ese hecho (por ejemplo, diciendo: "tiene una lesión muscular que le produce cierto tipo de espasmos") o dando las razones por las que lo hizo (por ejemplo, diciendo: "porque se ha enterado de que te han ascendido y creía que él lo merecía más"). Ahora bien, muchos autores aducen que estas explicaciones explican cosas distintas: la primera explica meramente ciertos movimientos corporales, pero no una acción; la segunda explica realmente una acción ${ }^{23}$ (y esto sería así incluso aunque las explicaciones se refieran al mismo tramo de conducta: un mismo comportamiento probablemente tiene siempre una explicación en términos de actividad neurofisiológica y otra en términos de razones, pero ambas explicaciones apuntan a dimensiones distintas del comportamiento). Esto es consecuencia de asumir un concepto de acción intrínsecamente relacionado con la idea de actuar por una razón o actuar intencionalmente. A las ciencias humanas les interesa la acción en cuanto que portadora de un significado, y no meramente como una serie de sucesos físicos y mecánicos. Otra posibilidad es responder que sí es posible dar una explicación en términos de relaciones causales de la acción realizada por razones, porque las razones son precisamente causa (en el sentido genuino) de las acciones. Es decir, podemos explicar una acción indicando las razones por las que el agente la realizó, pero eso no hace que la explicación deje de ser causal, porque las razones son causa de la acción ${ }^{24}$. Esta explicación sería, por tanto, al mismo tiempo causal e intencional ${ }^{25}$.

\footnotetext{
${ }^{23}$ Esta es una afirmación constante en la obra de von Wright. Véase, por ejemplo, von Wright [2002], pág. 117.

${ }^{24}$ Esta es la tesis defendida por Donald Davidson [1995].

${ }^{25}$ Frente a esta Tesis, la Tesis de la Conexión Lógica (no causal) entre intención y acción es defendida por von Wright [1987]. Para una comparación de las dos Tesis puede verse Frederick Stoutland [1980].
} 
No me interesa entrar en la cuestión de si la explicación por razones es una explicación causal o teleológica o de un tipo peculiar. Lo que me interesa destacar es la convergencia de opiniones respecto a que las acciones (a diferencia de los meros movimientos corporales) se deben explicar señalando la intención con la que se actuó o las razones que las impulsaron ${ }^{26}$.

3. Filósofos como Hempel y Popper han propuesto un modelo de explicación intencional de la conducta que toma como premisa general o ley de cobertura un Principio de Racionalidad ${ }^{27}$. Por ejemplo, el modelo nomológico-deductivo de Hempel (según el cual cualquier acontecimiento queda explicado cuando es la conclusión de un argumento deductivo que tiene como premisa general una ley y como premisa menor el explanans), puede adaptarse al caso de las acciones intencionales de la siguiente forma ${ }^{28}$ :

(1) $X$ deseaba $G$

(2) $X$ creía que hacer $A$, en ciertas circunstancias, es una (o la única, o la mejor) manera de lograr $G$

(3) Cuando un agente desea algo y cree que la realización de un cierto acto, en algunas circunstancias, es una (o la única, o la mejor) manera de satisfacer su deseo, realiza ese acto.

(4) Luego $X$ realizó $A$.

En este esquema, (3) enuncia el Principio de Racionalidad. Algunos autores consideran que el principio de Racionalidad tiene carácter empírico y, por tanto, falsable (Hempel); otros lo tratan como un presupuesto necesario para entender la conducta, pero que no informa acerca de cómo actúan de hecho las personas (Popper) ${ }^{29}$. A veces se considera un principio universal; otras veces, probabilístico. Pero tanto para unos como para otros la función del principio es la de permitir el paso de las intenciones y creencias a la acción efectivamente realizada (se trata de excluir la posibilidad de que el agente no actúe a pesar de tener las actitudes psicológicas adecuadas y de

\footnotetext{
${ }^{26}$ Esta misma idea se puede encontrar dentro de lo que Salvador Giner ha llamado la corriente sociológica principal, que asume los siguientes principios en cuanto a la explicación de la acción: "toda acción a) posee, para su autor, un significado subjetivo e intencional; b) no puede ser explicada racionalmente por quienes observan y analizan su desarrollo si tal significado no es tenido en cuenta; c) la explicación es posible, además, porque los seres humanos suelen actuar racionalmente, es decir, de acuerdo con su interpretación de la situación en que se encuentran (...)". Salvador Giner [1997]. pág. 40. Existe un cuarto presupuesto (que, como se verá después, también tiene interés para nuestro tema): "Una acción es, además, social, si d) su intencionalidad tiene en cuenta la existencia de otro u otros seres humanos".

${ }^{27}$ Para un estudio de los distintos modelos de explicación intencional de la conducta, con o sin Principio de Racionalidad, y para la propuesta de un modelo basado en un Principio de Racionalidad Mínima, véase Amparo Gómez Rodríguez [1992].

${ }^{28}$ La adaptación es de Peter Achinstein [1989], pág. 195.

${ }^{29}$ Así lo interpreta Muguerza [1992], pág. 8.
} 
que no haya ningún impedimento). También es frecuente por los autores que proponen este modelo señalar la importancia de lo que Popper llamó la lógica de la situación. Con esta expresión se quiere destacar que la explicación debe hacerse teniendo en cuenta el marco físico y el entorno social e institucional en el que actúa el agente, y su evaluación de todas estas variables ${ }^{30}$.

Los modelos propuestos por Hempel y Popper toman postura a favor del monismo metodológico en la discusión acerca de cuál es el método propio de las ciencias de la conducta. El Principio de Racionalidad opera como las leyes causales naturales; el tipo de explicación es en sustancia el mismo para las ciencias de la naturaleza y las ciencias del hombre. Von Wright ha propuesto, por el contrario, un modelo distinto (sin Ley de Cobertura, aparentemente) en su defensa del dualismo metodológico. Su propuesta es que el silogismo práctico aristotélico puede ofrecer el patrón de explicación propio de la acción humana. El siguiente sería el esquema del silogismo práctico:

(1) $A$ tiene intención de $p$

(2) $A$ juzga que a menos que haga $q$ no será capaz de dar lugar a $p$.

(3) Por consiguiente, $A$ se dispone a hacer $q$.

"Es fácil percatarse - dice von Wright- de lo que tiene que ver el razonamiento práctico con la explicación de la acción. Supongamos que $A$, de hecho, hace $q$. Deseamos saber por qué. Una respuesta satisfactoria a esta cuestión sería señalar que tenía la intención de $p$ y que consideraba hacer $q$ necesario para este fin. Y esta misma respuesta explicaría por qué trató de hacer $q$ en una situación en la que terminará fracasando"31 . En realidad, la propuesta de von Wright parece diferir de la de Hempel y Popper sólo en la ausencia del Principio de Racionalidad. En su lugar, el modelo de von Wright asume que podemos inferir una acción a partir de creencias y deseos (intenciones) por razones conceptuales: "Decir que tales y cuales intenciones y creencias, en el caso de que no cambien, darán normalmente como resultado tal y cual conducta no es establecer una generalización empírica basada en observaciones y experimentos. Es establecer una verdad necesaria que aceptará sin dar más vueltas todo aquél que se halle familiarizado con los conceptos involucrados" ${ }^{32}$. De manera que la regla de inferencia que nos permite inferir la acción a partir de las creencias y los deseos tiene carácter conceptual.

Sin embargo, ni uno ni otro modelo de explicación ${ }^{33}$ dan cuenta de todas las fases de la explicación intencional de una acción. No se refieren a cómo

\footnotetext{
${ }^{30}$ Amparo Gómez Rodríguez [1992], pág. 27. Salvador Giner [1997], pág. 27 y ss.

${ }^{31}$ Von Wright [1980-a], pág. 185.

${ }^{32}$ Von Wright [1980-b], Freedom and Determination, pág. 57.

${ }^{33}$ Que, en realidad, no son sino refinamientos de lo que podríamos llamar el "modelo de la psicología de sentido común", esto es, el que aplicamos cotidianamente al explicar y predecir
} 
obtenemos el deseo y las creencias que usamos para explicar la acción (salvo la indicación sobre la importancia de tener en cuenta la lógica de la situación), sino sólo de cómo queda explicada la acción una vez que tenemos esos datos ${ }^{34}$. En otras palabras: nos dicen que una acción queda correctamente explicada desde un punto de vista intencional cuando puede inferirse de una premisa sobre las actitudes volitivas y epistémicas del agente y una premisa general (de carácter empírico, conceptual,...) que viene a establecer que los agentes actúan de acuerdo con sus deseos y creencias. Ahora bien, para que la explicación sea correcta, la premisa que establece cuáles son los deseos y creencias del agente debe ser verdadera ${ }^{35}$. ¿Cómo podemos saber que lo es? Al preocuparnos por la justificación externa de la explicación, el problema de cómo conocer los estados mentales internos de los agentes aparece de nuevo, y se muestra que los modelos de explicación intencional de la conducta no lo afrontan.

\section{Probar, explicar y atribuir}

1. Parece claro que tanto la prueba de la intención como la explicación intencional de la acción requieren atribuir al agente una intención. Pero "atribuir" (o "adscribir"), en el uso común, es una expresión ambigua, que tiene un sentido fuerte y un sentido débil. Atribuimos culpas, responsabilidades, acciones, opiniones, creencias, deseos, intenciones, emociones... La palabra (en los usos que nos interesan ahora) siempre implica la asociación entre alguna de estas cosas y un individuo. La diferencia entre los dos sentidos tiene que ver con los criterios para realizar esta asociación. En un sentido débil de "atribuir", los criterios de atribución residen en última instancia en la correspondencia entre la atribución ("Cayo creía que hoy iba a llover") y la realidad. "Atribuir", en este sentido, es un tipo de descripción que puede ser verdadera o falsa. En sentido fuerte, "atribuir" es un uso del lenguaje distinto de describir: en este sentido, el criterio para determinar si una atribución es correcta o no ya no depende de la correspondencia con la realidad, sino de la aplicación correcta de reglas de atribución cuyo objetivo no es descubrir la verdad (no son criterios de racionalidad epistemológica) sino resolver conflictos de intereses o satisfacer determinados fines prácti-

la conducta de los demás recurriendo a sus creencias y deseos. Véase Josefa Toribio Mateas [1995], pág. 246.

${ }^{34}$ Von Wright, sin embargo, sí hace algunas consideraciones acerca de cómo verificamos las premisas del silogismo práctico (la intención y las creencias), para mostrar la conexión lógica entre éstas y la conclusión (la ocurrencia de la acción no puede verificarse si no es por referencia a la ocurrencia de las premisas y viceversa). Von Wright [1987], págs. 135 y ss.

${ }^{35}$ Así como la premisa que establece el Principio de Racionalidad debe ser aceptable empírica o conceptualmente o como un presupuesto epistemológico. 
cos. La corrección de la atribución ya no es entonces una cuestión de verdad o falsedad, sino de eficacia en la satisfacción de los intereses o fines.

En palabras de Joel Feinberg, de quien tomo la distinción:

"Debo decidir en qué restaurante cenar mañana, pero debo descubrir la solución de una ecuación o la población de una ciudad. En el primer caso, incluso después de pesar todas las circunstancias, conservo cierta libertad de elección; en el último caso los hechos me obligan o me comprometen totalmente: no puedo evadir las conclusiones que me dictan. Se ha expresado esta distinción de muy distintas maneras: cuestiones de objetivos frente a cuestiones de hecho, prácticas frente a teóricas, normativas frente a constitutivas, y así sucesivamente. Algunos filósofos han negado la distinción: los "Platónicos" tienden a reducir las cuestiones de decisión a cuestiones de descubrimiento y los "Pragmatistas" asimilan las teóricas a las prácticas. El sentido común, sin embargo, se aferra a la distinción aunque no sepa cómo explicarla o trazar la línea divisoria. Sugiero que los filósofos que contraponen 'atributivo' a 'factual' están pensando en esta distinción. Por enunciados atributivos entienden (entre otras cosas) enunciados que no son completamente teóricos o factuales, sino que tienen un aspecto de discrecionalidad irreductible" ${ }^{36}$.

En definitiva, señala Feinberg, las atribuciones en sentido fuerte se caracterizan por (a) implicar un grado irreductible de discrecionalidad (no consisten tanto en descubrir como en decidir), (b) ser relativas a nuestros intereses y (c) ser revocables ${ }^{37}$. Podemos llamar a las atribuciones en sentido débil "atribuciones teóricas" y a las atribuciones en sentido fuerte "atribuciones normativas" o "imputaciones".

Ahora bien, como ocurre con muchas otras distinciones, se trata de una distinción útil, pero que debe matizarse. Hay ciertas consideraciones que invitan a relativizarla, porque muestran una "contaminación" de lo teórico con lo práctico: En primer lugar, las atribuciones teóricas requieren muchas veces de meticulosos razonamientos, de cuyas conclusiones no estamos completamente seguros, por lo que asumirlas requiere, en cierto sentido, de algo semejante a una decisión. En segundo lugar, uno de los criterios para aceptar -aunque sea provisionalmente- la verdad de una teoría científica es su utilidad para explicar y predecir fenómenos ${ }^{38}$. Esto no implica abandonar una teoría de la verdad como correspondencia por una teoría pragmatista de la verdad, pero sí introducir criterios pragmáticos entre los síntomas de la verdad. Este sería un "contenido mínimo de pragmatismo en la idea de verdad", que haría que nuestros intereses tuvieran alguna participación en muchas de nuestras investigaciones teóricas. En tercer lugar, a veces una atribución teórica es necesaria para perseguir un fin práctico, como,

\footnotetext{
${ }^{36}$ Joel Feinberg [1968], pág. 111.

${ }^{37}$ Joel Feinberg [1968], págs. 110 y ss.

${ }^{38}$ Nicholas Rescher [1994], pág. 64.
} 
por ejemplo, cuando un médico necesita atribuir el color amarillo de un paciente a alguna causa, con el fin de curarle. En cuarto lugar - pero es una circunstancia que me interesa mucho recalcar, por las razones que se verán más adelante-, a veces se habla de reglas de atribución para hacer referencia a criterios que en realidad tienen una finalidad epistemológica y una fundamentación inductiva. Una atribución hecha a partir de estas reglas de racionalidad epistemológica es una atribución teórica, pero es posible que se acabe perdiendo de vista la fundamentación última de estas reglas y se las acabe considerando simplemente como reglas de atribución en sentido fuerte. Creo que esto es lo que ocurre en ocasiones con las llamadas teorías adscriptivistas de la acción (y de la intención) ${ }^{39}$.

A pesar de todo lo anterior la distinción es importante, y se mantiene en el siguiente sentido: (a) Quien hace una atribución necesariamente debe tener o bien una pretensión en última instancia descriptiva (aunque sus fines últimos sean prácticos) o bien una pretensión en última instancia normativa. No puede tener simultáneamente ambas pretensiones. (b) Lo que muestra si un sujeto tiene una u otra pretensión es su disposición o no a aceptar que la atribución sea revocable por consideraciones de verdad o falsedad. Por ello, los que sostienen que las intenciones se imputan, no se describen, no pueden coherentemente aceptar como criterio de revocación que la imputación no coincida con la realidad mental.

2. ¿Qué tipo de atribución requiere la explicación intencional de una acción? Si realmente se tiene la pretensión de que señalar la intención dé cuenta de por qué el agente realizó la acción, me parece que la atribución debe ser teórica o descriptiva. De otra manera, podemos comprender el sentido objetivo de la acción y quizá, incluso, justificarla, pero no explicarla intencionalmente (lo que no excluye que una misma intención explique y justifique la acción simultáneamente; sería el caso de lo que Searle llama explicaciones justificativas ${ }^{40}$ ). Sólo podemos explicar una acción si señalamos la razón por la que realmente el agente hizo lo que hizo (su intención real). No basta con señalar que había una razón para actuar, sino que hay que postular que el agente actuó movido por esa razón. Quienes niegan la posibilidad de describir con cierto grado de objetividad las intenciones ( $u$ otros estados mentales relevantes), deben rechazar la posibilidad de explicar las acciones a la luz de razones (más adelante trataré de mostrar que actuar

${ }^{39}$ La teoría adscriptivista de la acción fue defendida por H.L.A. Hart [1948]. Para un resumen de esta tesis puede verse Daniel González Lagier [2001], especialmente págs. 53 y ss. Una defensa reciente de la teoría adscriptivista de la acción puede encontrarse en Rafael Alcácer Guirao, Cómo cometer delitos con el silencio. Notas para un análisis del lenguaje de la responsabilidad.

${ }^{40}$ Searle [2000-b], pág. 130. 
intencionalmente es actuar por una razón). Deberán explicar la conducta en términos causales cuyo antecedente no sean intenciones, razones, deseos, etc., sino estados neuronales o compulsiones físicas. No explicarán, en definitiva, acciones, sino movimientos corporales.

¿Qué tipo de atribución requiere la prueba de la intención? Puede pensarse que la prueba judicial, en general, es una actividad orientada a establecer la verdad de ciertos enunciados, y que "verdad" aquí debe significar "verdad como correspondencia con la realidad". Taruffo, por ejemplo, señala que la determinación de que el hecho probado ha ocurrido realmente es condición necesaria de la justificación plena de la decisión judicial ${ }^{41}$. Ésta no es una tesis unánimemente aceptada, pero me parece esencialmente correcta (aunque defenderla aquí nos llevaría demasiado lejos). Si esto es así, la prueba de la intención ha de consistir, como en el caso de la explicación, en una atribución teórica.

Sin embargo, muchos de quienes aceptan que la prueba judicial de los hechos es una cuestión de correspondencia con la realidad lo niegan a propósito de la prueba del dolo o de la intención ( $\mathrm{y}$, en realidad, también hay quien lo niega a propósito de la explicación de la acción). Sostienen que atribuir una intención consiste en asignar a la acción un significado objetivo que depende de ciertas reglas cuya función última no es averiguar la realidad, sino satisfacer otros fines (asignar un significado a la acción a pesar de la imposibilidad de probar qué es lo que quiso el agente, resolver satisfactoriamente un caso, hacer inteligible la decisión judicial para la sociedad, etc.). Para estos autores, la prueba de la intención no sería, por tanto, prueba o demostración, sino imputación.

Los distintos argumentos para negar la intención (esto es, para negar el carácter descriptivo de las atribuciones de intención) pueden agruparse -al menos- en cuatro tipos (los dos primeros de carácter ontológico; el tercero de carácter epistemológico y el cuarto de tipo ideológico):

a) No existen entidades mentales (por lo tanto, no hay nada que descubrir).

b) Existen entidades mentales, pero no con las propiedades que le atribuye la psicología de sentido común o el Derecho penal (por lo tanto, lo que hay que descubrir es algo distinto de lo que dice el Derecho penal).

c) La intención (y con ella, probablemente, el resto de entidades mentales) no puede conocerse con certeza (por lo tanto, es inútil tratar de descubrirla).

d) La intención como estado mental no importa realmente en el proceso (por lo tanto, no es pertinente tratar de descubrirla).

\footnotetext{
${ }^{41}$ Michele Taruffo [2003], pág. 39.
} 


\section{La negación de la intención (I): El argumento ontológico}

1. Los estados mentales son entidades muy "incómodas" para los filósofos, porque pueden tener ciertas propiedades (consciencia, contenido, subjetividad y capacidad de interactuar con el mundo físico) que no cuadran bien con una concepción científica del mundo ${ }^{42}$.

La consciencia es un rasgo de muchos estados mentales que ya fue señalado por Descartes (para quien precisamente era el rasgo definitorio de lo mental). Podemos entenderla como una especie de conocimiento "de lo que sucede dentro de nosotros" ${ }^{43}$ no fundado en la evidencia empírica acerca de rasgos del mundo externo: Si me pellizco el brazo, experimento dolor y por ello sé que el brazo me duele, y lo sé con independencia de que me vea a mí mismo sacudirlo o gritar; si deseo un vaso de cerveza, sé que lo deseo, sin necesidad de esperar a ver si me levantaré e iré a la nevera; y si estoy preocupado, sé -porque lo siento- que lo estoy (esta sería una consciencia de primer nivel; cuando soy consciente de mí mismo como experimentando un dolor o deseando una cerveza o preocupado tengo una consciencia de segundo grado o autoconsciencia). Ahora bien, hay cierta diferencia cualitativa en cómo experimento mi dolor, mi deseo o mi preocupación. Decimos entonces que estos estados mentales se corresponden con diferentes sensaciones internas o qualia. Los qualia son la manera peculiar como cada estado mental emerge a mi consciencia.

Otra característica de muchos estados mentales consiste en poseer un contenido mental, esto es, en su capacidad de versar o ser sobre objetos y estados de cosas del mundo (que, además, no tienen por qué existir en realidad) distintos de ellos mismos ${ }^{44}$. La creencia de que mañana lloverá se refiere a un contenido ("mañana lloverá"). Dado un estado mental con contenido, podemos distinguir entre su contenido y su modo psicológico ${ }^{45}$ : "Creo que mañana lloverá" y "Deseo que llueva mañana" son dos estados mentales que se diferencian por su modo psicológico, pero no por su contenido.

La tercera característica incómoda de los estados mentales es su subjetividad. Mis dolores, temores, odios, deseos y creencias son exclusivamente míos, por lo que yo puedo ser consciente de mis estados mentales, pero no de los de otros, ni otros pueden serlo de los míos. En opinión de Searle se

\footnotetext{
${ }^{42}$ John Searle [1985], págs. 19 y ss.

${ }^{43}$ Manuel García Carpintero [1995], pág. 46.

${ }^{44}$ John Searle [1992], pág. 18. A esta característica se le llama normalmente intencionalidad, pero no debe confundirse la intencionalidad como característica general de los estados mentales con el estado mental concreto que llamamos intención. Para evitar la confusión, usaré la expresión -menos frecuente en la filosofía de la mente-contenido mental.

${ }^{45}$ John Searle [1992], pág. 21.
} 
trata más de una subjetividad ontológica que epistemológica: "Consideremos, por ejemplo, el enunciado 'tengo dolor de espalda'. Tal enunciado es completamente objetivo en el sentido de que lo convierte en verdadero la existencia de un hecho real y no depende de las actitudes de los observadores. Sin embargo, el fenómeno mismo, el dolor real mismo, tiene un modo subjetivo de existencia"46.

A todas estas propiedades hay que añadir otro factor de perplejidad a propósito de los estados mentales: el hecho de que interactúen con estados físicos. Los estados mentales parecen causar hechos externos, físicos: nuestras emociones, creencias y deseos causan nuestro comportamiento. Mi miedo a que un perro me muerda causa que salga corriendo y mi deseo de saciar la sed, junto con las creencias adecuadas, causa que vaya a la nevera a por una cerveza.

Las intenciones tienen todas estas propiedades. La consciencia de la intención consiste en el conocimiento o certeza, no basada en evidencia empírica externa, que tenemos cuando pretendemos hacer algo: si se trata de la intención de hacer algo en un futuro próximo o lejano, la certeza de que -a menos de que algo me lo impida o cambie de opinión- efectivamente lo haré; si se trata de la intención en el momento de actuar, el conocimiento del tipo de acción que estoy realizando ${ }^{47}$. El contenido mental de la intención consiste en las acciones u objetivos que procuro realizar o alcanzar. La subjetividad ontológica consiste en el carácter privado y particular de las intenciones (hay cierto sentido en que otro sujeto y yo no podemos compartir la misma intención, porque mi intención es sólo mía: aunque tengamos intenciones de hacer lo mismo). Por último, la intención tiene alguna relación con mi conducta física, ejerce algún control sobre ella (incluso si se quiere evitar hablar de relación causal, como preferiría, por ejemplo, von $\mathrm{Wright}^{48}$ ).

El problema es que todos estos rasgos chocan con varios postulados de nuestra imagen científica del mundo, como la creencia de que las únicas cosas que existen son físicas y el postulado de que todo lo real es (ha de ser) objetivo, observable, público y verificable. ¿Cómo puede un cerebro, algo completamente material, tener consciencia? ¿Cómo puede versar sobre algo? ¿Cómo puede ser real algo esencialmente subjetivo? ¿Y cómo puede lo mental interactuar con lo físico? El problema es tratar de hacer compatible el rechazo del dualismo cartesiano (que sostendría que la mente es un tipo

${ }^{46}$ John Searle [1996], pág. 106.

${ }^{47}$ Stuart Hampshire y H.L.A. Hart [1958], págs 1 y ss.

48 “Arguyo contra una 'teoría causal de la acción'. Pero no estoy negando que, por ejemplo, los deseos o las necesidades puedan tener una influencia causal en la conducta”. Von Wright [1987], pág. 121. 
de sustancia distinta de los cuerpos) con la explicación de estas propiedades de las entidades mentales.

2. Una manera radical de "solucionar" estas perplejidades consiste en negar la existencia de entidades mentales. Podemos llamar a esta vía "eliminacionismo"; es el camino seguido por el conductismo lógico (que sustituye los estados mentales por disposiciones de conducta externa), el materialismo eliminacionista (que lo sustituye por estados cerebrales físicos) o la tesis de la "postura intencional" de Dennet (que postula que los estados mentales son sólo el resultado de adoptar cierta perspectiva para explicar las acciones, pero no son fenómenos intrínsecamente mentales). A continuación trataré de resumir estas posturas, pero el lector no interesado puede pasar directamente al punto 4 de este apartado.

De acuerdo con el conductismo lógico, términos como “dolor", “creencia", "emoción", "intención", etc. deben entenderse como referencias a ciertas disposiciones de comportamiento, y no a estados mentales internos. Si razonamos acerca de cómo aprendemos a usar estos términos, nos debemos dar cuenta - dicen los conductistas- de que el proceso de aprendizaje no va de lo "interno" a lo "externo": no reconocemos un dolor en nosotros mismos y luego aplicamos el concepto a otros, sino que aprendemos a usar el concepto a partir de las manifestaciones externas del dolor que observamos en los demás y en nosotros mismos. Por tanto, podemos traducir todos los conceptos mentales en términos de disposiciones a adoptar cierto tipo de conducta, o de la conducta que hipotéticamente tendría el agente en ciertas condiciones. Creer que lloverá se traduce en la propensión a coger un paraguas, a cancelar una comida campestre, etc. y tener un deseo o un propósito se traduce en la disposición a realizar la conducta causalmente adecuada para satisfacer un objetivo. Si podemos traducir los conceptos mentales en enunciados sobre conducta observable sin pérdida de significado, entonces no necesitamos postular la existencia de entidades mentales reales, por lo que podemos eliminarlos de nuestra concepción del mundo, de acuerdo con la navaja de Occam $^{49}$.

El materialismo eliminativo también niega la legitimidad de hablar de estados mentales. Ante ciertos problemas del conductismo ${ }^{50}$, un paso suge-

${ }^{49}$ Son conductistas autores como Rudolf Carnap, Gilbert Ryle y -con más matices- el segundo Wittgenstein (Manuel García Carpintero [1995], pág. 49).

${ }^{50} \mathrm{Al}$ definir los estados mentales en términos de conducta externa y al margen de las experiencias internas - esto es, de la consciencia de los estados mentales-, el conductismo se ve abocado a ciertas paradojas. Por ejemplo, tomemos la definición de "dolor" en términos de conductas (o propensiones a actuar) como gritar, lamentarse, etc. Tendríamos que decir que un superespartano que nunca expresara su dolor, ni siquiera en situaciones extremas -por ejemplo, al extraerle una muela sin anestesia- no tendría realmente dolor, y que un actor tan magnífico 
rido por los avances científicos consistió en identificar los estados mentales no con la conducta externa del individuo, sino con sus estados cerebrales (postura que se conoce como monismo, fisicalismo, materialismo o tesis de la identidad). Las Tesis de la identidad sostienen que cada tipo de estado mental se corresponde con algún tipo de estado cerebral (Tesis de la Identidad de Tipos) o que cada caso de estado mental se corresponde con un caso de estado cerebral, sin que sea posible generalizar esta correspondencia en el nivel de los "tipos" (Tesis de la Identidad de Instancias). Ante esta equivalencia entre estados mentales y estados cerebrales, o bien es posible la reducción de los primeros a los segundos (esto es, es posible explicar las propiedades de lo mental en términos materiales) o bien hay que concluir que los estados mentales no existen. Algunos materialistas - no todos- defienden este último paso. En lugar de limitarse a afirmar que no hay estados mentales separados de los estados cerebrales, afirman que no hay estados mentales en ningún sentido. Según ellos, a medida que avance la neurociencia, podremos sustituir el lenguaje de los estados mentales (y la teoría que los postula: la psicología de sentido común) por el lenguaje de los estados cerebrales, de igual manera que el descubrimiento de los virus y las bacterias permitió rechazar las explicaciones de las enfermedades en términos de demonios, maldiciones y espíritus. Éste sería, simplemente, un ámbito más donde la extensión de la ciencia permitiría la expulsión de la superstición ${ }^{51}$.

Tampoco existen los fenómenos mentales, como algo intrínsecamente mental, para Daniel C. Dennet. En su opinión, creencias, deseos, etc. son más bien una especie de método para explicar y predecir el comportamiento de un sistema que usamos cuando adoptamos lo que llama una "perspectiva intencional". Dennet distingue tres perspectivas o enfoques posibles cuando tratamos de explicar o predecir el comportamiento de un sistema (esto es, de un ser humano, un ordenador, un termostato, etc. $)^{52}$ : El primer tipo de enfoque es el de la "perspectiva del diseño": supongamos un termostato que regula el encendido y apagado de un aparato de calefacción. Podríamos predecir su "comportamiento" si conocemos su diseño, esto es, las reglas que

\footnotetext{
que pudiera fingir expresiones externas de dolor que engañaran a todos tendría, sin embargo, dolor. Otra objeción importante es que analizar determinados estados mentales nos lleva necesariamente a otros estados mentales, lo que convierte a las definiciones de los conductistas en circulares. Así, por ejemplo, "mi creencia de que llueve se manifestará en que yo me llevo un paraguas sólo si tengo también el deseo de no mojarme. Y mi deseo de no mojarme se manifestará en esta conducta de coger el paraguas sólo si tengo la creencia de que el paraguas me mantendrá seco". El hecho de que los estados mentales se relacionen de esta manera se conoce como la tesis del holismo de lo mental.

${ }^{51}$ Son materialistas eliminativos autores como Paul Feyerabend, Richard Rorty, Steven Stich y Paul y Patricia Churchland. Alfonso García Suárez [1995], pág. 359.

${ }^{52}$ Daniel C. Dennet [1985], págs. 11 y ss.
} 
gobiernan su actividad. De la misma manera, podríamos predecir las jugadas de un ordenador programado para jugar al ajedrez conociendo el programa. Después tenemos el enfoque de la "perspectiva física". Desde esta perspectiva, aplicamos nuestro conocimiento de las leyes de la naturaleza y del funcionamiento mecánico del termostato para predecir su comportamiento (sabemos que si determinada sustancia se dilata por efecto del calor, disparará el interruptor). Igualmente, si pudiéramos conocer perfectamente el aspecto físico y mecánico del funcionamiento de un ordenador (las descargas eléctricas que tienen lugar en su interior, por ejemplo), podríamos predecir igualmente las jugadas (aunque resultaría sumamente difícil). Por último, está la "perspectiva intencional", que normalmente usamos para predecir y explicar el comportamiento de aquellos sistemas con una complejidad tan elevada que hace poco factible los otros enfoques. Desde esta perspectiva tratamos de predecir y explicar el comportamiento presumiendo la racionalidad del sistema. Es entonces cuando hablamos de creencias, deseos e intenciones. Podemos predecir las jugadas del ordenador tratando de averiguar cuál será la jugada más adecuada desde un punto de vista estratégico, con lo que estamos atribuyendo al ordenador creencias (qué jugada es mejor) y deseos (ganar). Pues bien, para este autor toda la intencionalidad -también la de los seres humanos- no es más que una forma de hablar que surge de adoptar la postura intencional, y que podríamos eliminar si pudiéramos dar una explicación de nuestras acciones en términos de "diseño" (o programación) o en términos físicos. Pero mientras no podamos, el enfoque intencional nos permite explicaciones y predicciones útiles, aunque no infalibles. La única diferencia entre el ordenador y los seres humanos es que el primero es un producto del diseño de un ser humano, y el segundo el producto del diseño de nuestro genes, o de la selección natural, o algo semejante.

3. Otra alternativa, que también conduce a la negación de la intención, al menos tal como usualmente se entiende, consiste en rechazar una o más propiedades de lo mental (consciencia, contenido, subjetividad y eficacia causal), normalmente como consecuencia de la reducción de los estados mentales a estados cerebrales físicos. Podemos llamar "reduccionismo" a esta alternativa. El reduccionismo no niega la legitimidad de hablar de estados mentales, pero al tratar de explicarlos en términos físicos los acaba convirtiendo en algo muy alejado de la noción de sentido común.

Como hemos visto, las teorías de la identidad sostienen que lo que llamamos estados mentales son idénticos a estados del cerebro y del sistema nervioso central ${ }^{53}$. Estas teorías no niegan que existan estados mentales

${ }^{53}$ La Teoría de la Identidad de Tipos establece la identificación entre tipos de estados mentales y tipos de estados cerebrales (por ejemplo, “Todos los casos de "experimentar dolor por 
(salvo, como hemos visto, el materialismo eliminativo): lo que niegan es que sean algo distinto que estados del cerebro. Usando categorías de Frege, los teóricos de la identidad que no desean prescindir de los estados mentales podrían decir que los términos que se refieren a estados mentales y los que se refieren a estados cerebrales tienen la misma referencia, aunque diferente sentido. Esta es una tesis atractiva, porque permite mantener las características peculiares de lo mental sin postular que lo mental es una sustancia distinta de lo físico, es decir, sin postular dos modos de existencia distintos. En realidad, no obstante, lo que esta tesis hace no es otra cosa que sustituir el dualismo de sustancias cartesiano por un dualismo de propiedades: aunque se elimina una sustancia (lo mental), se preservan las propiedades de lo mental como distintas de las propiedades físicas. Habrá que explicar por tanto cómo es que lo físico puede tener propiedades tan dispares. Una consecuencia frecuente del esfuerzo por explicar el funcionamiento de lo mental como resultado de ciertos rasgos físicos es acabar rechazando a una o más de las propiedades de lo mental. Esto es lo que ocurre, según Searle, con ciertas versiones del funcionalismo y de las teorías de la Inteligencia Artificial Fuerte.

El funcionalismo surge como un intento de superar una objeción a las Tesis de la Identidad de Instancias. Si dos individuos tienen el mismo estado mental, pero ello no implica que estén en el mismo estado cerebral (estarán ambos en algún estado cerebral, pero la teoría no postula que tengan que estar en el mismo), ¿qué es lo que hace que podamos decir que tienen un estado mental del mismo tipo? La respuesta obvia es que se trata del mismo tipo de creencia porque tienen el mismo contenido. Pero ésta es una respuesta mentalista que los teóricos de la identidad no pueden dar si quieren eliminar lo mental o reducirlo a lo físico. Todos los que creemos que Alicante está a orillas del Mediterráneo tenemos una creencia del mismo tipo; de acuerdo con la teoría de la identidad como instancia, eso no implica que tengamos el mismo tipo de estado cerebral o neuronal. ¿En qué consiste, entonces, si no es el contenido de la creencia y la manera de experimentarla, lo que nos permite decir que tenemos la misma creencia? Los funcionalistas responden que lo que nos permite clasificar los estados mentales son sus efectos causales (y los inputs que los provocan). Los estados mentales se definen y se distinguen unos de otros atendiendo a los inputs que los suscitan y los outputs que causan. La creencia de que va a llover, por ejemplo, es suscitada por ciertos estados del mundo y a su vez provoca (en combinación con el

\footnotetext{
una quemadura' se corresponden con un mismo tipo de excitación neuronal"), mientras que la Teoría de la Identidad de Instancias establece solamente que cada estado mental es idéntico a un estado cerebral, pero no siempre al mismo.
} 
deseo de no mojarme) una serie de acciones: coger un paraguas, por ejemplo. Y esto es lo que todas las creencias de que va a llover tienen en común. Obsérvese que el funcionalismo, a diferencia del conductismo, no identifica los estados mentales con la conducta (esto es, con sus posibles efectos), sino con algo (sea lo que sea) que media entre los inputs y los outputs. Pero el funcionalismo también puede ser eliminacionista: puede sostener -a la manera de Alf Ross en Th-Th con los conceptos normativos- que los estados mentales no existen en realidad -podemos eliminar ese algo que media- y son sólo una manera de expresar abreviadamente una serie de inputs y de outputs.

Un tipo de funcionalismo es el que Searle llama Inteligencia Artificial Fuerte. Esta concepción trata de explorar la siguiente analogía: la mente es al cerebro lo que el software es al hardware de un ordenador. La mente no sería otra cosa que un conjunto de símbolos y de reglas para manejar tales símbolos $^{54}$, esto es, un programa (las teorías de la Inteligencia Artificial Débil no hacen esta equiparación, pero toman la analogía como un instrumento de análisis de lo mental). Es el programa lo que conecta los estímulos con los efectos causales. De esta manera, las cuestiones semánticas (la intencionalidad, por ejemplo) se traducirían en cuestiones sintácticas.

Muchos defensores del funcionalismo y de la Inteligencia Artificial Fuerte, aunque no desean negar la existencia de estados mentales, rechazan la consciencia y el contenido mental, dada la dificultad de explicar desde sus principios las experiencias que tenemos de nuestros estados mentales o el hecho de que éstos posean un significado. Tampoco pretenden dar cuenta de la subjetividad de los estados mentales, ya que adoptan el punto de vista objetivo hacia los mismos, tratando de presentarlos como algo que podríamos describir desde el punto de vista de terceros, esto es, a partir de evidencia empírica que terceros podrían obtener.

Otras posturas niegan otros rasgos de lo mental, como su eficacia causal. Esta tesis se conoce como Epifenomenalismo. Dadas las dificultades para explicar cómo lo mental puede tener influencia causal en lo físico, es tentador sugerir que, en realidad, no lo tiene. Cada vez que tenemos estados mentales, tenemos ciertos estados cerebrales subyacentes (que causan lo mental), y son éstos $-\mathrm{y}$ no los estados mentales- los que tienen eficacia causal. Los estados mentales no causan nada (ni estados físicos, sean externos o del nivel inferior, ni otros estados mentales), y en realidad no son sino un subproducto o residuo de la actividad cerebral, como - por usar una metáfora extendida en estas discusiones- el sonido de la sirena de vapor

\footnotetext{
${ }^{54}$ Bechtel [1991], pág. 157.
} 
que acompaña al funcionamiento de una locomotora pero no influye en la maquinaria $^{55}$.

4. Puede parecer que los anteriores argumentos nos han llevado muy lejos de lo que estábamos discutiendo. Sin embargo, argumentos de este tipo (con menor sofisticación, en algunos casos) han sido usados por juristas para mostrar su pesimismo sobre la posibilidad de probar (en el sentido de atribución teórica) los estados mentales. Por ejemplo, Hruschka ${ }^{56}$ señala que

'No 'existen' hechos dolosos como tales, es decir, en el mismo sentido en que 'existen' hechos externos. 'Existen' en tan escasa medida como 'existe' la voluntad o la libertad humana, las acciones, la responsabilidad o la culpabilidad. Nos parecerá aun más sencillo si pensamos en que ningún científico natural, en tanto que tal, daría con estas cosas"

"Como todo lo espiritual, tampoco el dolo se determina y prueba, sino que se imputa. El juicio que emitimos al decir que alguien ha actuado dolosamente no es un juicio descriptivo, sino adscriptivo".

En España, también Paredes Castañón ha usado, con rigor, los argumentos de la filosofía de la mente para mostrar su pesimismo acerca de la posibilidad de probar el dolo con suficientes garantías ${ }^{57}$ (aunque sin defender la solución adscriptivista).

Sin embargo, la afirmación de que los estados mentales presentan las propiedades de consciencia, contenido, subjetividad e interacción con lo externo tiene un fuerte apoyo intuitivo. Por ello, todos los anteriores intentos de eliminar lo mental o alguna de sus propiedades (y las concepciones de la prueba de la intención que se basan en ellos) chocan con intuiciones básicas. Unos, como el conductismo y el materialismo eliminativo, nos dicen que no hay estados mentales; otros, como el funcionalismo o la Inteligencia Artificial Fuerte, que no hay lugar en ellos para la consciencia o el contenido mental; el epifenomenalismo, por último, niega la acción de lo mental sobre lo físico.

Lo que nos piden estas tesis es rechazar alguna de estas intuiciones ( 0 todas ellas!):

a) Normalmente puedo decir qué estados mentales tengo o qué procesos mentales me ocurren, y esto lo sé no por observación del mundo externo,

${ }^{55}$ Tomo la metáfora de Manuel Liz [1995], pág. 215. Paradójicamente, un autor como von Wright, que ha defendido que el tipo de explicación propio de las ciencias sociales es el intencional, al negar que los estados mentales tengan incidencia en los estados neuronales y negar simultáneamente que las intenciones sean causa de la acción, tiene dificultades para distanciarse del epifenomenalismo.

${ }^{56}$ Hruschka, Kleinknecht-Fs, pág. 200 y 201. Tomo la cita y la traducción de Ramón Ragués [1999], pág. 299.

${ }^{57}$ Paredes Castañón [2001], pág. 67. 
sino por ciertas "sensaciones internas" (los qualia correspondientes a tales estados).

b) Muchos de mis estados mentales no sólo tienen una sensación interna determinada, sino además un contenido: son representaciones de algo.

c) Mis estados mentales existen aunque sólo yo tenga acceso a ellos, esto es, aunque sean irreductiblemente subjetivos.

d) Lo que yo decida acerca de qué voy a hacer influirá en lo que efectivamente haga.

Si rechazamos estas intuiciones, no queda muy claro en qué sentido podríamos seguir hablando de estados mentales; sin embargo, como dice Bechtel, "los argumentos mentalistas desempeñan un papel tan central en nuestro pensamiento ordinario sobre nosotros mismos, así como en las teorías de las ciencias sociales, que parece imposible que podamos pasar sin ellos"58. Las explicaciones intencionales son centrales tanto en psicología como en las ciencias sociales, pero estas disciplinas serían imposibles como tales si el eliminacionismo o el reduccionismo tuvieran razón. Y aún más: sería difícil conciliar con estas posturas intuiciones más básicas aún, como la del libre albedrío de los seres humanos.

Podemos suponer una tesis acerca de la justificación de las teorías que prescribe asignar cierto peso a nuestras intuiciones. Las intuiciones y creencias de sentido común no tienen por qué ser un límite infranqueable para nuestras teorías -ni siquiera las intuiciones básicas-, pero tampoco pueden ser sencillamente ignoradas (especialmente las más básicas). Como diría Rescher, merecen respeto, aunque no necesariamente aceptación ${ }^{59}$. Sin embargo, las teorías que hemos examinado rechazan las intuiciones sobre lo mental con el argumento general de que no cuadran con la teoría, sin tratar de rechazarlas fundadamente. El argumento que se repite una y otra vez es que no caben en la teoría, pero eso - a falta de certeza acerca de la teoría- no es suficiente ${ }^{60}$.

${ }^{58}$ Bechtel [1991], pág. 141.

${ }^{59}$ Nicholas Rescher [1995], pág. 34.

${ }^{60}$ Existe otro argumento general contra los intentos eliminacionistas y reduccionistas de identificar los estados mentales con procesos cerebrales o neuronales y dar prioridad a los segundos frente a los primeros. Este argumento ha sido expuesto por von Wright señalando que lo mental tiene prioridad epistémica frente a lo neuronal. Supongamos que deseamos establecer cuál es el estado neuronal que se corresponde con el estado mental "estar asustado" en un determinado sujeto. Si queremos investigar esto, debemos saber previamente que el sujeto se encuentra asustado, con algún criterio independiente de sus estados neuronales (su conducta externa). De manera que aunque lo neuronal tuviera prioridad causal frente a lo mental, lo mental tendría prioridad epistémica frente a lo neuronal (y la conducta externa tendría, según von Wright, prioridad semántica frente a lo mental). Von Wright [1996]. 
Lo que debe hacerse, por tanto, es (1) buscar una concepción de lo mental que no abrace el dualismo de sustancias, pero que no niegue las propiedades de lo mental y (2) explicar las propiedades de lo mental en términos de fenómenos que emergen de lo físico (profundizando en tipos de relaciones como "emerger" o "supravenir"). En caso de que esto no sea posible, entonces tendremos que rechazar las propiedades mentales. Pero la discusión aún no está cerrada ${ }^{61}$.

\section{La negación de la intención (II): El argumento epistemológico}

1. Las consideraciones anteriores eran de tipo ontológico, pero también se puede rechazar la tesis de que probar las intenciones sea una tarea cognoscitiva con argumentos epistemológicos. Estos son más frecuentes entre los juristas ${ }^{62}$. Un argumento de este tipo es el que señala que los hechos psicológicos normalmente sólo pueden probarse mediante prueba indirecta y asigna a ésta una fiabilidad menor que a la prueba directa. Ya he considerado al comienzo este argumento. Otras veces los argumentos hacen referencia a ciertas peculiaridades de la prueba de las entidades mentales. Por ejemplo, los siguientes:

a) Los elementos subjetivos del delito deben probarse a partir de la conducta externa del individuo, pero ello exige la existencia de leyes que correlacionen la conducta externa con las entidades mentales. Sin embargo, si algo hemos aprendido del conductismo lógico, es que tales leyes son imposibles: un mismo estado mental puede corresponderse con un amplio abanico de acciones distintas (o con ninguna). A lo sumo, tenemos generalizaciones probabilísticas, pero no leyes estrictas ${ }^{63}$. Ahora bien, el argumento sería válido si sólo contáramos con generalizaciones inductivas acerca de la correlación entre conducta externa y estados mentales, pero, como trataré de mostrar más adelante, la prueba de la intención no sólo descansa en estas generalizaciones, sino también en la presunción de racionalidad del agente. Lo que nos permite atribuir una intención a un agente no es sólo el hecho de que el tipo de conducta que realizó es típica de cierta intención, sino el hecho de que esa conducta era racionalmente adecuada en la situación. En otras palabras: Sostener que entre un tipo de conducta y una determinada intención existe una correlación no es algo que aprendamos sólo por inducción a partir de observaciones anteriores. Probablemente es posible

\footnotetext{
${ }^{61}$ Una tesis que parece dar cuenta de algunas de estas intuiciones es el monismo anómalo de Davidson, (una variante de la tesis de la identidad de instancias), salvo por lo que respecta a la causalidad de lo mental. Manuel Liz [1995], pág. 216 y ss.

${ }^{62}$ Para una postura pesimista acerca de la prueba del dolo basada en una combinación de argumentos ontológicos y epistemológicos véase Paredes Castañón [2001].

${ }^{63}$ Puede encontrarse un argumento de este tipo en Ramón Ragués [1999], pág. 248 y ss.
} 
predecir aproximadamente la conducta de un individuo del que conocemos sus intenciones sin haber observado cómo actuaba anteriormente en otras ocasiones en que tenía las mismas intenciones. De manera que si conozco la conducta y las pautas del comportamiento racional, puedo inferir (aunque, por supuesto, no con certeza absoluta) su intención.

b) Otro argumento es el siguiente: Cuando atribuimos a una persona una determinada intención o un determinado conocimiento, en realidad estamos proyectando lo que creemos que nosotros hubiéramos querido o sabido en esas circunstancias. Estamos, por tanto, extrapolando nuestros potenciales estados mentales. Hacemos atribuciones intencionales a partir de nuestra propia evaluación de la situación, y esto siempre conlleva la posibilidad de error, debido a peculiaridades desconocidas del agente ${ }^{64}$. Este argumento, sin embargo, no tiene por qué llevar a negar la posibilidad de averiguar las intenciones de otros; sólo nos lleva a tratar de saber todo lo posible sobre el otro agente y a razonar no en función de nuestra evaluación de la situación, sino de la evaluación que creemos que el agente hubiera hecho. Lo que hay que hacer es usar criterios objetivos (esto es, que puedan ser aceptados por terceros y, por tanto, tengan fuerza argumentativa) pero adaptados al caso partircular. Por decirlo con palabras que George Fletcher usa para un supuesto semejante: nuestros criterios no deben ser subjetivos, sino individualizados ${ }^{65}$.

c) Otras veces el argumento viene a decir que el conocimiento de los hechos psicológicos es imposible porque, a diferencia de lo que ocurre con el resto de hechos, éstos no son comprobables una vez que se ha realizado la atribución. Sólo contamos con los criterios de atribución, y con ningún otro criterio de verificación. Este argumento me parece que es susceptible de dos objeciones: La primera es que sostener que un hecho sólo puede ser conocido si puede ser verificado directamente es una concepción ya superada de los hechos y de la epistemología; muchos de los hechos aceptados por los científicos (por ejemplo, ciertas partículas que se supone que componen el universo) no son verificables empíricamente de una forma directa, sino deducibles a partir del comportamiento de otros hechos y ciertas teorías. La segunda objeción es que, en la práctica, la mayor parte de los hechos que han de enjuiciarse en un proceso judicial no pueden ser verificados directamente, ya que ocurrieron en el pasado.

2. En general, el argumento a favor del carácter adscriptivo en sentido fuerte (atribución normativa) de las intenciones consiste en dar el siguiente paso: se niega que podamos tener certeza acerca de cuáles son los estados

\footnotetext{
${ }^{64}$ Ramón Ragués [1999], pág. 252.

${ }^{65}$ George Fletcher [1997], pág. 182.
} 
mentales de los demás (por alguna de las razones señaladas anteriormente o por otra distinta), y a partir de esta premisa (la falta de certeza) se concluye que las intenciones sólo pueden imputarse, no descubrirse. Me parece que éste es el razonamiento que hay detrás de las siguientes palabras de Kelsen:

“(...) cuando en el tipo de injusto parecen incorporarse requisitos como 'voluntad', 'intención' u otros fenómenos psíquicos, éstos deben simplemente interpretarse como factores externos que resulten recognoscibles de forma objetiva al juez y que admitan como posible la hipótesis de los fenómenos psíquicos en cuestión. Lo que el juez debe determinar en ciertos casos no es la verdadera voluntad o la verdadera intención que pertenecen al tipo de injusto -que en absoluto puede constatar-, sino que lo que debe determinar son circunstancias externas con base en las cuales el juez presume de forma jurídica determinados fenómenos psíquicos" ${ }^{\prime 6}$

La razón por la que Kelsen entiende que basta con que la situación permita "presumir de forma jurídica" (atribuir normativamente) las intenciones es que en absoluto se puede constatar la verdadera intención. Pero si este argumento se tomara en serio y se generalizara nos llevaría al siguiente dilema: O bien tendríamos que admitir que todo el conocimiento empírico depende de atribuciones normativas (porque la falta de certeza absoluta no sólo afecta a nuestro conocimiento de los estados mentales internos, sino a todo el conocimiento), lo cual es absurdo; o bien se restringe el alcance del argumento a los hechos psicológicos, lo cual parece injustificado, porque entonces se exige una certeza mayor sobre ellos que sobre los aspectos externos de la conducta.

Sin embargo, me parece que algunos juristas optan por esta segunda alternativa, y exigen mayor certeza a la prueba de hechos psicológicos que a la prueba de los elementos objetivos del delito. Creo que los siguientes ejemplos ponen de manifiesto esta actitud:

"Las dificultades acabadas de exponer hacen que cualquier afirmación sobre la existencia y características de los estados mentales de un sujeto resulte ser, en el mejor de los casos (esto es, en una situación experimental [y, por añadidura, en el proceso. DGL]), un mero caso de razonamiento abductivo o hipotético. Es decir, constituye únicamente la formulación de una hipótesis explicativa de un hecho - una conducta- que resulta compatible con las leyes explicativas aceptadas en Psicología. Pero, a falta de comprobaciones ulteriores, no garantiza la verdad de dicha hipótesis en el caso concreto"67

"De hecho, es perfectamente posible que, a la luz de los mismos indicios objetivos que el tribunal consideró relevantes en este caso para negar la existencia de dolo de homicidio, se pudiese demostrar que, pese a todo, sí que existía tal dolo" $"$.

\footnotetext{
${ }^{66}$ Kelsen, Hautprobleme, pág. 156. Tomo la cita de Ramón Ragués [1999], pág. 296.

${ }^{67}$ Paredes Castañón [2001], pág. 86.

${ }^{68}$ Paredes Castañón [2001], pág. 91.
} 
"Las reglas que sólo afirman bajo qué condiciones es probable un determinado conocimiento no cumplen con las condiciones de legitimidad exigidas por la concepción psicológica del dolo [esto es, la concepción que identifica el dolo con un estado mental. DGL], pues no permiten descartar que el caso que se enjuicia puede ser uno de los supuestos en que no existe de modo efectivo la realidad cuya existencia sólo se considera probable" ${ }^{" 69}$.

Sobre estas afirmaciones puede decirse lo siguiente: respecto a la primera, que toda inferencia probatoria -sea de hechos psicológicos o no- puede verse como una abducción o razonamiento hipotético (o como una inducción de algún tipo, o como una deducción a partir de una premisa mayor obtenida por inducción; en todo caso, siempre como un razonamiento que no garantiza la verdad material de la conclusión); respecto al segundo, que nunca podemos descartar totalmente la posibilidad de error judicial, tampoco para la prueba de los hechos externos; y respecto al tercero, que rara vez disponemos de máximas de experiencia que no sean probabilísticas. Entonces, ¿por qué hay que exigir más a la prueba del dolo que a la prueba de la autoría, por ejemplo, o de la relación causal? Por supuesto, en ambos casos hay que exigir un alto grado de certeza, pero en ninguno de los casos una certeza absoluta (ni siquiera tomando como paradigma de certeza absoluta la certeza científica). Si exigimos una certeza científica para los elementos objetivos del delito, nunca podremos probar nada. Y lo mismo ocurre con los elementos subjetivos. No hay que exigir menos para ellos, pero tampoco más.

\section{La negación de la intención (III): El argumento ideológico}

1. La última posibilidad de negar que las atribuciones de intención sean descriptivas que voy a examinar es de tipo ideológico. En rigor, lo que esta tesis sostiene es que estas atribuciones no deben o no tienen por qué ser descriptivas, no que no puedan serlo (si afirmaran esto último, se podrían reconducir a las de tipo ontológico o epistemológico).

Esta posición se vincula con tesis más generales acerca de la finalidad de la prueba. Algunas veces se niega que la prueba sea un instrumento de conocimiento de la verdad (o de la verdad como correspondencia con la realidad) y se la presenta como un instrumento de persuasión o convencimiento del juez (o para llegar a algún otro tipo de "verdad"). Estas tesis van unidas a una concepción del proceso como medio de resolución de conflictos, en donde no importa tanto la justicia de la decisión como alcanzar una solución ${ }^{70}$. El argumento, en definitiva, es que la verdad como correspondencia no importa

\footnotetext{
${ }^{69}$ Ramón Ragués [1999], pág. 249.

${ }^{70}$ Taruffo [2003], pág. 32.
} 
en el proceso y, por tanto, tampoco importa respecto de los hechos internos. Este argumento general puede ser refutado, como hace Taruffo, mostrando, por un lado, que la concepción persuasiva de la prueba es sólo una visión parcial del funcionamiento y los objetivos del proceso y señalando, por otro lado, la vinculación entre la justificación de la decisión judicial y la comprobación de que efectivamente se han producido los hechos que se describen en el supuesto de hecho de la norma (lo que requiere una teoría de la verdad como correspondencia en el ámbito de la prueba jurídica) $)^{71}$.

2. Desde el ámbito del Derecho penal existen algunos planteamientos que pueden conducir a posturas cercanas a éstas, aplicadas al caso específico del dolo. El punto de partida consiste en plantearse cuál es el fundamento de que las conductas dolosas merezcan una sanción mayor que las conductas imprudentes. Una posible respuesta es la aportada por Günther Jakobs, para quien la finalidad de la pena es lo que este autor llama prevención general positiva: "De acuerdo con la prevención general positiva la pena -a diferencia de lo que sucede con la prevención general negativa- no se dirige a la generalidad como si se tratase de un arsenal de futuros delincuentes potenciales a los que hay que intimidar. La pena se dirige al ciudadano fiel al Derecho (...) El contenido de la norma no lo conforma el que el autor no vuelva a delinquir en el futuro, ni mucho menos que nadie delinca, sino únicamente que es correcto confiar en la vigencia de la norma"72. En palabras de García Amado, quien expresa con suma claridad la idea de Jakobs:

"El delincuente expresa con su conducta que se guía por patrones diversos de los comunes, con lo que su modo de actuar no puede ser generalmente previsible y defrauda expectativas; el delincuente se comunica con sus semejantes en un registro diverso al de éstos, 'va por libre'. Y la pena expresa que los sujetos pueden seguir confiando en el registro establecido y común y que cuando una de sus expectativas de comportamiento ajeno se frustra no es porque estén en un error o porque las reglas comunes no sean tales, sino porque alguien se sitúa al margen de ellas deliberadamente. Pero hay que insistir nuevamente: no se trata de que con la pena se le reproche al delincuente su modo de ser o de actuar, la pena no pretende ni penetrar en su constitución individual ni cambiarla. El acto de comunicación que la pena supone no tiene como destinatario prevalente al delincuente, sino al conjunto de los ciudadanos que tienen ciertas expectativas, que la norma expresa, mostrándoles que están en lo cierto y que el defecto está en el actuar del otro"73

A la luz de este tipo de concepciones de la pena se puede sostener que los delitos dolosos merecen una pena mayor porque en ellos es más evidente

\footnotetext{
71 Taruffo [2003], págs. 39 y ss

${ }^{72}$ Günther Jakobs [1997], pág. 128.

${ }^{73}$ García Amado [2000], pág. 245.
} 
la decisión de infringir la norma (mientas que en los imprudentes esta decisión no es tan clara, sino que lo que hay es una evaluación errónea de la situación). Ahora bien, el hecho de que lo que importe no sea el reproche al individuo, sino fundamentalmente el "mensaje social" que transmite la pena, puede llevar a pensar que no importa si realmente el sujeto actuó dolosamente o no, sino que lo relevante es si el resto de la sociedad va a considerar que actuó dolosamente o no. Puesto que la pena es una manera de asegurar a la sociedad que la norma violada sigue vigente, no puede permitirse el caso de que la sociedad considere que una norma ha sido violada intencionalmente y no se siga la pena pertinente, con independencia de que hubiera intención real o no de violar la norma. Una sentencia en la que se declare que no se actuó intencionalmente no será comprendida si desde el punto de vista social todo apunta a que se había actuado intencionalmente. En palabras de Laurenzo Copello (refiriéndose específicamente a Puppe, pero con referencias también a Jakobs): "Lo importante, por consiguiente, de cara a determinar si se produce una contradicción con la norma jurídico penal, no son las actitudes internas del sujeto, sino lo que exprese la conducta desde la perspectiva de la comunicación entre seres inteligentes"74.

Sin embargo, este tipo de argumentos es susceptible de dos objeciones importantes. Primera: dependen de que no se le dé ningún valor al reproche como justificación de la pena, porque si éste tuviera algún valor, estaríamos asumiendo implícitamente que la intención que nos interesa es la real (como estado mental que causó la acción del sujeto). Y aunque puede quizá aceptarse que la explicación de la pena es la afirmación de la vigencia de la norma, la prevención general, positiva o negativa, o algún tipo de finalidad de este estilo, es difícil negar que la justificación de la misma se enraiza en las ideas de libre albedrío y reproche, que constituyen un presupuesto del sistema penal, y así se percibe incluso por la conciencia social a la que estas teorías aluden. Segunda: al reducir el concepto mental de intención a los criterios objetivos de atribución de intención, estos argumentos parecen confundir -como trataré de mostrar en el siguiente apartado-dos cuestiones distintas: (1) ¿en qué consiste "tener una intención”? y (2) ¿cómo sabemos

\footnotetext{
${ }^{74}$ Laurenzo Copello [1999], pág. 225. Este es el paso que parece dar también Ramón Ragués (aunque no sólo por razones ideológicas; también usando el argumento epistemológico), cuando afirma que "el recurso al sentido social implica que la consideración de una conducta como dolosa ya no depende de determinados datos psíquicos cuya aprehensión resulta imposible, tanto para el juez como para los ciudadanos, sino de que dicha conducta, de acuerdo con sus características externas y perceptibles, se valore socialmente como negación consciente de una concreta norma penal”. Ramón Ragués [1999], pág. 324. Un argumento similar es que la sentencia debe ser entendida, por lo que lo importante es adecuar sus resultados a la conciencia social. Esto nos lleva a que hay dolo cuando lo hay de acuerdo con la convicción social, y no cuando lo tiene realmente el sujeto.
} 
qué intención tiene un agente? Esto es, confunden el significado de "intención" con los criterios de averiguación de la intención. Por eso estos autores pueden afirmar que "Existe dolo cuando, a partir del sentido social de un hecho y de las circunstancias que lo acompañan, puede afirmarse de modo inequívoco que un sujeto ha llevado a cabo un comportamiento objetivamente típico atribuyéndole la concreta capacidad de realizar un tipo penal"75.

\section{VII. ¿En qué consiste en realidad ser adscriptivista?}

1. Quienes, desde el ámbito del Derecho, niegan de una u otra manera la existencia de la intención, la posibilidad de conocerla o la conveniencia de descubrirla suelen argumentar a favor de imputarla. Podemos llamar a estos autores adscriptivistas (en sentido fuerte), y a los que consideran que la prueba de la intención es una cuestión de atribuciones teóricas (descriptivas), los podemos llamar "descriptivistas". Otras veces las etiquetas son distintas (or ejemplo: concepciones normativas frente a concepciones psicológicas del dolo), pero el problema es el mismo.

Los criterios de imputación que suelen proponer los adscriptivistas suelen ser presunciones procesales o reglas de experiencia de aceptación generalizada en la sociedad. ¿Podrían ser criterios arbitrarios?

Supongamos que decidimos que si la acción se realizó en días pares, consideraremos que la intención era la de producir el daño mayor (en el ejemplo con el que comenzábamos, animus necandi), y si se realizó en días impares, la intención de producir el daño menor (en nuestro ejemplo, animus laedendi); pero eso sólo entre semana: si se realizó en fin de semana, decidimos que el delito no fue intencional. De esta forma, satisfacemos un fin importante: logramos un criterio objetivo ( $\mathrm{y}$ sin apenas margen de error) para determinar si se dieron o no los elementos subjetivos que el tipo penal exige. Además, podríamos afirmar -como hacen algunos adscriptivistas- que la intención consiste en la situación en la que un agente se encuentra cuando de acuerdo con las reglas de atribución se le va a atribuir una determinada intención. ¿Es esta una posición aceptable? Es bastante obvio que pocos adscriptivistas aceptarían criterios arbitrarios. Pero, ¿por

\footnotetext{
${ }^{75}$ Ramón Ragués [1999], pág. 521. 3. En otras ocasiones, el argumento ideológico contra la prueba de la intención consiste en reducir el concepto de dolo a las actitudes epistémicas del sujeto que actúa (por ejemplo, Laurenzo Copello [1999], cap. IV; Ramón Ragués [1999]). La cuestión es si para determinar si un agente tenía la intención de hacer $X$ basta con mostrar que hizo $Y$ siendo consciente de que con ello daría lugar a $X$ (por supuesto, aquí cabe graduar la creencia, según que se pensara que el resultado se produciría necesariamente o con un grado mayor o menor de probabilidad). Se despoja, por tanto, al dolo de los aspectos volitivos, pero el problema de la posibilidad o conveniencia de conocer los hechos psicológicos permanece exactamente igual, aunque referido a las creencias en lugar de a los aspectos volitivos.
} 
qué? No porque de esta manera no se logre satisfacer ningún fin importante (que sí se logra). Parece absurdo porque con criterios arbitrarios no estamos atribuyendo intenciones ni nada que se le parezca. La mayoría de los adscriptivistas dirían que los criterios de atribución deben ser razonables, y esto sólo puede ser entendido en el sentido de que deben reducir el margen de error. Incluso el criterio del sentido social de la intención es un medio de reducir el margen de error.

Lo que quiero sugerir aquí es que la contraposición entre adscriptivistas y descriptivistas, o entre teorías normativas y teorías psicológicas del dolo o la intención, es en una buena mayoría de casos una distinción falsa, que sólo apunta a diferencias de énfasis. Un test para "descubrir" al adscriptivista convencido puede consistir en preguntarle si piensa que las reglas de atribución son o no derrotables por consideraciones relacionadas con su correspondencia con los estados mentales. Si opina que no, entonces es realmente adscriptivista, pero en caso contrario sus atribuciones son esencialmente teóricas. Aunque pudiéramos conocer infaliblemente las intenciones reales, como estados mentales, con alguna máquina de ciencia ficción, el adscriptivista todavía tendría que defender que la intención que se imputa en el proceso no tiene por qué coincidir con los informes de la máquina. Esta postura sólo podría sostenerse por razones ideológicas, pero me parece muy difícil de legitimar, y mucho menos extendida de lo que pueda parecer leyendo las discusiones sobre el tema.

Lo que en realidad buscan la mayoría de los que se consideran adscriptivistas no es imputar la intención con total desconsideración de la realidad, sino legitimar de alguna manera el margen de error que siempre existe cuando atribuimos intenciones. Pretenden afirmar que incluso habiendo posibilidad de error es legítimo atribuir una intención. Pero lo mismo puede decirse de cualquier otro tipo de hecho que sea necesario probar. La prueba no es nunca un instrumento que permita una certeza absoluta; sin embargo, está justificado usarla. Pero está justificado precisamente en la medida en que se oriente a la verdad de los hechos. Lo contrario es sustituir la verdad material por la verdad formal como objetivo del proceso, sea a propósito de hechos externos, de la causalidad o de los hechos psicológicos.

Por supuesto, eso no excluye que probar la intención sea una atribución con fines prácticos; que la hagamos usando reglas generales (pero no arbitrarias, sino con fundamento inductivo); que en casos dificiles, donde las reglas no dan una solución clara, debamos decidir entre varias alternativas (pero asignando un peso a las pruebas y a las reglas, no en función de intereses distintos de la búsqueda de la verdad); que podamos equivocarnos y que sea revocable (precisamente por ello). Pero estas cosas no le quitan carácter teórico a la atribución. La prueba de los hechos psicológicos es más 
difícil, pero no es esencialmente distinta de otras pruebas indirectas sobre hechos externos ${ }^{76}$.

2. Creo que las razones anteriores son suficientes para aceptar que la atribución, tanto en los casos de prueba de la intención como en los supuestos de explicación intencional de una acción, es una atribución teórica. Esto nos permite tratar la prueba de la intención como un razonamiento similar a la explicación intencional de la acción. Tanto en uno como en otro caso, lo que ha de hacerse es encontrar la intención que el agente realmente tenía al actuar. Me parece que para ello es también fundamental recurrir a un Principio de Racionalidad. Los modelos de explicación intencional que hemos analizado en el apartado II recurrían a la presunción de racionalidad (de acuerdo con la cual siempre actuamos conforme a nuestras decisiones fruto de nuestra evaluación de la situación) para justificar el paso de las intenciones a la acción efectivamente realizada. La atribución de intención sería una fase previa a la descrita en estos modelos. Lo que quiero sugerir es que también en esta fase previa necesitamos un principio de racionalidad.

\section{Intención y racionalidad}

1. Podemos distinguir dos tipos de acciones: las acciones expresivas y las dirigidas a fines. Las primeras son expresiones de alguna emoción o algún estado de ánimo, que las causa. Por ejemplo, es posible que si estoy sentado esperando nervioso algún acontecimiento importante en mi vida, de repente me levante y me ponga a pasear y silbar por la habitación, sin haberlo decidido. O si en medio de una discusión acabo enfadándome es posible que empiece a manotear. Se trata de acciones que expresan algún estado de ánimo, pero sin que yo me haya propuesto expresarlo. ¿Son acciones intencionales? Yo podría hacerlas intencionalmente, y podría aprender a evitarlas; es decir, en mayor o menor medida, puedo controlarlas. Si me doy cuenta de que me voy a levantar y ponerme a silbar, puedo evitarlo. Además, mientras las estoy haciendo, o cuando alguien me pregunta qué estoy haciendo, soy consciente de ellas (en el sentido de que tengo una certeza no basada en la observación de mi conducta externa de lo que estoy haciendo). Sin embargo, no puedo dar una razón (finalista, no meramente causal) de por qué las estoy haciendo. Todo esto nos autoriza a decir que son intencionales, pero en un sentido mínimo o débil. A veces expresamos lo mismo diciendo que son voluntarias, para distinguirlas de los meros actos reflejos, que no podemos controlar (podemos quizá reproducirlos, pero no evitarlos).

Las acciones dirigidas a fines son intencionales en un sentido más fuerte. Se dirigen a algo; en ellas intervienen deseos y creencias acerca de cómo

\footnotetext{
${ }^{76}$ Perfecto Andrés Ibáñez [1992], pág. 269.
} 
satisfacerlos. En algunos casos, el carácter intencional de estas acciones es más evidente, porque son el resultado de una decisión razonada: Deliberamos acerca de qué fines perseguir (aunque fuera cierto que los fines últimos vienen impuestos por las pasiones, como pensaba Hume, podemos decidir no entregarnos a alguna pasión o no perseguir fines incompatibles, o priorizarlos ${ }^{77}$ ) y cuáles son los medios adecuados para alcanzarlos. Otras veces realizamos una conducta dirigida a un fin sin que hayamos deliberado previamente y sin haber decidido, en ese momento, hacerla; aun así, también estas acciones son intencionales: queremos el fin y queremos la acción como un medio para conseguirlo. Cuando salgo de mi casa por las mañanas y conduzco hasta la universidad, realizo muchas acciones de este tipo (darle la vuelta a la llave de casa, andar, arrancar el coche, insertar la primera, poner el intermitente, mirar por el retrovisor, etc., etc., etc.). Aunque no sean el resultado de una decisión en cada momento previo a su realización, son el producto de un proceso de aprendizaje o de surgimiento de un hábito, y si retrocedemos en el tiempo a lo largo de ese proceso, acabamos encontrando en su origen un esfuerzo para realizarlas y, probablemente, una decisión.

¿Puede haber acciones intencionales en un sentido fuerte que no se dirijan a ningún fin? Mosterín habla de acciones que tienen ellas mismas un sentido final o de fin: no las realizo para obtener un fin distinto, sino que ellas mismas son el fin que persigo ${ }^{78}$. Por ejemplo, cantar por cantar o leer un libro por placer. Sin embargo, podemos decir (aunque resulte un poco artificioso) que también estas acciones persiguen un fin: satisfacer mi deseo. Deseo (porque me apetece) cantar y sé que la mejor manera de satisfacer mi deseo es ponerme a cantar. Las trataré, por tanto, como acciones dirigidas a fines (no obstante, es importante retener que no siempre que hacemos algo intencionalmente perseguimos un fin distinto a la mera realización de la acción intencional) ${ }^{79}$.

Podemos dejar de lado en nuestra discusión las acciones que he llamado expresivas. A efectos de una teoría de la prueba, lo que hay que reconocer en ellas es que son intencionales, aunque en sentido mínimo, por lo que pueden generar responsabilidad si dan lugar a consecuencias lesivas para algún interés, pero esas consecuencias no serán ellas mismas intencionales. Cuando una acción es de este tipo, su intencionalidad no se transmite a las

${ }^{77}$ Sobre en qué sentido se puede hablar de racionalidad de fines véase Rescher [1993], pág. 112 y von Wright [1986].

${ }^{78}$ Mosterín [1987], pág. 193.

${ }^{79}$ Por otra parte, cuando estas acciones tienen consecuencias lesivas o perjudiciales para terceros -cuando alguien roba por robar o mata por matar- tendemos a considerarlas patológicas en algún sentido y, por tanto, no intencionales o con una intencionalidad viciada. 
consecuencias. ¿Cómo podemos distinguir entre las acciones expresivas que son efectivamente intencionales y los actos reflejos? Simplemente tratando de averiguar sus causas y, en función de ellas, si el agente pudo evitar actuar o no.

Me centraré, por tanto, en las acciones que realizamos con una intención u objetivo.

2. Entre la noción fuerte de intención y el concepto de racionalidad existe una estrecha conexión. Que existe esta conexión es algo obvio, pero cuál es su alcance puede ser algo más difícil de establecer.

Actuar con una intención es actuar persiguiendo un fin. Podemos decir que procurar ese fin es la razón de nuestra acción ${ }^{80}$. Por tanto, podemos asumir la siguiente definición: $X$ hace $A$ con la intención de dar lugar a $F$ si cree que $A$ es un medio para dar lugar a $F$ y hace $A$ por esa razón. Actuar intencionalmente también se puede definir como actuar por una razón (instrumental).

Por otra parte, actuar racionalmente es algo que también podemos definir en términos de razones. Así, de acuerdo con Rescher, "actuar racionalmente" puede definirse con la siguiente fórmula ${ }^{81}$ :

$X$ hace $A$ racionalmente $=$

1. $X$ hace $A$.

2. $X$ tiene arrolladoramente buenas razones para hacer $A$

3. $X$ hace $A$ apoyándose en esas razones.

Arrolladoramente quiere decir que las razones para hacer esa acción son mejores que las razones para hacer otra distinta o ninguna en absoluto. Actuar racionalmente, por tanto, implica actuar por una razón, esto es, intencionalmente. Toda acción racional es intencional. Lamentablemente, en este sentido de racionalidad, no puede decirse lo contrario: No siempre que actuamos intencionalmente tenemos mejores razones para haber hecho esa acción que otra o ninguna.

3. La racionalidad a la que hace referencia la definición anterior es una racionalidad fuerte y objetiva. Sólo actuamos racionalmente si actuamos por razones objetivamente buenas. Pero podemos distinguir tres supuestos:

a) Que las razones por las que $X$ efectivamente actuó fueran objetivamente buenas razones.

b) Que las razones por las que $X$ efectivamente actuó fueran, para él (en su opinión), buenas razones.

\footnotetext{
${ }^{80}$ La noción de razón para la acción es enormemente complicada y no puedo entrar aquí a analizarla. Usaré la expresión en un sentido muy amplio y casi de "lenguaje común". Pueden encontrarse análisis en profundidad de esta noción en Juan Carlos Bayón [1991] y Cristina Redondo [1996].

${ }^{81}$ Rescher [1993], pág. 25.
} 
c) Que las razones por las que X efectivamente actuó fueran las que, en el momento de actuar, le parecieron buenas razones.

A partir de aquí podemos introducir las siguientes definiciones:

a) Racionalidad perfecta: Un agente actúa de manera perfectamente racional cuando lo hace movido por razones objetivamente buenas. En el momento de actuar, lo que consideró buenas razones lo eran objetivamente (esto es, para cualquier ser racional). Estas razones objetivamente buenas no sólo explican mi acción (si efectivamente se actuó por ellas, y no sólo conforme a ellas), sino que además la justifican ${ }^{82}$.

b) Racionalidad imperfecta: Un agente actúa de manera imperfectamente racional cuando lo hace movido por las razones que a él le parecen buenas, si éstas no coinciden con las objetivamente buenas. Se trata de razones que le parecerían buenas a cualquier persona como él, pero no a toda persona racional. Por ejemplo, si deseo ir a Barcelona en tren en lugar de tomar el avión porque soy supersticioso y tengo que viajar en martes 13, mis razones serán buenas para mí (y los supersticiosos), pero no son objetivamente buenas. Sin embargo, dado que hay una coherencia entre mis creencias generales y mis acciones, podemos hablar de algún grado de racionalidad. Estas razones no justifican objetivamente mi acción (aunque la justifiquen para $m i$ ), pero sí la explican.

b) Racionalidad mínima: un agente actúa de manera mínimamente racional cuando lo que creyó en el momento de actuar que eran buenas razones no lo eran objetivamente, y además tampoco coincidían con lo que en condiciones normales él mismo hubiera considerado buenas razones. Se trata de supuestos de error en la ocasión concreta en que se actuó por falta de deliberación, urgencia de actuar, defectuosa interpretación de las circunstancias, uso de información no fiable, desprecio de información relevante, exceso de emotividad, etc. Pero incluso en estos casos hubo cierta coherencia entre mis creencias efectivas en el momento de actuar y mi acción: ésta se ajustó a razones, aunque fueran equivocadas. También estas razones explican mi acción, aunque no la justifiquen.

Creo que el siguiente pasaje de John Watkins, aunque largo, puede contribuir a aclarar qué entiendo por racionalidad mínima (que él llama racionalidad imperfecta):

"Al conjunto de todas aquellas consideraciones que, se formulen o no conscientemente, entran en un caso particular de toma de decisión lo llamo 'esquema

\footnotetext{
${ }^{82}$ Construir un modelo de explicación intencional de la conducta a partir de un Principio de Racionalidad Perfecta reduce las acciones explicables a las acciones racionalmente justificadas, lo que deja fuera, quizá, a la mayoría de acciones intencionales (pues no toda acción intencional es objetivamente racional). Para una crítica a las concepciones que adoptan este principio fuerte, véase Amparo Gómez Rodríguez [1997].
} 
de decisión'. Según la teoría normativa de la decisión, un esquema de decisión debe consistir en una especificación completa de valores de retribución a los resultados posibles, un mapa de preferencias completo o una asignación completa de valores de retribución a los resultados, y (en los casos en que resulta adecuado) un sistema para hacer frente a los diversos riesgos e incertidumbres.

Si se le juzga por esto, un esquema de decisión real es usualmente algo verdaderamente muy imperfecto. Un esquema de decisión ideal se describe como algo que la mente del agente tiene presente en su totalidad, un todo completo en el que los varios componentes juegan simultáneamente su papel oportuno. Un esquema de decisión real se construye generalmente parte a parte, de manera que la llegada de una parte aislada de información situacional puede tener una influencia totalmente desproporcionada. E incluso cuando estén incluidos todos los datos, la significación práctica de las diferentes partes del mismo puede crecer o disminuir a medida que el que ha de tomar la decisión atiende ora a un factor, ora al otro.

No solamente es un esquema de decisión real más o menos vago y fragmentario cuando se le compara con el ideal, sino que el agente lo reducirá y simplificará aún más a medida que se acerca una decisión. En lugar de la enumeración completa de las posibilidades que exige la teoría normativa, nos fijamos en unas cuantas características y elegimos algunas posibilidades interesantes de la situación-problema dada" 83

Ya hemos visto que no puede decirse que todas las acciones intencionales sean perfectamente racionales. Tampoco podemos decir que siempre sean imperfectamente racionales (puede haber errores). ¿Podemos decir al menos que son mínimamente racionales? Para llegar a esto todavía tenemos que hacer una restricción más.

4. Como sabemos, la racionalidad puede ser de fines o instrumental. Creo que debemos admitir que no siempre actuamos persiguiendo lo que creemos, en un momento concreto, que son los mejores fines, los más adecuados o los que más nos convienen. A veces -muchas veces- actuamos siendo conscientes de que nuestros fines no son los que debemos perseguir. "Demasiado a menudo - dice Rescher- los deseos y apetitos nos guían en lo que hacemos, y éstos pueden ser o no buenos consejeros con respecto a la racionalidad (...) Los individuos automáticamente tienen un motivo cuando se presenta un deseo, pero sólo tienen buenas razones cuando evidentemente hacen algo de acuerdo con su mejor interés" ${ }^{84}$. De manera que, aceptado esto y dejando de lado por tanto la racionalidad de fines, lo que nos queda de la pregunta anterior es lo siguiente: ¿siempre que actuamos intencionalmente soy al menos mínimamente racional desde el punto de vista instrumental,

\footnotetext{
${ }^{83}$ John Watkins [1982], pág. 127.

${ }^{84}$ Rescher [1993], pág. 19.
} 
esto es, me muevo para satisfacer un deseo y elijo los medios que me parecen más adecuados en ese momento para satisfacerlo?

Creo que la respuesta es necesariamente afirmativa. Es una cuestión conceptual que cuando actúo con la intención de dar lugar al fin $F$ realizo la acción que en ese momento me parece más adecuada (teniendo en cuenta mis posibilidades, mis preferencias, mis meros "gustos" y mi evaluación de la situación) para lograr $F$. En eso consiste actuar intencionalmente. Obsérvese que no se trata de elegir una acción adecuada cualquiera, sino la que considero la más adecuada. Si elijo una acción que puede contribuir al resultado, pero no es la más adecuada, y no puedo aducir ninguna razón o preferencia para haberla escogido (en un sentido muy amplio, que puede incluir el mero hábito), ningún observador dirá que tuve la intención de producir $F$ con mi acción (salvo que se convenza de que hay alguna razón oculta para mi preferencia); y yo mismo no podré decirlo seriamente. De manera que la racionalidad que encontramos en todas las acciones intencionales es una racionalidad instrumental mínima, lo que implica que cuando hacemos una acción intencional consideramos que tenemos una buena razón (instrumental) para hacerla. Llamaré a esta conexión entre acción intencional y racionalidad Principio de Racionalidad Mínima (PRM) ${ }^{85}$.

\section{Apuntes para un modelo de prueba de la intención}

1. En el esquema de decisión que precede a muchas de nuestras acciones intencionales juega un papel importante el medio social en el que la acción va a realizarse. Lograr nuestros objetivos requiere en muchas ocasiones contar con la existencia de otros sujetos (entonces podemos hablar de nuestra acción como acción social ${ }^{86}$ ). Nuestra evaluación de la situación debe tener en cuenta no sólo la existencia de tales sujetos, sino también su calidad de agentes que se mueven persiguiendo sus propios objetivos. Las acciones de los demás son importantes para nosotros si queremos coordinarnos con ellos, colaborar, competir o simplemente evitar sus interferencias. Para todo ello necesitamos atribuir intenciones a los demás, y es algo que hacemos cotidianamente.

Un gran número de estas atribuciones son exitosas, en el sentido de que logramos ajustar nuestra conducta a la de los demás y conseguir de esa

\footnotetext{
${ }^{85}$ Amparo Gómez Rodríguez define lo que llama el Principio de Racionalidad Mínima como no actuar inconsistentemente. Gómez Rodríguez [1992], pág. 129. En un sentido semejante, Salvador Giner escribe que "la acción humana es racional. Lo es en el sentido, y sólo en el sentido, de que persigue fines deseados por los sujetos según sus intenciones, recursos y creencias. Para ello los sujetos eligen, en todo tiempo y lugar, la senda disponible que juzgan más adecuada a ellos y a los recursos a su alcance”. Salvador Giner [1997], pág. 112.

${ }^{86}$ Salvador Giner [1997], pág. 40.
} 
manera nuestros objetivos ${ }^{87}$. Si falláramos demasiado a menudo la vida en sociedad sería imposible y las más de las veces no alcanzaríamos nuestros objetivos (no sólo los objetivos colectivos, sino tampoco la mayoría de los individuales). Esta fiabilidad "en general" permite tener cierta confianza en nuestros criterios y procedimientos de atribución de intenciones y en nuestra manera de entender los conceptos involucrados (como el de intención), justificándolos desde un punto de vista práctico ${ }^{88}$. Además, este tipo de justificación se basa en la experiencia y es de carácter inductivo: si en el pasado los criterios que uso para atribuir intenciones me han resultado generalmente provechosos no tengo razones para pensar que no vayan a seguir siéndolo en el futuro (aunque en casos concretos puedan conducirme a errores). Los criterios y el procedimiento de atribución no tienen por tanto un origen normativo en el mismo sentido en que lo pueden tener los criterios de atribución de responsabilidad moral o jurídica, por ejemplo (lo que, de nuevo, diferencia a las atribuciones de intención de las imputaciones en sentido estricto).

Ahora bien, como ocurre con muchas otras capacidades, podemos atribuir intenciones con cierta fiabilidad, pero es más fácil hacerlo que decir cómo lo hacemos. Normalmente captamos el sentido de una acción (por qué la realizó el agente) sin esfuerzo, como entendemos el significado de una proferencia ${ }^{89}$. Si sólo nos interesaran las atribuciones de intenciones como punto de partida para la explicación de la acción, quizá podríamos detenernos aquí. Pero si lo que queremos son guías útiles para la prueba de la intención (y para la motivación de la valoración de la prueba), no continuar equivaldría a dejar la cuestión en manos del convencimiento subjetivo del juez. El juez tiene, como todos, la aptitud de atribuir intenciones (aunque debe hacerlo con la dificultad añadida de no haber presenciado directamente la acción), pero debe además justificar la atribución. Por ello hay que exa-

\footnotetext{
${ }^{87}$ De acuerdo con la hipótesis del animal maquiavélico, desde un punto de vista evolutivo la necesidad de reconocer los estados mentales de otros para adaptar la conducta propia y manipular la ajena en función de ellos fue fundamental para el desarrollo de la inteligencia y la racionalidad humana. Fernando Broncano [1995], pág. 320 y 321.

${ }^{88}$ El criterio fiabilista o pragmático ha sido usado como criterio para justificar el conocimiento científico y la racionalidad epistemológica. Véase, por ejemplo, Rescher [1993], págs. 55 y ss. Para una aplicación del criterio al campo de la racionalidad práctica y evaluativa puede verse Fernando Broncano, [1995], págs. 326 y ss.

89 “Cabría decir que la conducta intencional se parece al uso del lenguaje. Es un gesto por el que doy a entender algo. De la misma manera que el uso y la comprensión del lenguaje presupone una comunidad lingüística, la comprensión de la acción presupone una comunidad de instituciones, prácticas y aparato técnico, en la que uno llega a introducirse mediante aprendizaje y entrenamiento". Von Wright [1987], pág. 139.
} 
minar nuestros procesos de atribución y explicitar los criterios en la medida de lo posible.

2. La inferencia práctica y los modelos de Hempel y Popper que hemos visto en el apartado II parten de las intenciones y creencias del agente y concluyen la acción a partir de ellas. El razonamiento con el que tratamos de probar la intención de un agente, por el contrario, parte de la descripción de su conducta externa - conducta a la que presume intencional ${ }^{90}$ - y trata de inferir la intención a partir de ella y las creencias del mismo:

(1) $A$ creía que $p$ es el medio más adecuado para dar lugar a $F$.

(2) $A$ hizo $p$

(3) $A$ tenía la intención de dar lugar a $F$ al hacer $p$.

Retomando el ejemplo con el que comenzábamos:

(1) Alfredo sabía que disparar un arma en tales y cuales circunstancias era una manera adecuada de matar a Herminio.

(2) Alfredo disparó en esas circunstancias

(3) Alfredo disparó con el fin de matar a Herminio (esto es, tenía la intención de matar a Herminio).

Aparentemente, este argumento es una inferencia práctica "del revés". Pero en realidad no es así. La inferencia práctica y los modelos de otros autores tienen como conclusión una acción ya interpretada intencionalmente, mientras que el punto de partida de la inferencia que trata de atribuir una intención es una acción que todavía no ha sido interpretada (se le presume intencional, pero todavía no se le ha asignado ningún contenido a esa intención). En otras palabras: la inferencia que atribuye una intención toma como premisa sólo el aspecto externo de la acción. Determinar con qué intención se realizó consiste en interpretar intencionalmente la secuencia de movimientos corporales observada, esto es, en pasar de lo que en otro lugar he llamado "acto-básico" a una acción interpretada a la luz de las intenciones del agente ${ }^{91}$.

${ }^{90}$ El punto de partida de nuestro proceso de atribución de intenciones es la presunción de que la acción que observamos es intencional. Ante las acciones de otros agentes adoptamos prima facie lo que Denett llamaba la actitud intencional. Sólo en caso de que no logremos encontrar ninguna explicación intencional satisfactoria de la acción (o que las excusas aducidas excluyan la posibilidad de esa explicación) la consideraremos una acción no intencional.

${ }^{91}$ Cada vez que actuamos podemos distinguir (1) ciertos movimientos corporales (actobásico), (2) lo que hacemos intencionalmente al realizar tales movimientos corporales (acto-resultado) y (3) las consecuencias socialmente relevantes de (2) (acto-consecuencia). A propósito 
La atribución de una intención requiere, por tanto, una descripción detallada de los aspectos externos de la conducta y de sus circunstancias; una descripción todavía no interpretada. Una manera de expresar esto es afirmar que la conducta externa es "síntoma" de la intención. Nuestra experiencia nos permite correlacionar tipos de conducta externa y tipos de estados mentales y probablemente usamos estas máximas de experiencia en nuestras atribuciones cotidianas de intención, razonando por analogía.

Podemos también atribuir intenciones antes de que la acción sea realizada, pero entonces tenemos que basarnos en las "conductas preparatorias". La atribución de intención es más difícil en este supuesto que cuando la acción ya ha tenido lugar ${ }^{92}$, porque no podemos examinar para qué fines era adecuada tal acción.

3. Lo que nos permite pasar de la descripción de la acción a la atribución de intención no es sólo nuestro conocimiento de las correlaciones frecuentes entre tipos de conducta externa y estados mentales. Si fuera así, sólo podríamos atribuir intenciones en los supuestos en los que efectivamente tenemos suficientes experiencias anteriores. El PRM cumple un papel fundamental en nuestras atribuciones de intenciones y puede ser aplicado a supuestos en los que carecemos de experiencia, si al menos conocemos los medios causalmente adecuados para alcanzar fines naturales y los medios convencionalmente adecuados para alcanzar fines institucionales.

De acuerdo con este principio, cuando los agentes realizan intencionalmente una acción, consideran que tienen una buena razón desde un punto de vista instrumental para hacerla, esto es, consideran que esa acción es el mejor medio de dar lugar al fin que persiguen (o al menos el medio que prefieren). De manera que un examen de para qué fin es adecuada la acción realizada nos ofrece una hipótesis acerca de cuál era la intención del agente.

Volvamos al ejemplo del comienzo. ¿Cómo sabemos que Alfredo disparó con la intención de matar a Herminio, y no meramente de lesionarle? La respuesta es que los sujetos procuran realizar la acción que, a su juicio, tiende a asegurarles el resultado que pretenden y la acción de Alfredo fue instrumentalmente adecuada para matar a Herminio (como sabemos por el

\footnotetext{
de la conveniencia de distinguir estas tres dimensiones en el concepto de acción véase Daniel González Lagier [2001], págs. 109 y ss.

${ }^{92}$ Quizá esto explique la asimetría que von Wright ha observado entre predecir una acción antes de que tenga lugar y explicarla.Véase von Wright [1983], pág. 59. Recoge también esta intuición Juan Carlos Bayón [1991], pág. 49. La explicación de la asimetría consistiría en que tanto para predecir la acción como para explicarla necesitamos atribuir al agente una intención, pero resulta más difícil atribuir la intención si la acción todavía no ha tenido lugar que si podemos examinar su adecuación instrumental a ciertos fines.
} 
calibre de la escopeta usada, el lugar del cuerpo de Herminio hacia donde apuntó, la distancia, etc.).

El razonamiento completo sería el siguiente:

(1) Los agentes realizan la acción que creen más adecuada para lograr el fin que persiguen (PRM).

(2) Alfredo creía que la manera más adecuada de matar a Herminio consistía en disparar en las circunstancias $\mathrm{C}$

(3) Alfredo disparó en las circunstancias C

(4) Alfredo disparó intencionalmente, esto es, con un fin ulterior (presunción de intencionalidad).

(5) Alfredo disparó con el fin de matar a Herminio (esto es, tenía la intención de matar a Herminio).

4. El razonamiento anterior no es deductivo, sino, como suele ocurrir en los casos de prueba, inductivo o hipotético. La conclusión, por tanto, no es necesariamente verdadera, pero sí razonable a la luz de las premisas. Es lógicamente posible que Alfredo quisiera meramente lesionar a Herminio, aunque le apuntara al corazón. Pero es poco probable. Para aumentar nuestra confianza en este argumento debemos someterlo a ciertos requisitos:

a) Debemos comparar la conclusión del argumento con otras hipótesis alternativas que también puedan explicar la acción. Esto es, debemos comparar la hipótesis "Alfredo disparó con el fin de matar a Herminio" con otras posibles explicaciones de por qué disparó. Aquí los argumentos basados en la coherencia de la narración de los hechos son relevantes para seleccionar la hipótesis más sólida. Por ejemplo, no parece creíble que Alfredo disparara al corazón si sólo quería lesionar o asustar. Puede ser fundamental también examinar si el medio empleado era sólo adecuado para un fin o para varios (aunque lo fuera en menor medida), si era condición necesaria, suficiente o meramente contribuyente del fin, etc.

b) Debemos examinar si hay otras razones (además de la adecuación instrumental de la acción) que confirmen la hipótesis. Por ejemplo, el PRM no sólo nos dice que si el agente disparó lo hizo con algún fin, sino que también nos dice que si el fin era matar, el agente debía tener a su juicio alguna buena razón para matar. La conducta anterior y posterior del sujeto puede constituir indicios de esto. Por ejemplo, las discusiones anteriores entre Alfredo y Herminio pueden apuntar a que Alfredo tenía razones (motivos) para matar a Herminio.

5. También podemos servirnos en nuestras atribuciones de intenciones de cierta "lógica de la intención" derivada igualmente del PRM. Algunos de sus principios podrían ser los siguientes: 
a) Si un agente tiene la intención de hacer $\mathrm{A}, \mathrm{y} \mathrm{B}$ es incompatible con A, no tiene la intención de hacer B (Principio de no contradicción de las intenciones).

b) Si el agente cree que la acción B se sigue necesariamente de la acción A, no puede tener la intención de A y no tener la intención de B (Principio de transmisión de la intención a las consecuencias necesarias o previsibles).

c) Si el agente tiene la intención de hacer $\mathrm{B}$ y cree que A es el único medio para dar lugar a B, tiene también la intención de hacer A (Principio de transmisión de la intención a los requisitos causales o convencionales).

6. En el razonamiento con el que atribuimos intenciones necesitamos hacer referencia a las creencias del agente. Esto puede hacer pensar que hemos pasado del problema de atribuir intenciones al problema, igualmente difícil, de atribuir creencias. Sin embargo, esto es inevitable, como hemos aprendido del conductismo. Dado el "holismo de lo mental", es imposible definir un estado mental sin referencia a otro.

En todo caso, quizá pueda pensarse que es más fácil atribuir creencias que intenciones, en el sentido de que son más obvias las máximas de experiencia que usamos. Ramón Ragués sugiere (entre otras) las siguientes:

a) La consideración de una persona como imputable lleva a atribuir a un sujeto todos aquellos conocimientos cuya ausencia sólo se entiende posible en quien padece algún tipo de perturbación psíquica o sensorial, o en menores de edad.

b) El hecho de que una persona haya sido normalmente socializada hace que se le puedan atribuir todos aquellos conocimientos cuya ausencia sólo se concibe en sujetos que no han tenido contacto con la civilización de la que se trate.

c) La circunstancia de que en un sujeto concurran determinadas características personales o de que ocupe una determinada posición social lleva a imputarle los conocimientos cuya ausencia haría impensable que tuviera esas características o que ocupara tal situación. ${ }^{93}$

No obstante, a propósito de la atribución de creencias y de la evaluación de la situación hecha por el agente es preciso tener en cuenta los llamados errores del pensamiento cálido ${ }^{94}$, como los estudiados por Elster y otros autores (la debilidad de la voluntad, el autoengaño, los posibles efectos aberrantes de la interacción entre deseos y creencias, como cuando atribuimos una exagerada probabilidad a aquello que deseamos que ocurra o la disminución de la fuerza del deseo en función de la dificultad, etc.) y la propensión a cometer ciertos errores en la atribución de probabilidades en

\footnotetext{
${ }^{93}$ Ramón Ragués [1999], pág. 521 y ss.

${ }^{94}$ Fernando Broncano [1995], pág. 311.
} 
contextos de incertidumbre o en ciertos tipos de razonamiento lógico. Es decir, el estudio de las perversiones de la racionalidad.

Se trata con ello de acercar la reconstrucción del razonamiento práctico que hizo el agente antes de actuar al que efectivamente realizó, y no al que hubiera realizado el "hombre medio" o el "hombre razonable". Estos dos últimos puntos de vista pueden ser relevantes para juzgar el grado de reproche (señalando que pudo prever o debió prever ciertas consecuencias, por ejemplo), pero en una atribución teórica de intenciones sólo pueden tener una misión heurística y no deben actuar si tenemos razones para pensar que hubo un caso de evaluación equivocada de la situación.

7. Muchas de las acciones que han de examinar los jueces para determinar con qué intención se realizaron tienen lugar en contextos emocionales fuertes, es decir, en situaciones en las que la conducta pudo estar dominada por las emociones. ¿Excluye esto que la acción sea intencional? ¿Pueden las emociones ser causas de la acción de manera que ésta deje de estar dirigida a un fin?

De acuerdo con una sólida tradición que puede remontarse hasta Aristóteles -la teoría cognitivista o evaluativa de las emociones-, las emociones no pertenecen -como a primera vista suele afirmarse- el ámbito de la conducta irracional. Por el contrario, la evaluación de una situación por parte de un agente y la conducta resultante de esa evaluación es parte esencial del concepto de emoción. Por ejemplo, David Casacuberta ofrece la siguiente definición:

"Entendemos por emoción aquello que:

a) Normalmente es producido por una persona que evalúa un evento, conscientemente o inconscientemente, en tanto que resulta relevante para un objetivo o meta que es importante; la emoción se siente como positiva cuando un objetivo es alcanzable y negativa cuando ese objetivo es impedido.

b) El núcleo de una emoción es la facilidad para actuar y para modificar planes; una emoción da prioridad para una o unas pocas líneas de actuación a las que da sensación de urgencia, de forma que pueda interrumpir -o competir con- procesos mentales o acciones alternativas. Diferentes tipos de inmediatez generan diferentes tipos de planificación.

c) Normalmente una emoción se experimenta como un tipo característico de estado mental, a veces acompañada o seguida por cambios corporales, expresiones, acciones" 95 .

${ }^{95}$ David Casacuberta [2000], pág. 128. Esta definición constituye el punto de partida de una serie de matizaciones del autor hasta llegar a una definición más precisa y correcta, pero para nuestros propósitos es suficiente. 
Como muestra esta definición, la conducta causada por una emoción no es conducta ciega y sin dirección. La evaluación de una situación bajo cierto punto de vista nos lleva a actuar de una $\mathrm{u}$ otra manera para conseguir algo querido o evitar algo indeseado. Por ello, dentro de esta concepción las emociones no tienen por qué ser meras causas de las acciones, sino que pueden constituir razones para la acción. Cuando explicamos la deserción de un soldado porque sentía miedo, asumimos que el deseo de huir que acompaña al miedo explica la acción. Como señala William Lyons, muchas emociones están estrechamente vinculadas a un deseo de cierto tipo, y la conducta que suele ser causada por esas emociones puede ajustarse racionalmente a la satisfacción de ese deseo (un sujeto racional correrá ante una situación que le produce terror; correr es una respuesta racional ante esa emoción $)^{96}$.

Las emociones, por tanto, no excluyen el carácter intencional de la acción, sino que, al contrario, pueden verse como determinantes de las intenciones. ¿Por qué Alfredo quiso matar a Herminio? "Por ira”, sería una respuesta satisfactoria. Por tanto, un estudio de las emociones debe formar parte de una teoría de la acción y, también, de la acción intencional ${ }^{97}$.

Por otro lado, las emociones tienen un papel importante en el análisis de lo que he llamado racionalidad mínima y John Watkins llamaba esquemas reales de decisión. Según Damasio, si nuestras decisiones tuvieran que adaptarse a la teoría de la decisión no podríamos tomar decisiones adecuadas debido al elevado número de cursos de acción alternativos que tendríamos que evaluar. Las emociones cumplen el papel de reducir drásticamente las alternativas que serán tenidas en cuenta, ajustando la evaluación a las peculiaridades de cada individuo ${ }^{98}$. Por lo tanto, no desplazan la decisión (de manera que podemos seguir hablando de acción intencional, aunque se realice bajo el influjo de una emoción); aunque sí la determinan en gran medida, por lo que el problema de la responsabilidad por nuestras acciones se desplaza en estos casos a la cuestión de nuestra capacidad de controlar las emociones.

\section{Conclusiones}

1. El problema del conocimiento de las intenciones y otros estados mentales se plantea tanto en el Derecho como en la filosofía. En el Derecho la prueba de la intención (la prueba del dolo) resulta fundamental para estable-

\footnotetext{
${ }^{96}$ William Lyons [1993], págs. 124 y ss.

${ }^{97}$ Sobre la relación entre emociones, racionalidad, intencionalidad y acción puede verse Carlos Moya [2001-a], [2001-b] y Olbeth Hansberg [2001].

${ }_{98}$ A.R. Damasio, El error de Descartes. Tomo la cita de Carlos Moya, Emociones, racionalidad y responsabilidad, pág. 253.
} 
cer la responsabilidad de los sujetos, por lo que constituye una parte central de una Teoría de la Prueba. En la filosofía se plantea cuando se distingue entre acciones y movimientos corporales y se afirma que las primeras, a diferencia de las segundas, requieren una explicación a la luz de razones que las trate como un fenómeno con significado.

2. Entre los juristas se puede apreciar una actitud escéptica acerca de la posibilidad de probar satisfactoriamente las intenciones de los agentes; esta actitud se manifiesta cuando se afirma que la prueba de la intención depende de juicios de valor (como ha sostenido el Tribunal Supremo) o consiste en una imputación, y no en una descripción (como afirma parte de la doctrina penal).

3. Los filósofos que han propuesto esquemas de explicación intencional de la acción se han limitado a lo que podríamos llamar la justificación interna del razonamiento, pero apenas han dado indicaciones útiles para su justificación externa. Ésta requiere la verdad de la premisa que establece la intención, por lo que subsiste la cuestión de cómo verificar esta premisa.

4. Los argumentos para negar que sea posible una descripción genuina de las intenciones de los agentes pueden ser de tres tipos: ontológicos, epistemológicos e ideológicos. Los primeros se basan en las tesis que, al rechazar el dualismo cartesiano, proponen la eliminación de toda referencia a lo mental o al menos la eliminación de algunas de sus propiedades más características, como la consciencia. La principal crítica que puede hacerse a estas tesis es que nos piden aceptar conclusiones muy contraintuitivas, cuando en realidad su fundamentación todavía es una cuestión abierta. Los argumentos epistemológicos señalan que la prueba de la intención es poco fiable o imposible. Hay distintas razones para afirmar esto (menor fiabilidad de la prueba indirecta, inexistencia de leyes que permitan relacionar la conducta externa con su correlato mental, etc.), pero todos los argumentos parecen suponer que puesto que no es posible demostrar sin margen de error qué intención tuvo un agente, debe desistirse de intentarlo. La principal crítica que puede hacerse a este grupo de argumentos es que si se generalizaran coherentemente llevarían también a desistir de casi todo intento de conocer cualquier cosa. El tercer grupo de argumentos aduce que los fines de la pena hacen innecesario o, incluso, inconveniente, tratar de descubrir las intenciones reales de los agentes. La principal crítica a estas posturas consiste en que no dan ninguna relevancia a la reprochabilidad de la conducta a la hora de justificar la imposición de sanciones.

5. Quienes niegan la posibilidad o la conveniencia de descubrir los estados mentales conciben a la prueba de la intención como un razonamiento adscriptivo o atributivo. Sin embargo, no es fácil saber qué quieren decir con esto. "Adscribir" o "atribuir" son expresiones ambiguas, que pueden 
entenderse en un sentido teórico o en un sentido normativo fuerte. Una "atribución en sentido teórico" de una propiedad cualquiera a una entidad es correcta cuando se corresponde con la realidad (por tanto, puede ser verdadera o falsa). Una "atribución en sentido normativo fuerte" es correcta cuando es el resultado de aplicar correctamente ciertas reglas de atribución que no son derrotables por razones teóricas (porque, si lo fueran, las atribuciones normativas serían reducibles a atribuciones teóricas). Creo que, enfrentados a esta distinción, muchos (aunque ciertamente no todos) de los que se consideran adscriptivistas reconducirían su posición a un adscriptivismo débil o teórico, que admitiría que las reglas de atribución no pueden ser arbitrarias, sino que deben tener como horizonte la aproximación a la verdad. Desde esta perspectiva, el adscriptivismo es una postura difícil de rechazar, que se limita a señalar que "descubrir" requiere necesariamente criterios para establecer la verdad (máximas de experiencia, al menos), y que siempre cabe el error. Pero, entendido de esta manera, el adscriptivismo no logra mostrar que la prueba de la intención sea radicalmente distinta de otros tipos de prueba indiciaria (aun sin negar sus peculiaridades).

6. Existe una estrecha conexión entre las nociones de intención y de racionalidad. Esta conexión consiste en que actuar intencionalmente es actuar por lo que el agente considera en el momento de la acción una buena razón, esto es, una razón no derrotada por ninguna otra. Y un agente tiene una buena razón para realizar una acción concreta cuando juzga a ésta como el medio más adecuado para lograr el fin que persigue. Podemos llamar Principio de Racionalidad Mínima a esta conexión entre la actuación intencional y la racionalidad. El PRM no consiste en que los agentes siempre actúan racionalmente, sino en que las acciones intencionales son acciones racionales en este sentido mínimo. Entendido así, tiene carácter conceptual.

7. El razonamiento que concluye en una atribución de intención parte de la descripción de la conducta externa (de una acción en el sentido de "actobásico") y de las creencias del agente y concluye la intención. A partir de él, se puede construir una inferencia práctica que explique por qué el agente realizó determinada acción. El razonamiento atributivo es, por tanto, necesario para la justificación externa de la inferencia práctica ${ }^{99}$.

8. El PRM y la presunción de que la acción que examinamos es intencional son los principales criterios en la atribución de intenciones. Si presumimos que la acción del agente es intencional, encontrar cuál es esta

\footnotetext{
${ }^{99}$ Esto puede significar una crítica a la tesis de von Wright según la cual la verificación de las premisas de una inferencia práctica remite a su conclusión, y la verificación de la conclusión remite a las premisas. Von Wright basa en esta circularidad su afirmación de que la inferencia práctica tiene carácter lógico. G.H. von Wright [1987], pág. 140.
} 
intención consiste en ver hacia dónde apunta instrumentalmente la acción, esto es, en encontrar el fin para el cual esa acción era el medio más adecuado, aquello que hace que el agente tenga una buena razón (desde un punto de vista instrumental) para actuar. Este razonamiento, no obstante, no es lógicamente concluyente. Se trata de una inducción (en el sentido amplio de argumento no deductivo) cuya conclusión (la atribución de intención) sirve a su vez de premisa para la explicación intencional de la acción. Como tal inducción, debe reforzarse examinando cuáles pudieron ser las razones para que el agente persiguiera ese fin (los determinantes de la intención) y descartando que existan otras explicaciones intencionales de la misma acción igualmente plausibles.

9. La atribución de intenciones requiere la atribución de otros estados mentales: las creencias y, en algunos casos, también las emociones. Dado el holismo de lo mental, no es posible la prueba de un hecho psicológico que no requiera la prueba de otro estado mental. Pero si prescindimos de los estados mentales sólo podremos entender las acciones como movimientos corporales y el sistema penal aparecería entonces como un sistema referido a entidades ficticias (las acciones).

10. Los criterios de atribución de intenciones tienen una fundamentación inductiva y "fiabilista" (incluido el carácter conceptual del PRM). Puesto que en el pasado estos criterios y conceptos nos han permitido adecuar nuestra conducta a la de los demás, es razonable seguir confiando en ellos, aunque sepamos que no son infalibles. Esto hace que estos criterios tengan una dimensión epistemológica, orientada a la verdad, y, por tanto, no son reglas de adscripción en sentido fuerte.

\section{Bibliografía}

Achinstein, Peter [1989], La naturaleza de la explicación, Fondo de Cultura Económica, México (trad. de Letizia García Urriza).

Alcacer Guirao, Rafael, Cómo cometer delitos con el silencio. Notas para un análisis del lenguaje de la responsabilidad (en prensa).

Andrés IbáÑEz, Perfecto [1992], Acerca de la motivación de los hechos en la sentencia penal, en Doxa. Cuadernos de Filosofía del Derecho, núm. 12, págs. 257-299. (http://www.cervantesvirtual.com/portal/DOXA/)

BAKER, Gerald y CLARK, Len [1994], La explicación. Una introducción a la filosofía de la ciencia, Fondo de Cultura Económica, México.

Bayón Mohino, Juan Carlos [1991], La normatividad del Derecho: Deber jurídico y razones para la acción, Centro de Estudios Constitucionales, Madrid.

Bechtel, William [1991], Filosofía de la mente. Una panorámica para la ciencia cognitiva, Ed. Tecnos, Madrid (trad. de Luis M1. Valdés Villanueva).

Belloch Julbe, Juan Alberto [1992], La prueba indiciaria, en Cuadernos de Derecho Judicial, XIII. 
Bentham, J, [2001], Tratado de las pruebas judiciales, ed. Comares, Granada (trad. manuel Ossorio Florit).

Broncano, Fernando [1995], El control racional de la conducta, en Fernando Broncano (ed.), La mente humana, Enciclopedia Iberoamericana de Filosofía, ed. Trotta - Consejo Superior de Investigaciones Científicas, Madrid.

Cane, Peter [2000], Mens Rea in Tort Law, en Oxfor Journal of Legal Studies, Vol. 20, núm. 4.

Casacuberta, David [2000], ¿Qué es una emoción? Ed. Crítica, Barcelona.

DAVIDSON, Donald [1995], Acciones, razones y causas, en Ensayos sobre acciones y sucesos, Ed. Crítica, Barcelona (trad. de Olbeth Hansberg, José Antonio Robles y Margarita Valdés).

Dennet, Daniel C. [1985], Mecanicismo y responsabilidad, Cuadernos de Crítica, México (trad. de Myriam Rudoy).

Feinberg, Joel [1968], Action and responsibility, en Alan R. White, The Philosophy of Action, Oxford University Press.

Ferrajoli, Luigi [1997], Derecho y razón. Teoría del garantismo penal, Ed. Trotta, Barcelona (trad. de perfecto Andrés Ibáñez, Alfonso Ruiz Miguel, Juan Carlos Bayón Mohíno, Juan Terradillos Basoco y Rocío Cantarero Bandrés).

Fletcher, George [1997], Conceptos básicos de Derecho penal, ed. Tirant lo Blanch, Valencia (trad. de Francisco Muñoz Conde).

García Amado, Juan Antonio [2000], ¿Dogmática penal sistémica? Sobre la influencia de Luhmann en la teoría penal, en Doxa. Cuadernos de Filosofia del Derecho, núm. 23, Alicante (http://www.cervantesvirtual.com/portal/DOXA/).

García Carpintero, Manuel [1995], El funcionalismo, en Fernando Broncano (ed.), La mente humana, Enciclopedia Iberoamericana de Filosofía, ed. Trotta - Consejo Superior de Investigaciones Científicas, Madrid.

García SuÁrez, Alfonso [1995], Qualia: propiedades fenomenológicas, en Fernando Broncano (ed.), La mente humana, Enciclopedia Iberoamericana de Filosofía, ed. Trotta - Consejo Superior de Investigaciones Científicas, Madrid.

Gascón, Marina [1999], Los hechos en el Derecho. Bases argumentales de la prueba, Marcial Pons, Madrid.

Giner, Salvador [1997], Intenciones humanas, estructuras sociales. Para una lógica situacional, en Manuel Cruz (ed.), Acción humana, Ed. Ariel, Barcelona.

Gómez Rodríguez, Amparo [1992], Sobre actores y tramoyas. La explicación situacional de la acción individual, ed. Anthropos, Barcelona.

- Amparo [1997], Microfundamentos de la explicación social, en Manuel Cruz (ed.), Acción humana, Ed. Ariel, Barcelona.

GonzÁlez Lagier, Daniel [2001], Las paradojas de la acción (Acción humana, Filosofia y Derecho), Publicaciones Universidad de Alicante, Alicante.

- [2003-a], Hechos y argumentos. Racionalidad epistemológica y prueba de los hechos en el proceso penal (I), en Jueces para la democracia, núm. 46.

- [2003-b], Hechos y argumentos. Racionalidad epistemológica y prueba de los hechos en el proceso penal (II), en Jueces para la democracia, núm. 47.

Hampshire, S. y Hart, H. L. A. [1958], Decision, Intencion and Certainty, en Mind, vol. LXVII, núm. 265. 
Hansberg, Olbeth [2001], Las emociones y la explicación de la acción, Isegoría, núm. 25 .

Hart, H. L. A. [1948], The ascription of Responsability and Rights, en Procededings of the Aristotelian Society, Londres.

HiERro, Liborio [1989], Libertad y responsabilidad penal, en Anuario de Derecho Penal y Ciencias penales, Tomo XLII, Fascículo II.

Hornsby, Jennifer [1993], On What's Intentionally Done, en Stephen Shute, John Gardner y Jeremy Horder, Action and Value in Criminal Law, Clarendon Press, Oxford.

JAKoBS, Günther [1997], Sobre el tratamiento de los defectos volitivos y de los defectos cognitivos, en Estudios de Derecho penal, UAM Ediciones - Civitas, Madrid (trad. de Enrique peñaranda ramos, Carlos J. Suárez González y Manuel Cancio Meliá).

JAKsOn, Frank [2001], How Decision Theory Illiminates Assignments of Moral Responsibility, en Ngaire naffine, Rosemary Owens y John Williams, Intention in law and Philosophy, Dartmouth Publishing Company y Ashgate Publishing Company.

Laurenzo Copello, Patricia [1999], Dolo y conocimiento, Tirant lo Blanch, Valencia.

Liz, Manuel [1995], Causalidad y contenido mental, en Fernando Broncano (ed.), La mente humana, Enciclopedia Iberoamericana de Filosofía, ed. Trotta - Consejo Superior de Investigaciones Científicas, Madrid.

Lyons, William [1993], Emoción, Ed. Anthropos, Barcelona (trad. de Inés Jurado).

Mason, Anthony [2001], Intention in the Law Murder, en Ngaire naffine, Rosemary Owens y John Williams, Intention in law and Philosophy, Dartmouth Publishing Company y Ashgate Publishing Company.

Miranda Estrampes, M. [1997], La mínima actividad probatoria en el proceso penal, J.M. Bosch Editor, Barcelona.

Mosterin, Jesús [1987], Racionalidad y acción humana, Alianza Editirial, Madrid.

Moya, Carlos [2001-a], Sentimientos y teoría de la acción, en Isegoría, núm. 25.

- [2001-b], Emociones, racionalidad y responsabilidad, en Filosofía actual de la mente, Contrastes, Suplemento 6.

Mugerza, Javier [1992] Presentación, en Amparo Gómez, Sobre actores y tramoyas. La explicación situacional de la acción individual, ed. Anthropos, Barcelona.

Paredes Castañón, José Manuel [2001], Problemas metodológicos en la prueba del dolo, en Anuario de Filosofía del Derecho, XVIII.

Poggi, Francesca [2004] Proving Intention. Some Remarks, en Jordi Ferrer y Maribel Narváez(eds):"On Knowledge and Adjudication of National and European Law", Dunker \& Humblot, Berlín (en prensa).

RAguÉs y Vallés, Ramón [1999], El dolo y su prueba en el proceso penal, J.M. Bosch Editor, Barcelona.

- [2002], Consideraciones sobre la prueba del dolo, En La Ley, Año XXIII, núm. 5633.

REDONDO, Cristina [1996], La noción de razón para la acción en el análisis jurídico, Centro de Estudios Constitucionales, Madrid. 
Rescher, Nicholas [1993], La racionalidad. Una indagación filosófica sobre la naturaleza y la justificación de la razón, Ed. Tecnos, Madrid (trad. de Susana Nuccetelli).

- [1994], Los límites de la ciencia, ed. Tecnos, Madrid (trad. de Leonardo Rodríguez Duplá).

- [1995], La lucha de los sistemas. Un ensayo sobre los fundamentos e implicaciones de la diversidad filosófica, Universidad Nacional Autónoma de México, México (trad. de Adolfo García de la Sienra; revisión de Héctor Islas Azais).

Rives Seva, Antonio Pablo [1999], La prueba en el Proceso Penal. Doctrina de la Sala Segunda del Tribunal Supremo, Ed. Aranzadi, Pamplona.

Searle, John [1985], Mentes, cerebros y ciencia, ed. Cátedra, Madrid (trad. de Luis Valdés).

- [1992], Intencionalidad, Ed. Tecnos, Madrid (trad. de Enrique Ujaldón Benítez; revisada por Luis Ml. Valdés Villanueva).

- [1996], El redescubrimiento de la mente, Ed. Crítica, Barcelona (trad. de Luis M. Valdés Villanueva).

- [2000-a], El misterio de la conciencia, Ed. Paidós, Barcelona (trad. de Antoni Domènech).

- [2000-b], Razones para actuar. Una teoría del libre albedrio, Ediciones Nobel, Oviedo (trad. de Luis M. Valdés Villanueva).

Stoutland, Frederick [1980], La teoría causal de la acción, en J. Hintikka, A. Macintyre, P. Winch y otros, Ensayos sobre explicación y comprensión, compilación de Juha Manninem y raimo Toumela, Madrid, Alianza Editorial (trad. de Luis Vega).

TARuffo, Michele [2002], La prueba de los hechos, Trotta, Madrid (trad. de Jordi Ferrer Beltrán).

- [2003], Algunas consideraciones sobre la relación entre prueba y verdad, en Daniel González Lagier y Jordi Ferrer Beltrán, Prueba, conocimiento y verdad, Revista Discusiones, Año III, núm. 3.

Toribio Mateas, Josefa [1995], Eliminativismo y el futuro de la psicología popular, en Fernando Broncano (ed.), La mente humana, Enciclopedia Iberoamericana de Filosofía, ed. Trotta - Consejo Superior de Investigaciones Científicas, Madrid.

Von Wright, G. H. [1980-a], El determinismo y el estudio del hombre, en J. Hintikka, A. Macintyre, P. Winch y otros, Ensayos sobre explicación y comprensión, compilación de Juha Manninem y raimo Toumela, Madrid, Alianza Editorial (trad. de Luis Vega).

- [1980-b], Freedom and Determination, Acta Philosophica Fennica, vol. XXXI, núm. 1.

- [1983], Explanation and understanding of Action, en Practical Reason, Philosophical Papers, vol. I, Basil Blackwell.

- [1986], Rationality: means and ends, Epistemologia, IX.

- [1987], Explicación y comprensión, Alianza Editorial, madrid (trad. de Luis Vega).

- [1996], La posición de la psicología entre las ciencias, Lección de doctorado "honoris causa" en la Universidad de Leipzig, 21 de mayo de 1996. 
Von Wright, G.H. [2002], Sobre la libertad humana, Ed. Paidós, Barcelona (trad. de Antonio Canales Serrano).

Watkins, John [1982], Racionalidad imperfecta, en N. Chomsky, S. Toulmin, J. Watkins y otros, La explicación en las ciencias de la conducta, Alianza Editorial, Madrid (trad. de J. Daniel Quesada). 
$\triangle \quad$ DOXA 26 (2003) 


\section{RAZONAMIENTO JUDICIAL Y DERECHOS FUNDAMENTALES Observaciones lógicas y epistemológicas*}

Tecla Mazzarese

Universidad de Brescia

\section{Introducción}

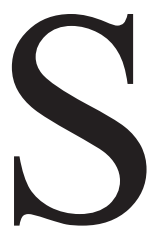

on al menos dos las razones que estimulan una reflexión sobre el razonamiento judicial que tenga en cuenta y que dé cuenta del papel cada vez más invasivo de los derechos fundamentales en las formas y en los modos de la jurisdicción.

Una primera razón es la cada vez mayor atención del legislador (supra)nacional a la definición y articulación de procedimientos judiciales caracterizados por la tutela y la garantía de los derechos fundamentales de las partes de una controversia, pero también de quien debe decidir la controversia, y, no en último lugar, de la colectividad misma en su totalidad (la obligatoriedad de la acción penal, por ejemplo, es, sí, tutela de la imparcialidad y de la independencia de quien juzga, pero también, en relación con la colectividad en su totalidad, una de las formas de realización del principio de igualdad). Atención, ésta del legislador (supra)nacional, para una cada vez más plena realización de un "justo proceso" que encuentra expresión en mecanismos jurídicos que, sin embargo, no siempre ni necesariamente coinciden o concuerdan con criterios, avalorativos y objetivos, de matriz lógica y/o epistemológica. Esta atención, dirigida a una cada vez más plena realización de un "justo proceso", encuentra expresión en una jerarquía de valores en la cual la tutela de los derechos fundamentales puede ser preeminente respecto a la búsqueda de la verdad en la reconstrucción de aquello sobre lo que versa la controversia, del mismo modo que puede ser dirimente en la selección de la interpretación del derecho a aplicar para su resolución.

* Una primera versión de este trabajo fue presentada al Congreso ¿Cómo argumentan los jueces?, desarrollado en San Sebastián el 30 de octubre de 2001 y al primer Seminario Alberto Calsamiglia, desarrollado en Barcelona el 13-14 de febrero de 2003. Agradezco sus comentarios y observaciones a Juan Igartua, Victoria Iturralde Sesma, José Juan Moreso, Maribel Narváez, Giorgio Danesi y Susanna Pozzolo. 
Una segunda razón, además, que estimula una reflexión sobre este tema es la cada vez más difundida praxis jurisprudencial de la justiciabilidad de los derechos fundamentales, aun cuando falte una explícita disciplina legislativa que facilite, si no garantice la tutela judicial. Justiciabilidad que no puede dejar de reflejarse sobre las formas y sobre los modos del razonamiento judicial a causa de las dificultades, epistemológicas y lógicas, debidas a la problematicidad de la noción misma de derechos fundamentales.

Ambas razones concurren, por un lado, a hacer manifiestamente evidente la naturaleza constitutiva y no declarativa de las premisas y conclusiones de las decisiones judiciales $\mathrm{y}$, por otro lado, permiten denunciar el carácter sea derrotable (y/o no monotónico) sea aproximado de las modalidades de razonamiento que llevan a la selección y a la formulación de premisas y conclusiones de las decisiones judiciales. Esta es, en extrema síntesis, la tesis de este trabajo.

Ahora bien, antes de proceder a un examen de algunas de las dificultades epistemológicas (§ 3.2.) y lógicas (§ 3.3.) derivadas de la problematicidad de la noción misma de derechos fundamentales (§ 3.1.) es, sin embargo, oportuno bosquejar, aunque sea sólo sumariamente, los principales rasgos distintivos del llamado Estado constitucional de Derecho (§ 1.), modelo de Derecho, éste, en relación con el cual y en razón del cual los derechos fundamentales han adquirido un papel central en la articulación de las formas y de los modos de la jurisdicción ( $\$ 2$.), condicionando, por ello, las formas y los modos de razonamiento en los que encuentra expresión la aplicación judicial del Derecho.

\section{Derechos fundamentales y Estado constitucional de Derecho}

Es innegable la cada vez mayor centralidad jurídica, además de política, de la tutela de los derechos fundamentales a partir de la segunda mitad del siglo pasado: el fin de la segunda guerra mundial ha marcado, en efecto, a finales de los años cuarenta, las primeras declaraciones solemnes de los mismos a nivel internacional con la Carta de la ONU y con la Declaración Universal de los Derechos del Hombre y, a nivel nacional, con las constituciones de varios países (Italia y Alemania, primero y, después, en los años setenta, España y Portugal). El fin de la guerra fría con la caída del muro de Berlín y la disolución de la Unión Soviética ha vuelto a plantear, quizás con no menor urgencia, la necesidad de una afirmación y tutela tanto nacional (tal como muestra la redacción de los textos constitucionales de muchos países de la Europa oriental y de algunos países asiáticos ${ }^{1}$ ) como supranacional

${ }^{1}$ De particular interés, a este respecto, es el trabajo desarrollado por la llamada Comisión de Venecia, Democracy Through Law. Constituida el 10 de mayo de 1990 por el Consejo de 
(tal como lo revela el debate de hoy sobre un posible constitucionalismo europeo $\mathrm{y}$, aunque en perspectiva más remota, internacional y mundial ${ }^{2}$ ). $\mathrm{Y}$, por último, una reafirmación dramática de la centralidad del problema de la protección de los derechos fundamentales se deriva del atentado terrorista del 11 de septiembre de 2001 contra los Estados Unidos: a pesar, o, más correctamente, precisamente porque, en nombre de la seguridad, amenaza una derogación cada vez más amplia y difusa de tales derechos ${ }^{3}$.

Ahora bien, la positivación (la explícita formulación y enunciación) de los derechos fundamentales en los textos constitucionales y/o en documentos normativos de rango constitucional, conjuntamente con la preadopción de medidas para garantizar su realización y su tutela, ha tenido efectos cada vez más invasivos en los ordenamientos jurídicos contemporáneos en los que ha tenido lugar, condicionando cada vez más radicalmente el concepto mismo de Derecho en su dimensión ontológica, epistemológica y fenome-

Europa, la Comisión de Venecia está compuesta por un representante de cada país de la Unión más un presidente, y sus miembros se encuentran en Venecia para discutir y sugerir posibles soluciones a los problemas de ingeniería institucional que le vienen sometidos por muchos países (sobre todo asiáticos del área de la ex Unión Soviética) que tratan de adecuarse a los estándares de la democracia occidental. Resulta manifiesto el calco de la expresión Democracy through Law de Peace through Law, el título del famoso ensayo de Hans Kelsen aparecido en 1944, en la vigilia de la conclusión del segundo conflicto mundial.

${ }^{2}$ La deseabilidad de un constitucionalismo mundial o internacional, no obstante las manifiestas dificultades con las que no puede dejar de encontrarse la posibilidad de su realización, ha sido afirmada numerosas veces por L. Ferrajoli, por ejemplo, en [1999, pp. 74-76], [2000, pp. 63-69 y 90-96], [2001], [2002 a, pp. 106-107] y [2002 b, pp. 371-377]. Aunque en términos no siempre coincidentes y/o con argumentos no siempre equivalentes, una forma de constitucionalismo mundial y/o internacional y/o una forma de democracia cosmopolita y/o global es auspiciada por J. Habermas, Richard Falk, David Held. Por el contrario, una posición no sólo escéptica, sino drásticamente crítica, ha sido expresada, por ejemplo, por D. Zolo [2002, pp. 57-58], cuando escribe: "autores como Falk y Held están interesados en divulgar algunas consignas sugestivas - global civil society, global constitutionalism, global democracy, cosmopolitan democracy, etc.-, con la tendencia a 'pantografar' a nivel global sus convicciones liberal-democráticas, sin un cuidado preciso ni de especificación normativa e institucional del proyecto de un eventual Estado de Derecho planetario, ni de interacción con las culturas políticas y jurídicas no occidentales, que deberían implicarse en el proyecto cosmopolita. En cuanto a Habermas, no parece albergar ninguna duda sobre el nexo de causalidad evolutiva, por así decirlo, que en su opinión hace descender el "Derecho cosmopolita" del Estado de Derecho y la ciudadanía universal de la ciudadanía democrática. [...] Se trata en todos estos casos de ejemplos muy característicos de una utilización fuertemente etnocéntrica de la domestic analogy, que da por descontada la analogía entre la civil society, que entre los siglos XVII y XVIII ha sostenido el desarrollo del Estado moderno europeo, por una parte, y, por otra, la actual y supuesta global civil society".

${ }^{3}$ Sobre la (amenaza de) una derogación cada vez más amplia y difusa de la tutela de los derechos fundamentales, cfr., por ejemplo, el Informe Anual de Amnesty International de 2002 y la introducción al mismo firmada poor I. Khan; cfr., además, por ejemplo, R. Dworkin [2002 a] y [2002 b] y V. Monetti [2002]. 
nológica; esto es, condicionando y estimulando una redefinición (a) de los criterios de identificación de las normas cuyo conjunto integra y constituye un ordenamiento jurídico (dimensión ontológica), (b) de las formas en que puede darse conocimiento de tales normas (dimensión epistemológica), y (c) de los modos en que puede darse realización y/o aplicación (también) judicial de tales normas (dimensión fenomenológica). Esta redefinición de los criterios de identificación del Derecho, de las formas de su conocimiento y de los modos de su realización y/o aplicación, estimula y legitima la tematización de un modelo jurídico diferente y distinto del propio del Estado (liberal) de Derecho: esto es, el modelo del Estado constitucional de Derecho ${ }^{4}$.

En particular, en primer lugar, los criterios de identificación de las normas de un ordenamiento no se agotan ya (como, sin embargo, era característico de los ordenamientos jurídicos de los Estados liberales de Derecho) en los únicos criterios de carácter formal consistentes en la conformidad de la producción normativa con las metanormas de procedimiento y de competencia, sino que están flanqueados e integrados por criterios de carácter material consistentes en la conformidad de la producción normativa con los valores expresados por los derechos fundamentales explícitamente positivizados $^{5}$. Criterios materiales que son preeminentes y prevalentes respecto a los de carácter formal: aunque aprobada y emanada según los procedimientos previstos por el ordenamiento, una ley, cuyo contenido no sea conforme con los valores expresados por los derechos fundamentales enunciados en

\footnotetext{
${ }^{4}$ Una importancia notable a la oposición terminológico-conceptual entre Estado (liberal) de Derecho o Estado legislativo y Estado constitucional de Derecho es atribuida, por ejemplo, por G. Zagrebelsky [1992], J. Habermas [1996] [1998], L. Ferrajoli [2000], [2001], [2002 a], [2002 b], P. Häberle [2000].

${ }^{5}$ Aunque con distintos énfasis y en una perspectiva teorético-conceptual no coincidente, los criterios materiales de validez no son ignorados por los iuspositivistas. Por el contrario, ya en la primera edición de la Reine Rechtslehre, Hans Kelsen [1934, trad. italiana, pp. 105-106] escribe que la función esencial de la constitución "consiste en regular los órganos y el procedimiento general de la producción jurídica, es decir, de la legislación. La constitución puede, sin embargo, determinar también el contenido de las leyes futuras y no es de ninguna manera infrecuente el caso de que las constituciones positivas hagan esto de forma que ciertos contenidos sean prescritos o excluidos [...] La enunciación de los derechos fundamentales y de libertad que constituye parte integrante típica de las constituciones modernas no es esencialmente otra cosa que una de esas determinaciones negativas. La garantía constitucional de la igualdad ante la ley o de la libertad personal o de conciencia no es otra cosa sino la prohibición de leyes que traten de forma desigual a los súbditos en determinadas relaciones o que invadan una determinada esfera de libertad". Los criterios materiales de validez no son tampoco ignorados por Ross [1958, trad. italiana, pp. 75-76] y [1968, trad. italiana, p. 160] cuando habla de normas de competencia material además de las normas de competencia personal o procedimental.
} 
la constitución, es, en efecto, pasible de anulación, o, según formas diversas de control de legitimidad, de no aplicación judicial. ${ }^{6}$

En segundo lugar, también las formas de conocimiento del material jurídico, la presunta avaloratividad y objetividad en la descripción y sistematización del material normativo, no pueden no reflejar, y estar condicionadas al tiempo, por los valores que, expresados por los derechos fundamentales a nivel constitucional, condicionan tanto la producción como la aplicación de las normas del ordenamiento.

Y, en tercer lugar, los modos de realización y/o aplicación (judicial) del Derecho no se reducen ya (en el caso de que esta reducción haya sido alguna vez efectivamente posible) a un aséptico reconocimiento de la ley o a una concreción mecánica de la misma (tal como se solía afirmar de los ordenamientos jurídicos de los Estados liberales de Derecho) ${ }^{7}$, sino que son ellos mismos inducidos a tener en cuenta los valores expresados por los derechos fundamentales, enunciados a nivel constitucional, tanto en la interpretación, como, si es el caso, en la denuncia de la eventual inconstitucionalidad de la ley.

\section{Derechos fundamentales y aplicación judicial del Derecho}

Son al menos dos, como se ha indicado ya, los perfiles en relación con los cuales los derechos fundamentales revelan su centralidad en la aplicación judicial del Derecho: el primero es el de su papel en la articulación de las formas y los modos de la jurisdicción, esto es, en la (re)definición de las modalidades procedimentales con arreglo a las cuales se da aplicación judicial del Derecho; el segundo perfil es el de su papel, no en la (re)definición de las modalidades procesales, sino en la (y por la) resolución misma de las controversias, esto es, en la identificación y/o en la interpretación del Derecho en base a la cual decidir acerca de las controversias.

Dicho de otra manera, el primero de los dos perfiles es el de los derechos fundamentales sobre la aplicación judicial del Derecho, el segundo es el de los derechos fundamentales en la aplicación judicial del Derecho. ${ }^{8}$ Dos

\footnotetext{
${ }^{6}$ Para un examen de algunas de las principales formas de control de legitimidad en ordenamientos diversos, cfr., por ejemplo, R. Guastini [1998, pp. 328-330] y [2002, pp. 149-151].

${ }^{7}$ Vale, una vez más, cuanto se ha señalado antes en la nota 5 en relación con los criterios materiales de validez: aunque con distinto énfasis y desde una perspectiva teórico-conceptual no coincidente, críticas a una concepción mecanicista y/o logicista de la aplicación (judicial) del Derecho son propias también de los más autorizados exponentes del iuspositivismo del siglo XX, Hans Kelsen, Alf Ross y Herbert Hart.

${ }^{8}$ La distinción entre derechos fundamentales sobre la aplicación judicial del Derecho y derechos fundamentales en la aplicación judicial del Derecho remite a (pero no coincide con) la distinción, propuesta por G. Ubertis [2002, pp.173-174] entre derechos del proceso penal y
} 
perfiles que son, sí, distintos, pero no carentes de relación: la identificación de los derechos fundamentales sobre la aplicación judicial del Derecho se refleja en, y condiciona, al menos en parte, la posibilidad misma de realización y de tutela de los derechos fundamentales en la aplicación judicial del Derecho.

\subsection{Derechos fundamentales sobre la aplicación judicial del Derecho}

A pesar de las críticas con frecuencia fundadas y compartibles sobre los retrasos y/o sobre la inadecuación de las intervenciones legislativas ${ }^{9}$, es sin embargo innegable una manifiesta atención del legislador (supra)nacional a la definición de los modelos procesales caracterizados por la garantía de los derechos fundamentales, esto es, de los modelos procesales que son ellos mismos expresión de una realización plena de los derechos fundamentales y que, al mismo tiempo, posibilitan una efectiva tutela judicial de los derechos fundamentales.

Una confirmación de esta atención es la explícita enunciación de un catálogo más o menos amplio y articulado de derechos fundamentales inherentes a la aplicación judicial del Derecho, tanto a nivel nacional en la constitución de los ordenamientos jurídicos contemporáneos de muchos países (occidentales), como en documentos, solemnes y (aunque no siempre) vinculantes de carácter regional e internacional (así, por ejemplo, en la Declaración Universal de 1948, en la Convención Europea de 1950 y, más recientemente, en la Carta de Niza aprobada en el 2000).

A esta atención manifiesta del legislador (supra)nacional no corresponde, sin embargo, una solución unívoca ni respecto a la selección de los valores a realizar y a tutelar, ni respecto a la selección de los instrumentos más idóneos para su realización.

En particular, no es unívoca la selección de valores: y lo testimonia, más allá de algunas, aun significativas, concordancias, la no equivalencia entre los derechos enumerados en catálogos de ordenamientos distintos, cuando

derechos en el proceso penal. En los términos en los que Ubertis traza la distinción, los derechos del proceso penal son "los derechos reconocidos a las partes (y, sobre todo, al imputado) en el ámbito del proceso, con específica referencia a las actividades procesales, identificando las que resultan indefectibles en cuanto que caracterizantes de la jurisdicción", mientras que los derechos en el proceso penal son "los derechos fundamentales extraprocesales que pueden ser violados por el desarrollo del proceso penal, a fin de determinar si tal cosa está jurídicamente permitida y eventualmente con qué límites y modalidades. Piénsese, por ejemplo, en las hipótesis de arresto o de detención y en las de registro o interceptación telefónica: es evidente que en el primer caso se trata de una limitación del derecho a la libertad personal y en el segundo se trata de una injerencia en el derecho al respeto a la vida privada".

${ }^{9}$ Así, por ejemplo, las enumeradas por M. Taruffo [2002]. 
no en su diversa configuración, en un mismo ordenamiento, respecto de ámbitos procesales distintos.

Y además, no es tampoco unívoca la selección de los instrumentos a adoptar: y lo denuncian las críticas dirigidas con frecuencia a la inadecuación / insuficiencia de las medidas legislativas adoptadas de cuando en cuando.

Atención, por tanto, tan grande y manifiesta como, quizás, amplio y evidente es el disenso que acompaña sea a la selección de los valores de los que se asume que la aplicación judicial del Derecho debe ser garante, sea la especificación de las modalidades juzgadas más idóneas para asegurar su realización.

Atención y disenso que no pueden no reflejarse, una y otro, aun cuando obviamente en términos no siempre equivalentes, sobre las formas y sobre los modos en que se configura el razonamiento judicial en las diversas fases en las que se articula la resolución de una controversia.

\subsection{Derechos fundamentales en la aplicación judicial del Derecho}

No menos central que el papel de carácter procedimental en la articulación de las formas y de los modos de la aplicación judicial es el papel de carácter sustancial que, en muchos ordenamientos jurídicos contemporáneos, los derechos fundamentales tienen en la y para la decisión de las controversias.

No menos relevante es, en efecto, el papel que los derechos fundamentales tienen con frecuencia, en positivo o en negativo, en forma directa o indirecta, en el proceso decisorio que lleva a la solución de una controversia.

En modo positivo cuando se da tutela judicial, en forma directa o indirecta, de los derechos fundamentales. En modo negativo cuando, por el contrario, por razones derivadas del desarrollo de algunas actividades procesales, la ley permite la posibilidad de una derogación de los mismos.

Es relevante su papel en un caso y en el otro.

En negativo, esto es, cuando la ley permite la posibilidad de una derogación de los mismos (así, por ejemplo, la limitación del derecho a la libertad personal en los casos en los que está previsto el arresto o la detención, o la injerencia en el derecho al respeto a la vida privada en los casos en los que están previstos registros o interceptaciones telefónicas ${ }^{10}$ ), su papel es relevante porque testimonia la (potencial) competitividad entre los valores

\footnotetext{
${ }^{10} \mathrm{Y}$ este es el caso al que hace referencia G. Ubertis [2002, p.173] cuando distingue los derechos del proceso penal de los derechos en el proceso penal y caracteriza a estos últimos como "derechos fundamentales extraprocesales que pueden ser violados por el desarrollo del proceso penal".
} 
subyacentes a derechos fundamentales distintos ${ }^{11}$ y ejemplifica la exigencia de una ponderación de los mismos y/o de la definición de una compleja red de excepciones y de vínculos ${ }^{12}$.

En positivo, esto es, cuando se da aplicación judicial de los derechos fundamentales, su papel es relevante no sólo, como es obvio, si y en cuanto que intervienen como (o, al menos, concurren a integrar la) ratio decidendi de una controversia, sino sobre todo porque testimonian el rasgo quizás más significativo de un Estado constitucional de Derecho: la efectiva accionabilidad o justiciabilidad de los derechos fundamentales, no su mera enunciación.

Son distintas las formas, directas e indirectas, en que puede darse aplicación judicial de los derechos fundamentales, también, pero no sólo, en relación con ordenamientos jurídicos diferentes.

Entre las directas, una primera forma de tutela de los derechos fundamentales se da en el caso en que los jueces de primera instancia pueden intervenir sobre el control de constitucionalidad de las leyes, directa o indirectamente: directamente como, por ejemplo, en el caso del ordenamiento de los Estados Unidos caracterizado por un sistema de control difuso de constitucionalidad de las leyes que permite al juez de primera instancia no aplicar una ley que juzgue inconstitucional; indirectamente como, por ejemplo, en el caso del ordenamiento italiano donde el acceso al Tribunal Constitucional por vía incidental permite al juez de primera instancia suspender el juicio, planteando una excepción de constitucionalidad, si y en cuanto que juzgue que la norma a aplicar para la resolución de la controversia es inconstitucional.

Una segunda forma directa de tutela de los derechos fundamentales se da en el caso de eventuales metanormas $y / o$ de posibles prácticas jurisprudenciales que explícitamente sancionen (las primeras), o en todo caso permitan (las segundas), una accionabilidad y/o justiciabilidad directas de los derechos. Por ejemplo: en ausencia de una normativa que discipline sus modalidades de posible realización, absolver, en nombre del derecho de huelga, de la eventual acusación de interrupción de un servicio público a quien, por motivos sindicales y/o reivindicativos, se haya abstenido de trabajar; o, también, en nombre del derecho a la protección del ambiente, condenar actos y hechos que (independientemente de su explícita y circunstanciada prohibición legislativa) constituyan una (grave) amenaza a la protección del ambiente.

\footnotetext{
${ }^{11}$ Sobre la (potencial) competitividad entre valores subyacentes a derechos fundamentales distintos, cfr., infra, $\S 3.2 .3$.

12 Tras las primeras e incisivas formulaciones del problema por parte de R. Dworkin [1968], [1977] y R. Alexy [1985] la literatura sobre el tema es cada vez más amplia. Entre la última, en particular, cfr. B. Celano [2002 b], J.J. Moreso [2002], L. Prieto Sanchís [2002].
} 
Un posible ejemplo de metanorma que establece una directa accionabilidad y justiciabilidad de los derechos fundamentales nos lo ofrece el art. 8 de la Declaración universal de derechos del hombre: "Todo individuo tiene derecho a una efectiva posibilidad de recurso a tribunales nacionales competentes contra actos que violen los derechos fundamentales que le son reconocidos por la constitución o la ley"13.

En ausencia de una metanorma que, como el art. 8 de la Declaración universal, lo sancione explícitamente, la accionabilidad o justiciabilidad de los derechos fundamentales se puede hacer realidad por medio de la consolidación de prácticas jurisprudenciales. Prácticas que, en el léxico de Guastini, testimonian el grado de "constitucionalización" de un ordenamiento ${ }^{14}$.

Una tercera forma directa de tutela de los derechos fundamentales se puede quizás afirmar que se realiza también en todo ordenamiento en el que esté vigente el principio de obligatoriedad de la acción penal, esto es, en todo ordenamiento que considere la lesión de los derechos fundamentales que se determina con la comisión de un delito, tan grave como para ser condición suficiente para que se investigue sobre tal lesión incluso en ausencia de una denuncia por parte de quien haya sido la víctima de la misma.

Entre las formas indirectas de tutela y realización se puede incluir, quizás, la relativa a la aplicación de las leyes que, de uno o varios derechos fundamentales enunciados a nivel constitucional, especifican, al menos en parte, los términos de realización y tutela y/o circunscriben su alcance respecto a los valores de los que pueden ser expresión. Esta fórmula de tutela es indirecta, si y en cuanto la definición legislativa de los términos en los que configurar la realización y la tutela de uno o varios derechos fundamentales constituye, de hecho, un filtro respecto a la variedad de sus posibles lecturas o a la pluralidad de modos de entender los valores de los que son expresión; esto es, un filtro respecto a la pluralidad de formas posibles de justiciabilidad de los mismos.

Entre las formas indirectas de tutela y realización se incluye, sin embargo, a título pleno, la práctica jurisprudencial de reclamar derechos fundamentales (sancionados a nivel constitucional) como instrumento de interpretación (como clave de lectura privilegiada) de las leyes a aplicar, esto es, la práctica de la llamada interpretación adecuadora de la ley ${ }^{15}$.

\footnotetext{
${ }^{13}$ La tutela judicial de los derechos fundamentales es explícitamente afirmada también por el art. 7 de la Declaración Universal de 1948, por el art. 13 de la Convención Europea de 1950, y por el art. 24 de la Constitución italiana.

${ }^{14}$ Cfr. R. Guastini [2002].

${ }^{15}$ La expresión es de R. Guastini [2002, p. 155] quien aclara: "La interpretación adecuadora es [...] la que adecua, armoniza, la ley a la constitución (previamente interpretada, se
} 
Papel éste de los derechos fundamentales en el proceso decisorio de la aplicación judicial del Derecho que, en negativo o en positivo, en forma directa o en forma indirecta, si bien no siempre en términos coincidentes, se refleja sobre el razonamiento judicial enfatizando su carácter aproximado y derrotable a un tiempo.

\section{Derechos fundamentales y razonamiento judicial}

Es difícil negar, como muestran las observaciones que anteceden, el papel cada vez más invasivo y preponderante de los derechos fundamentales, sea en el aspecto procedimental, en la articulación de las formas y de los modos de la jurisdicción, sea en el aspecto sustancial, en la resolución misma de la controversia. Es tan innegable, en el ordenamiento jurídico de un Estado constitucional de Derecho, la invasividad de su papel (también) en materia de aplicación judicial del Derecho, como lo es la problematicidad de su noción (§ 3.1.). Problematicidad que encuentra confirmación tanto a nivel epistemológico respecto a la definición de los cánones de cognoscibilidad de lo que se asume que tenga (pueda y/o deba tener) valor de derechos fundamentales (§ 3.2.), como a nivel lógico respecto a la caracterización de los instrumentos lógicos idóneos para dar cuenta del carácter derrotable y aproximado de los argumentos que intervienen en el razonamiento judicial cuando éste tiene como objeto la realización y/o la tutela de los derechos fundamentales (§3.3.).

\subsection{Derechos fundamentales: una noción problemática}

La noción de 'derechos fundamentales' es controvertida, y no puede no serlo, porque tiene, y no puede no tener, una intrínseca connotación axiológica; porque es, y no puede no ser, dependiente y subsidiaria de la noción de valores ${ }^{16}$.

Los derechos fundamentales, en efecto, son la afirmación de valores a realizar, tutelar o promover (como, por ejemplo, la igualdad, la equidad, la dignidad humana, la libertad individual, la paz) y/o la afirmación de medios necesarios para la realización, la tutela o la promoción de valores (como, por

entiende), escogiendo - frente a una doble posibilidad interpretativa- el significado (o sea, la norma) que evita toda contradicción entre ley y constitución. El efecto de tal interpretación es obviamente el de conservar la validez de una ley que, de otra forma, debería ser declarada inconstitucional". La interpretación adecuadora es, en el análisis de Guastini, una de las condiciones del proceso de constitucionalización de un ordenamiento jurídico.

${ }^{16}$ En una perspectiva no del todo coincidente con la adoptada en el texto, de la problematicidad de la noción de derechos fundamentales y de los principales órdenes de dificultades con los que se enfrenta todo intento de delinear una teoría de los derechos fundamentales, me he ocupado en [2002, en particular pp. 22-32] y [2003]. 
ejemplo, el derecho a la educación escolar como medio de promoción de la dignidad humana o el derecho a la libertad religiosa como medio de tutela de la libertad individual). En ambos casos, los derechos fundamentales son entidades fundadas en valores, y precisamente porque son la afirmación de valores y/o de medios necesarios para su realización y tutela adquieren ellos mismos una intrínseca connotación axiológica ${ }^{17}$. Íntima conexión con los valores y, por ello, intrínseca connotación axiológica, que, es oportuno subrayarlo, es independiente tanto de las diversas concepciones sobre su eventual fundamento último, como la opción por una posible denominación distinta de los mismos (como, por ejemplo, derechos humanos, derechos naturales, derechos subjetivos o derechos constitucionales).

Ahora bien, si y en cuanto entidades de naturaleza instrínsecamente axiológica, su identificación es todo menos obvia e inmediata porque, banalmente, es todo menos obvia e inmediata la identificación de los valores de los que deben ser expresión o instrumento de realización. Dicho de otra forma, la falta de consenso sobre el (re)conocimiento de cuáles sean (puedan, deban ser) los valores a afirmar no puede dejar de reflejarse sobre el (re)conocimiento de cuáles sean (puedan, deban ser) los derechos fundamentales a tutelar.

Y también, si y en cuanto entidades de naturaleza axiológica no disímiles de los valores de los que son expresión o instrumento de realización, se plantean dos preguntas de importancia central bajo el prisma jurídico y bajo el más específicamente judicial: la primera pregunta es si la positivación (la enunciación explícita) en un ordenamiento jurídico (nacional) es condición necesaria para que, en ese ordenamiento, se pueda tener tutela judicial de un derecho fundamental; la segunda pregunta es si la positivación (la enunciación explícita) en un ordenamiento jurídico (nacional) es condición suficiente para que, en ese ordenamiento, se deba tener tutela judicial de un derecho fundamental.

Si y en cuanto entidades de naturaleza axiológica no disímiles de los valores de los que son expresión o instrumento de realización, los derechos fundamentales justifican, por tanto, dudas y preguntas que no pueden dejar de traducirse en dificultades epistemológicas sobre las formas y modos de su eventual cognoscibilidad, y en dificultades lógicas sobre las formas y modos en que se configuran el razonamiento y la argumentación jurídica, y más específicamente judicial, cuando tienen como objeto (también) los derechos fundamentales.

\footnotetext{
${ }^{17}$ Retomo aquí la caracterización de la noción de derechos fundamentales que he propuesto anteriormente en [1993, p. 204].
} 


\subsection{Dificultades epistemológicas}

Bajo el prisma epistemológico, los principales órdenes de dificultades a los que da origen y con los que se encuentra la noción de derechos fundamentales son dos, estrechamente conectados entre sí.

El primer orden de dificultades afecta a la (re)definición de los criterios de identificación del Derecho (i.e. de las normas válidas cuyo conjunto integra y constituye un ordenamiento jurídico) y a la definición de los cánones de cognoscibilidad de los mismos derechos fundamentales que constituyen la dimensión sustancial (junto y más allá de la dimensión formal de conformidad con las metanormas de procedimiento y/o de competencia) de los criterios de identificación del Derecho válido, esto es, la conformidad (o al menos la no disconformidad) con los valores de los que ellos mismos son expresión.

El segundo orden de dificultades afecta a la (re)afirmación, en términos quizás más radicales de lo que lo han sido en su versión antiformalista, de la tesis de la no univocidad de la interpretación jurídica. No univocidad tanto de las modalidades de ejecución como de los resultados de la interpretación jurídica, tanto en el caso de que su objeto esté constituido por las disposiciones (constitucionales) que son formulación de derechos fundamentales, como en el caso de que su objeto esté constituido por la (re)lectura de las disposiciones legislativas sobre la base de los valores de los que los derechos fundamentales son expresión.

Los dos órdenes de dificultades están estrechamente conectados, si bien no son necesariamente coincidentes: las dificultades de fijar cánones de cognoscibilidad de los derechos fundamentales (y, a partir de ahí, de las normas que integran o constituyen un ordenamiento si y en cuanto que su validez dependa, al menos, también de su no disconformidad con los valores de los que los derechos fundamentales son expresión) no pueden, en efecto, no reflejarse también sobre las dificultades relativas a la interpretación (de las disposiciones fundamentales que son formulación) de los derechos fundamentales, así como sobre las dificultades de una interpretación de las disposiciones legislativas que se reclame a los valores de los que los derechos fundamentales son expresión. Estos dos órdenes de problemas no pueden dejar de estar estrechamente conectados porque identificación e interpretación del Derecho válido son dos momentos, complementarios y simétricos, del conocimiento del Derecho.

Ahora bien, estos dos órdenes de problemas (tanto el relativo a la identificación como el relativo a la interpretación del Derecho válido en razón del papel que los derechos fundamentales tienen para el uno y para el otro de los dos momentos de conocimiento del Derecho), son consecuencia de una triple fuente de indeterminación del conjunto de los derechos fundamenta- 
les, del conjunto de lo que, según los casos, se asume que tiene (puede y/o debe tener) valor de derechos fundamentales ${ }^{18}$. Triple fuente de indeterminación que, precisamente en razón de la íntima connotación axiológica de los derechos fundamentales ( $\$ 3.1$ ), parece ser ineludible independientemente del cuidado que se ponga en la redacción y articulación de un catálogo de los mismos.

La primera razón de la indeterminación del conjunto de los derechos fundamentales de los que hay que garantizar tutela judicial es debida al disenso sobre cuáles son (pueden y/o deben ser) los derechos fundamentales a incluir en tal conjunto ( $\$ 3.2 .1$ ); la segunda y la tercera razón de indeterminación, una vez identificados y/o formulados los derechos fundamentales del conjunto, son debidas, por el contrario, a la pluralidad de lecturas de que (la formulación de) cada derecho fundamental es susceptible (sobre todo, pero no exclusivamente) en razón de la variedad de concepciones del valor (y/o de los valores) del que él mismo es expresión (§3.2.2) y a la (potencial) competencia (sincrónica y diacrónica) entre derechos fundamentales distintos de un mismo conjunto (\$3.2.3.).

Dicho de otra forma, la primera razón de la indeterminación afecta a los criterios de identificación de los derechos fundamentales a incluir en la redacción de su catálogo (y, por tanto, también a la respuesta a la interrogante de si su catálogo debe considerarse cerrado o abierto); la segunda y la tercera razón afectan, por el contrario, a los criterios de interpretación (de las formulaciones) de los derechos fundamentales incluidos en un catálogo dado tanto en razón de la pluralidad de concepciones de los valores subyacentes a los mismos, como en razón de su (potencial) competencia (sincrónica y diacrónica).

\subsubsection{Indeterminación y criterios de identificación de los derechos fundamentales}

La primera razón de la indeterminación de los derechos fundamentales cuya tutela judicial debe garantizarse se debe al disenso sobre cuáles son (pueden y/o deben ser) los derechos fundamentales a incluir en tal conjunto.

Este disenso, al contrario de lo que quizá se podría pensar, no es tanto relativo a la clásica pregunta por el fundamento último, sino más bien (a) a la diversidad de valores que, de acuerdo con distintas concepciones (sean és-

\footnotetext{
${ }^{18}$ Sobre esta triple fuente de indeterminación [fuzziness] del conjunto de los derechos fundamentales, cfr. también Tecla Mazzarese [1993], [2002, pp. 30-31], M. Koskenniemi [1999], B. Celano [2002]. Aunque en términos no del todo coincidentes, de esta triple fuente de indeterminación ya hay mención en N. Bobbio [1968 (1 $\left.1^{\mathrm{a}}\right), 1992\left(2^{\mathrm{a}}\right)$, p. 38].
} 
tas morales, religiosas, ideológicas o políticas), se juzga que son los valores a realizar y a defender mediante la enunciación de derechos fundamentales y mediante la reivindicación de su protección, y (b) a la diversidad de derechos fundamentales que, de acuerdo con distintas concepciones (sean éstas morales, religiosas, ideológicas o políticas) se juzga que son los derechos fundamentales que constituyen los medios necesarios para promover y garantizar los valores que se ha decidido realizar y defender (a la diversidad, esto es, de lo que puede ser considerado como un medio necesario para la realización de un valor dado).

El disenso sobre la identificación de los derechos fundamentales no se agota, pues, en la búsqueda de un posible fundamento último de los mismos. Es difícil no compartir, en efecto, la afirmación de Bobbio con arreglo a la cual una búsqueda semejante no es otra cosa que una ilusión. Escribe Bobbio: "Esta ilusión fue común durante siglos a los iusnaturalistas, quienes creyeron haber puesto ciertos derechos (pero no eran siempre los mismos) al resguardo de cualquier posible impugnación derivándolos directamente de la naturaleza del hombre"19. Y también: "Esta ilusión hoy ya no es posible; toda búsqueda del fundamento absoluto es, a su vez, carente de fundamento" ${ }^{20}$. De aquí la advertencia de Bobbio, según la cual: "El problema de fondo referente a los derechos del hombre es hoy no tanto el de justificarlos, como el de protegerlos. No es un problema filosófico, sino político"21.

Ahora bien, aunque consecuente bajo el perfil pragmático y deseable bajo el perfil jurídico, político y ético, la advertencia de Bobbio corre el riesgo, sin embargo, de ser confundente. Corre el riesgo de ser confundente porque deja irresuelta la pregunta de fondo de cuáles son los derechos fundamentales a proteger y a volver efectivos; esto es, porque no dice cuál es (puede o debe ser) el criterio de identificación y definición del conjunto de los derechos fundamentales en relación con los cuales, sin embargo, reivindica la urgencia de que sean "garantizados". Es decir, es una advertencia que corre el riesgo de ser confundente precisamente porque, implícitamente, presupone un criterio que permite reconocer qué es lo que tiene (puede o debe tener) valor de derecho fundamental. Pero, en contraste con esa asunción implícita, la falta (el disenso sobre la identificación) de tal criterio es precisamente la

\footnotetext{
${ }^{19}$ N. Bobbio [1965 (1 $\left.1^{\mathrm{a}}\right), 1992\left(2^{\mathrm{a}}\right)$, pp. 6-7].

${ }^{20} \mathrm{~N}$ Bobbio [1965 (1 $), 1992\left(2^{\mathrm{a}}\right)$, p. 7].

${ }^{21}$ N. Bobbio [1965 (1 $\left.{ }^{\mathrm{a}}\right), 1992\left(2^{\mathrm{a}}\right)$, p. 16, cursiva del autor]. Advertencia, ésta, repetida por Bobbio pocos años después [1968 $\left(1^{\mathrm{a}}\right), 1992\left(2^{\mathrm{a}}\right)$, pp. 17-18], cuando afirma que "El problema al que nos enfrentamos [...] no es filosófico sino jurídico, y en un sentido más amplio político. No se trata tanto de saber cuáles y cuántos son estos derechos, cuál es su naturaleza y su fundamento [...], sino cuál es la forma más segura de garantizarlos, para impedir que, a pesar de las declaraciones solemnes, sean violados continuamente".
} 
principal fuente de dificultades, de carácter teórico y filosófico, que vuelve problemática la noción de derechos fundamentales bajo el perfil jurídico y, en particular, bajo el judicial. Y de esta dificultad el propio Bobbio muestra ser plenamente consciente, cuando afirma que "más allá de las dificultades jurídico-políticas, la tutela de los derechos del hombre hace frente a dificultades inherentes al contenido mismo de estos derechos"22.

El núcleo de las dificultades que examinamos encuentra numerosas confirmaciones tanto en relación al Derecho internacional, como en relación al Derecho interno de cada uno de los Estados.

En particular, con referencia al Derecho internacional, son conocidas las críticas dirigidas al catálogo de derechos fundamentales enumerados en las cartas y/o en los pactos que se han sucedido a partir de la Declaración Universal de 194823; críticas que, aunque formuladas y argumentadas de formas diversas, denuncian, todas ellas, la connotación ideológico-cultural de matriz occidental y problematizan, cuando no niegan directamente, la pretendida universalidad (de parte) de los derechos fundamentales que han encontrado una afirmación explícita en estos documentos.

Y además, con referencia al Derecho interno de un Estado, la duda es si los derechos fundamentales de los que garantizar la tutela judicial son todos y sólo aquellos que han tenido ya un reconocimiento explícito, una enunciación explícita, en el ordenamiento jurídico estatal. En otras palabras, la duda puede ser reformulada apelando a los dos interrogantes ya identificados cuando se ha subrayado el intrínseco valor axiológico de los derechos fundamentales (§ 3.1.), es decir: (a) la pregunta sobre si la positivización (la enunciación explícita) en un ordenamiento jurídico (nacional) es condición necesaria para que, en ese ordenamiento, se pueda tener tutela judicial de un derecho fundamental; y (b) la pregunta sobre si la positivización (la enunciación explícita) en un ordenamiento jurídico (nacional) es condición

${ }^{22}$ N. Bobbio [1968 $\left(1^{\mathrm{a}}\right), 1992\left(2^{\mathrm{a}}\right)$, p.38]. Una confirmación ulterior de la plena consciencia de la dificultad que examinamos es la respuesta sugerida por Bobbio para superarla (p.18): "cuando digo que el problema cada vez más urgente frente al que nos encontramos no es el problema del fundamento sino el de las garantías, quiero decir que consideramos el problema del fundamento no como inexistente, sino, en cierto sentido, como resuelto [...]. Se puede decir, en efecto, que hoy el problema del fundamento de los derechos del hombre ha tenido su solución en la Declaración Universal de los derechos del hombre, aprobada por la Asamblea General de las Naciones Unidas el 10 de diciembre de 1948”. Si esta respuesta resuelve o más bien replantea la dificultad que examinamos es dudoso. Así lo muestran, por ejemplo, las observaciones de L. Baccelli [1999, pp. 96-100] y [2002, pp. 135-136].

${ }^{23}$ Sobre el complejo entrecruzamiento de disensos políticos y tensiones ideológicas en la base de la redacción de la Declaración Universal de 1948, cfr., por todos, A. Cassese [1994, pp. 21-49]. 
suficiente para que, en ese ordenamiento, se deba tener tutela judicial de un derecho fundamental.

Una respuesta afirmativa a estas dos preguntas permitiría ciertamente evitar embarazosos y discutibles compromisos de matriz iusnaturalista. Pero, aunque fuese deseable, una respuesta afirmativa a estas dos preguntas se enfrenta con la opinión ampliamente compartida, de acuerdo con la cual, por decirlo con Bulygin: "los derechos humanos no pueden reducirse a la regulación normativa de un orden jurídico positivo, pues ellos ofrecen justamente el marco dentro del cual es posible la críticas de las leyes o instituciones del Derecho positivo"24.

Esta opinión, expresada por un iuspositivista sincero como Bulygin, independientemente de cualquier propensión iusnaturalista, parece encontrar confirmación en algunas formulaciones tanto del Derecho público internacional como de algunos textos constitucionales nacionales. Así, por ejemplo, la novena enmienda de la Constitución de los Estados Unidos afirma que: "The enumeration in the Constitution, of certain rights, shall not be construed to deny or disparage others retained by the people", y según el art. 2 de la Constitución italiana: "La República reconoce y garantiza los derechos inviolables del hombre, tanto como individuo como en las formaciones sociales donde se desarrolla su personalidad, y exige el cumplimiento de los deberes inderogables de solidaridad política, económica y social"25.

\subsubsection{Indeterminación y criterios de interpretación: la formulación} de los derechos fundamentales

El conjunto de derechos fundamentales de los que asegurar la tutela judicial no se encuentra indeterminado sólo en razón de las diversas orientaciones posibles de los jueces respecto a los (presuntos) derechos fundamentales que no han encontrado positivización explícita en el Derecho interno. Tal conjunto continuaría siendo indeterminado aun en el caso de que se decidiese circunscribirlo a los derechos fundamentales explícitamente establecidos en un ordenamiento dado.

Una primera razón de esta afirmación es, banalmente, que la formulación lingüística de las disposiciones jurídicas que expresan derechos fundamentales es vaga, y no sólo general. Por citar un caso ya propuesto por Dworkin, piénsese, por ejemplo, en la llamada Equal Protection Clause

\footnotetext{
${ }^{24}$ E. Bulygin [1987 (1 $)$, $1991\left(2^{\mathrm{a}}\right)$, p. 619].

${ }^{25}$ Con referencia a la Constitución italiana y a su artículo 2, el problema que examinamos es afrontado, por ejemplo, por A. Barbera [1975, pp. 80-101] y A. Pace [2001]. Más en general, cfr., además, T. Mazzarese [1993], [2002, p. 23], R. Guastini [1998, pp. 343-344], G. Rolla [2001, pp. 21-26].
} 
formulada en la décimocuarta enmienda de la Constitución de los Estados Unidos. "Nor shall any State [...] deny to any person within its jurisdiction the equal protection of law". Como subraya el propio Dworkin: "The Clause makes the concept of equality a test of legislation, but it does not stipulate any particular conception of that concept"26.

Una razón ulterior de la afirmación que examinamos viene dada por el hecho de que un rasgo distintivo de la formulación lingüística de las disposiciones jurídicas que expresan derechos fundamentales es el uso de términos valorativos. Un ejemplo paradigmático es identificado por Twining y Miers ${ }^{27}$ en la formulación del artículo 3 de la Convención Europea sobre Derechos Humanos de 1950: "No one shall be subjected to torture or to inhuman or degrading treatment and punishment". La naturaleza emotiva (o, dicho de otra forma, valorativa y vaga) de los términos "tortura", "inhumano" y "degradante" que aparecen en la formulación de este artículo es puesta incisivamente en evidencia por Twining y Miers por medio de una serie de preguntas que permiten ver con claridad la pluralidad de lecturas y/o dudas interpretativas de las que cada uno de estos términos puede ser susceptible.

Las consecuencias de la indeterminación característica de las formulaciones lingüísticas de las disposiciones que expresan derechos fundamentales son, en sede interpretativa, tan obvias como manifiestas. Indeterminación que no puede dejar de reflejarse y encontrar expresión en una discrecionalidad claramente más acentuada que la que acompaña a la interpretación de cualquier formulación lingüística de una ley. Incluso dejando de lado la duda de si la diferencia es sólo cuantitativa y no más bien cualitativa, es difícil no compartir, extendiéndola a la mayor parte de los derechos fundamentales, la consideración que hace Cappelletti en relación con los derechos de welfare (esto es, con los derechos sociales, económicos y culturales): "The creative character of judicial interpretation and enforcement of [...] welfare laws and rights can hardly be hidden. To be sure, the difference vis$\grave{a}$-vis the more traditional role of the judges is one of degree, not of essence. Interpretation is always creative, and at least a minimum of discretion is unavoidable in any kind of judicial interpretation. Yet, as a rule, creativity is both more apparent and more accentuated in these newer areas which have opened up to the judicial function. For the more vague a statute and the less defined a right, the more space is obviously left for the discretion in judicial decision-making" 28 .

\footnotetext{
${ }^{26}$ R. Dworkin [1977, p. 226].

${ }^{27}$ W. Twining y D. Miers [1976 (1 $\left.1^{\mathrm{a}}\right), 1982\left(2^{\mathrm{a}}\right)$, pp. 61-62].

${ }^{28}$ M. Cappelletti [1989, p. 16].
} 
Esta segunda fuente de indeterminación del conjunto de los derechos fundamentales pone de relieve una dificultad obvia para su tutela judicial. Sorprendentemente, sin embargo, esta fuente de indeterminación no siempre es (ha sido) considerada un rasgo problemático para la justiciabilidad de los derechos fundamentales. En particular no es (ha sido) considerada un rasgo problemático, por ejemplo, en la literatura angloamericana sobre la interpretación constitucional. Literatura, ésta, en la cual no resulta en absoluto aislada o minoritaria la posición de quien identifica en el carácter vago y valorativo de la formulación lingüística de las disposiciones jurídicas que expresan derechos fundamentales no un defecto, sino un mérito; esto es, la posición de quien, precisamente en el carácter vago y valorativo de sus formulaciones identifica aquello que permite a los jueces hacer efectivos los derechos fundamentales en la evolución progresiva de los mismos que acompaña a la emergencia de nuevas necesidades de toda sociedad en vía de desarrollo. Es significativa la confirmación de esta posición que ofrece Hufstedler cuando escribe: "I intend no irony in describing the words from the Bill of Rights as 'glorious ambiguities'. The very elusiveness of their content has made it possible to shape and reshape constitutional doctrine to meet the needs of an evolving, pluralistic, free society. Precision has an honored place in writing a city ordinance, but it is a death warrant for a living constitution" 29 .

Y también en la literatura neoconstitucionalista, aun cuando en términos no coincidentes y con argumentos no siempre equivalentes, la vaguedad y el carácter valorativo de las formulaciones lingüísticas de los derechos fundamentales positivizados son con frecuencia considerados como un rasgo no negativo, sino (potencialmente) positivo. Es así, en particular, en los análisis de quien a un Derecho cierto contrapone un Derecho dúctil ${ }^{30}$, de quien a la certeza del Derecho contrapone como valor distinto y preeminente el valor de la equidad, de la justicia del caso particular.

\subsubsection{Indeterminación y criterios de interpretación: la (potencial) competitividad entre derechos fundamentales}

Y además, una fuente ulterior de indeterminación del conjunto de los derechos fundamentales de los que garantizar la tutela judicial es la (potencial)

${ }^{29}$ M. Hufstedler [1979, pp. 4-5]. La afirmación recogida en el texto es optimista y al mismo tiempo unilateral: es difícil ignorar, en efecto, que la indeterminación de la formulación lingüística de los derechos fundamentales puede ser (y de hecho ha sido) un instrumento que permite a los jueces perseguir fines diversos y en conflicto entre sí; esto es, que es un medio que los jueces pueden usar tanto para tener en cuenta la emergencia de nuevas necesidades en "an evolving, pluralistic, free society", como para ignorarlas y negarlas.

${ }^{30}$ Así, en particular, G. Zagrebelsky [1992]. 
competitividad de los derechos fundamentales, tanto en el caso de que su catálogo se encuentre circunscrito al conjunto de los derechos explícitamente reconocidos en el Derecho interno, como en el caso en que se convenga que también pueden tomarse en cuenta derechos proclamados en ámbito supranacional ${ }^{31} \mathrm{y} / \mathrm{o}$ derechos no explícitamente enunciados en disposiciones de Derecho positivo ${ }^{32}$.

Son dos los principales tipos de conflicto que pueden darse entre derechos fundamentales, independientemente del hecho de que los mismos estén o no expresamente enunciados en un determinado ordenamiento jurídico ${ }^{33}$ : (a) conflictos que derivan de concepciones distintas y divergentes del valor del que un mismo derecho fundamental es expresión o instrumento de realización, y (b) conflictos que derivan de la imposibilidad de tutelar y/o de realizar un derecho fundamental sin violar otro, o, al menos, sin circunscribir el posible alcance de este último.

En particular, como se ha subrayado ya (§ 3.1.), todo derecho fundamental puede ser considerado como una entidad de naturaleza axiológica. Dicho de otra forma, todo derecho fundamental expresa y/o es instrumento de la

${ }^{31}$ Son dos los ejemplos que G. Rolla [2001, p. 23] señala de "cláusulas que abren el ordenamiento nacional a las codificaciones internacionales en materia de derechos fundamentales de la persona": el art. 10 de la Constitución española ("Las normas relativas a los derechos fundamentales y a las libertades que la Constitución reconoce se interpretarán de conformidad con la Declaración Universal de derechos humanos y los tratados y acuerdos internacionales sobre las mismas materias ratificados por España”), y el art. 16 de la Constitución portuguesa ("Las disposiciones constitucionales y legales relativas a los derechos fundamentales deben ser interpretadas e integradas en armonía con la Declaración universal de derechos humanos").

${ }^{32}$ Dos ejemplos posibles, ya recordados en el texto (§3.2.1.): la novena enmienda de la Constitución de los Estados Unidos y el art. 2 de la Constitución italiana. También, siguiendo a G. Rolla [2001, pp. 24-25], que los caracteriza como "cláusulas generales de apertura que se remiten al valor fundamental de la persona y a su libre desarrollo", pueden identificarse ulteriores ejemplos en el art. 2 de la Ley Fundamental alemana y en el art. 5 de la Constitución griega.

${ }^{33}$ Independientemente de cualquier diferencia a la hora de caracterizarlos y/o de distinguir entre ellos diversos tipos, los conflictos entre derechos fundamentales han sido indicados con frecuencia como una de las principales dificultades que obstaculizan una realización completa y una tutela plena de los derechos fundamentales. Así, por ejemplo, N. Bobbio [1965], [1968], T. Mazzarese [1993], G. Corso [1996], R. Guastini [1998, pp. 228-231], M. Koskenniemi [1999, pp. 107-111], L. Prieto Sanchís [2002]. En particular, según N. Bobbio [1965], el conflicto entre derechos fundamentales identifica una de las razones que impiden indicar un fundamento último de los mismos. En contraste con esta opinión recurrente, L. Ferrajoli [2000, pp. 51-52 y 77-79] critica radicalmente la posibilidad de conflictos entre derechos fundamentales. Según Ferrajoli, en efecto: "No tiene sentido hablar de 'conflictos' o peor aún de tendenciales o virtuales incompatibilidades entre libertad negativa de un lado y derechos de autonomía civil y política del otro. Se debe hablar más bien, una vez esclarecida la diversa estructura y naturaleza de los derechos primarios y secundarios, de una oposición menos problemática pero más seria e importante: de los límites impuestos a la genérica libertad negativa por el ejercicio directo o indirecto de los derechos de autonomía, dentro de los límites impuestos a estos por los derechos de libertad" (p. 51). 
realización de valores. Así, sólo para dar algún ejemplo, éste es el caso de la igualdad, de la libertad individual, del respeto a la dignidad humana. Valores, éstos, cada uno de los cuales, como es bien sabido, ha sido entendido en una diversidad de formas distintas; valores, éstos, que de forma paradigmática ejemplifican, todos ellos, lo que Gallie ha propuesto llamar "contested concepts" $" 34$. Se sigue de ello, como es obvio, que todo derecho fundamental puede ser leído de tantas formas cuantas son las diferentes concepciones de los valores de los que él mismo es expresión y/o instrumento de realización. $\mathrm{Y}$, como es obvio, lecturas distintas de un mismo derecho son, en medida más o menos clara según los casos, conflictivas entre sí.

Y además, si y en cuanto son entidades de naturaleza axiológica no diferentes de los valores de los que son expresión o instrumento de realización, etiquetar como fundamental (o, análogamente, como humano o natural) un determinado derecho entraña, de ordinario, la asunción de que el mismo vale universalmente, sin ninguna restricción. Es decir, que la protección y la realización de un derecho fundamental debería encontrarse garantizada siempre y a todos. Esta lectura intuitiva de la noción que estamos examinando vale, sin embargo, sólo para algunos derechos fundamentales clásicos y, como subraya Bobbio: "En la mayor parte de las situaciones en las que está en cuestión un derecho del hombre, sucede [...] que dos derechos igualmente fundamentales se enfrentan entre sí y no se puede proteger incondicionalmente a uno de ellos sin volver inoperante al otro" 35 .

Así, retomando el ejemplo propuesto por el mismo Bobbio, el derecho de libertad de expresión puede enfrentarse con el derecho a no ser ofendido en relación con las propias creencias religiosas y/o morales, con el derecho a no ser difamado, con el derecho a no ser estafado. Además, un ejemplo de más dramática actualidad en los últimos años viene ofrecido por el (presunto) conflicto entre seguridad y paz. Conflicto (presunto) que se ha venido configurando ya como conflicto entre seguridad y libertad y/o como conflicto entre la libertad (rasgo que se reivindica como irrenunciablemente distintivo de los regímenes democráticos de los países occidentales) y las libertades, es decir, las diversas libertades en las que la libertad de las democracias occidentales se ha manifestado tradicionalmente, y de las que hoy se solicitan derogaciones cada vez más numerosas e inquietantes ${ }^{36}$.

\footnotetext{
${ }^{34}$ W.B. Gallie [1956].

${ }^{35}$ N. Bobbio [1968 (1ª), $1992\left(2^{\mathrm{a}}\right)$, p. 39].

${ }^{36}$ Sobre el presunto conflicto entre seguridad y paz, entre seguridad y las libertades tradicionalmente reconocidas en las democracias occidentales, cfr., supra, nota 3. También, sobre
} 
De ordinario los conflictos entre derechos fundamentales derivan de la protección de intereses sociales distintos y/o de valores en conflicto que derechos fundamentales diferentes tienden a realizar. En síntesis, citando una vez más a Bobbio: “A través de la proclamación de los derechos del hombre hemos hecho emerger los valores fundamentales de la civilización humana hasta el momento presente. Cierto, pero los valores últimos son antinómicos: este es el problema"37.

Una última anotación. Contrariamente a lo que quizás se podría pensar, el fenómeno de los conflictos entre derechos fundamentales, independientemente del tipo de configuración que pueda asumir, no es simplemente un caso particular del fenómeno más general del conflicto entre normas (es decir, del fenómeno de las antinomias). Aunque estén relacionados, los dos fenómenos presentan, en efecto, diferencias significativas. Mencionaré tres de ellas.

Una primera diferencia significativa entre antinomias y conflictos entre derechos fundamentales es que, a diferencia de lo que sucede en el caso del conflicto entre normas, no es necesario que los derechos fundamentales en conflicto estén explícitamente expresados por (o sean, al menos, implícitamente reconducibles $a^{38}$ ) disposiciones de Derecho positivo. Dicho de otra forma, mientras que no se puede afirmar que haya un conflicto entre dos normas a menos que cada una de ellas sea jurídicamente válida (es decir, a menos que cada una de las dos normas se encuentre expresada por una disposición de Derecho positivo que no haya sido derogada), es posible, por el contrario, afirmar que hay conflicto entre dos derechos fundamentales también en el caso en que los dos derechos fundamentales no se encuentren ambos expresados por una disposición de Derecho positivo, esto es, también en el caso de que no se encuentren ambos positivizados. Si y en cuanto que se juzga que un derecho es fundamental (es decir, si y en cuanto que pueda ser concebido como un valor a tutelar), su positivización explícita puede no ser considerada como una condición necesaria para su tutela jurídica y/o para su justiciabilidad.

Una segunda diferencia significativa entre los dos fenómenos que ahora examinamos es, además, que no hay criterios gracias a los cuales identificar conflictos entre derechos fundamentales, esto es, que no hay criterios que permitan decidir unívocamente si, y en qué medida, dos derechos están en

la tensión entre seguridad y libertad, entre seguridad y tutela de los derechos fundamentales, cfr, B.C. Ramcharan [2002].

${ }^{37}$ N. Bobbio [1968 $\left.\left(1^{\mathrm{a}}\right), 1992\left(2^{\mathrm{a}}\right), \mathrm{p} .42\right]$.

${ }^{38} \mathrm{Y}$ este es el caso en el que al menos uno de los dos términos de la antinomia viene dado por una norma implícita, es decir, por una norma extraída por vía interpretativa de varias disposiciones. La sugerencia de esta precisión es de Susana Pozzolo. 
conflicto. La competencia y/o la conflictividad depende, en efecto, sobre todo, aunque quizás no exclusivamente, de la lectura de los valores de los que los derechos fundamentales son expresión y/o instrumentos de actuación. Significativo, y dramático, es el caso antes mencionado de la contraposición entre seguridad y libertad, si no directamente entre la libertad y las diversas libertades en que ha encontrado expresión la libertad en las democracias occidentales. Contraposición, ésta, eventual y todo menos obvia: los argumentos de quien reclama una derogación cada vez más amplia y generalizada de las libertades y de los derechos fundamentales en nombre de la seguridad se enfrentan, en efecto, con los argumentos, ciertamente menos drásticos y perentorios, de quien, por el contrario, reivindica una tutela plena y acabada de las libertades y de los derechos fundamentales como condición necesaria e imprescindible de la seguridad.

Una tercera diferencia significativa entre los dos fenómenos que examinamos es, en fin, que, a diferencia de lo que sucede en el caso de normas antinómicas, no está previsto ningún criterio jurídico que permita resolver un conflicto entre derechos fundamentales. Y esto, con independencia del hecho ya subrayado de que los derechos fundamentales estén o no explícitamente positivizados. Los criterios usuales para la resolución de antinomias aparecen, en efecto, como inadecuados en el caso de conflictos entre derechos fundamentales. Esta afirmación vale ante todo para el principio de lex superior y para el principio de lex specialis: ninguno de estos dos criterios proporciona un instrumento idóneo para la resolución de conflictos entre derechos fundamentales, porque los derechos fundamentales, en cuanto tales, tienen la misma relevancia; esto es, comparten el mismo nivel jerárquico $\mathrm{y}$ tienen el mismo ámbito de validez universal. Y tampoco el principio de lex posterior parece ofrecer un instrumento adecuado para la resolución de conflictos entre derechos fundamentales: la emergencia de nuevos derechos fundamentales no entraña, como es obvio, que los precedentemente reconocidos y tutelados se transformen en, por así decirlo, "menos fundamentales".

Las características peculiares de los conflictos entre derechos fundamentales, y las diferencias entre este fenómeno y el aparentemente análogo de los conflictos entre normas, muestran claramente que, de hecho, depende de las diversas posibles preferencias de los jueces el decidir, sobre la base de una discrecionalidad cuantitativamente mayor si no incluso cualitativamente distinta respecto a aquella de la que gozan en caso de conflicto entre normas, cuáles sean, en caso de derechos fundamentales en conflicto, aquellos los que garantizar por medio de tutela judicial. 


\subsection{Dificultades lógicas}

La triple fuente de indeterminación del conjunto de los derechos fundamentales a realizar y/o a tutelar en un ordenamiento jurídico actúa, como es obvio, sobre las formas y sobre los modos en que se configura el razonamiento judicial en las diversas fases en que se articula el proceso decisorio de una controversia.

Actúa, en primer lugar, confirmando y volviendo aún más manifiesta la naturaleza constitutiva y no declarativa tanto de las premisas, jurídica y fáctica, sobre las que se funda la decisión del caso, como de su conclusión, la parte dispositiva (\$3.3.1.).

Y actúa, además, en segundo lugar, confirmando y volviendo aún más manifiesto el carácter tanto derrotable (y/o no monotónico), como aproximativo del razonamiento judicial (§3.3.2.).

\subsubsection{Naturaleza constitutiva de las decisiones judiciales}

Según una tesis ya presente en las primeras formulaciones de la Reine Rechtslehre kelseniana, las decisiones judiciales tienen naturaleza constitutiva y no declarativa ${ }^{39}$. Y precisamente, de una decisión judicial (sea cual sea el tipo de acción que pueda ser objeto de la misma ${ }^{40}$ ), tiene naturaleza no declarativa sino constitutiva tanto la conclusión (la parte dispositiva), porque es el resultado de una deliberación (por parte de un órgano competente) y no de una mera deducción lógica ${ }^{41}$, como las premisas, tanto la jurídica como la fáctica, porque una y otra son el resultado, no de un proceso meramente cognoscitivo de los hechos objeto de la controversia y/o (re)cognoscitivo de las normas a aplicar para su resolución, sino, por el contrario, de un complejo proceso decisorio y valorativo ${ }^{42}$.

\footnotetext{
${ }^{39}$ De esta tesis me he ocupado anteriormentre, en particular en [1992], [1996 a , pp. 57-103], [1999].

${ }^{40}$ La tesis teorética de la naturaleza constitutiva, en una decisión judicial, tanto de su conclusión como de sus premisas, no debe confundirse con la clasificación dogmática según la cual las decisiones judiciales pueden distinguirse, según el tipo de acción que es objeto de las mismas, en declarativas, constitutivas y de condena. Aun no careciendo de relaciones entre sí, la tesis de carácter teorético y la clasificación de carácter dogmático son, sin embargo, cosas distintas y no deben confundirse. Para un análisis más puntual tanto de las diferencias como de las posibles relaciones entre una y otra, cfr. T. Mazzarese [1999].

${ }^{41}$ Que decidir sea cosa distinta de deducir es una observación tan obvia y banal como con frecuencia tenida en poca consideración en los análisis que identifican en el aparato categorial de la lógica clásica una condición irrenunciable para fundamentar y garantizar la "racionalidad" de las decisiones judiciales.

${ }^{42}$ En extrema síntesis, son tres los principales argumentos (dos de los cuales fueron ya formulados por Kelsen) sobre los que se fundamenta la afirmación de la naturaleza constitutiva de la premisa fáctica de una decisión judicial: (a) el primer argumento es que el establecimiento
} 
Ahora bien, la tesis de la naturaleza constitutiva tanto de las premisas, jurídica y fáctica, como de la conclusión de una decisión judicial, recibe una doble confirmación tanto en razón de esos derechos a los que se ha hecho referencia como derechos fundamentales sobre la aplicación judicial del Derecho (§ 2.1.), como en razón de aquellos derechos a los que se ha hecho referencia como derechos fundamentales en la aplicación judicial del Derecho (§ 2.2.).

Los unos, los derechos fundamentales sobre la aplicación judicial del Derecho, confirman y testimonian, en efecto, la variedad y la pluralidad de vínculos jurídicos (ligados a aquello que, de acuerdo con distintos ordenamientos, se entiende por garantía de los derechos de las partes en un proceso) y no epistemológicos (dictados por eventuales cánones objetivos de conocimiento) que van al compás y caracterizan tanto la llamada fase cognoscitiva de los hechos objeto de la controversia, como la llamada fase recognoscitiva del Derecho a aplicar para su resolución.

Los otros, los derechos fundamentales en la aplicación judicial del Derecho, confirman y testimonian la matriz hermenéutica, valorativa y subjetiva, del razonamiento judicial, que hace inadecuado, por cuanto confundente, el recurso a los cánones de la lógica deductiva clásica (como, por ejemplo, respecto a la relación entre conclusión y premisas de una decisión), así como a los cánones de la lógica inductiva clásica y/o de la teoría de la probabilidad (como, por ejemplo, respecto a las diversas fases del establecimiento de los

de los hechos objeto de la controversia debe ser llevado a cabo por un órgano competente; (b) el segundo argumento es que tal establecimiento debe ser llevado a cabo en conformidad con cuanto viene establecido por el ordenamiento jurídico (es decir, en conformidad con cuanto viene establecido por el Derecho sobre prueba); (c) el tercer argumento es que el establecimiento de los hechos objeto de una controversia está condicionado por la calificación jurídica que los hechos tienen según el Derecho, en otros términos, por el supuesto de hecho de la norma general a la que se juzga (o, mejor, se decide) que se pueden reconducir los hechos de la controversia. Son tres también los principales argumentos sobre los que se fundamenta la afirmación de la naturaleza constitutiva de la premisa jurídica de una decisión judicial (argumentos, también en este caso, ya presentes, si bien no siempre explícitamente formulados o examinados con detenimiento, en la obra de Kelsen) : (a) el primer argumento es que la selección de la disposición normativa a la que recurrir para la enunciación de la premisa jurídica es el resultado de una actividad decisoria, y no de una actividad meramente cognoscitiva o recognoscitiva del juez; (b) el segundo argumento es que la selección del significado (entre los diversos significados posibles) a adscribir a la disposición normativa que el juez decide adoptar para la enunciación de la premisa jurídica, es, de manera no diferente de la selección misma de la disposición, el resultado de una actividad decisoria; (c) el tercer argumento es que la aplicación de una norma para la resolución de un determinado caso está condicionada por un juicio de validez sobre la norma seleccionada, juicio que (de manera análoga a la selección de la disposición a adoptar y de la selección de la norma expresada por la disposición adoptada) es el resultado de una actividad decisoria. 
hechos del caso) como instrumentos explicativos del proceso decisional de una controversia.

\subsubsection{Carácter tanto derrotable (y/o no monotónico) como aproximado del razonamiento judicial}

El papel de los derechos fundamentales en la aplicación judicial del Dercho, esto es, el papel que los mismos tienen (pueden y/o deben tener) en la identificación de las dos premisas y en la selección de la decisión (no deducción) de la solución de una controversia, no sólo concurre a confirmar la naturaleza constitutiva y no declarativa de las decisiones judiciales, sino que permite denunciar aquellos rasgos que, en contraste con la asunción (neo)ilustrada del juez boca de la ley, no pueden no ser dos rasgos distintivos del razonamiento judicial: su carácter tanto derrotable (y/o no monotónico) como aproximado ${ }^{43}$.

La derrotabilidad (y/o no monotonicidad) del razonamiento judicial es una obvia consecuencia inmediata de la competitividad (potencial, cuando no real) entre derechos fundamentales distintos y/o entre valores de los que los mismos son expresión. La realización y/o tutela de un derecho fundamental puede enfrentarse, en efecto, con la realización y/o la tutela de un derecho fundamental diferente. Y, además, puede haber competitividad en la realización y/o tutela de un mismo derecho fundamental según la lectura que se asuma y/o se proponga del valor del que el derecho fundamental es expresión (entre los ejemplos quizás más obvios los de la vida, el trabajo, la familia).

Este dato de la competitividad en la realización o en la tutela de derechos fundamentales distintos, si no de un mismo derecho fundamental en razón de lecturas distintas del valor (de los valores) del que el derecho es expresión, incita a la adopción (si no a la experimentación de nuevas formas) de cálculos lógicos derrotables y/o no monotónicos; es decir, de cálculos capaces de dar cuenta de formas de razonamiento y/o de argumentación que, como las formas de razonamiento y/o de argumentación judicial, tengan como objeto datos (potencialmente) en conflicto apoyados por razones más o menos fuertes que, según los casos, pueden prevalecer o ceder respecto a otros datos. Cálculos, en otros términos, en los cuales (a diferencia de los cálculos de la lógica clásica que es monotónica y no derrotable) la introducción de nuevas premisas y/o el cambio de las premisas iniciales entraña un cambio también en las conclusiones, en las consecuencias que son derivables en el cálculo.

${ }^{43}$ Del carácter aproximado del razonamiento judicial me he ocupado anteriormente, en particular en [1996 a, pp. 159-204], [1996 b], [1996-1997]. 
El carácter aproximado del razonamiento judicial es, por el contrario, una obvia consecuencia de cada una de las tres principales fuentes de indeterminación del conjunto de los derechos fundamentales de las que se ha hecho mención. Es decir, el carácter aproximado del razonamiento judicial es una consecuencia obvia tanto de la indeterminación que se deriva de los criterios de identificación de los derechos fundamentales a incluir en la redacción del catálogo de los mismos (y, por tanto, también de las dudas relativas a la pregunta de si tal catálogo debe considerarse cerrado o abierto), como de la indeterminación que se deriva de los criterios de interpretación (de las formulaciones) de los derechos fundamentales incluidos en el catálogo de un ordenamiento determinado tanto en razón de la pluralidad de concepciones de los valores a ellos subyacentes, como en razón de su (potencial) competitividad (sincrónica y diacrónica).

Este dato de la triple fuente de indeterminación del conjunto de los derechos fundamentales de los que garantizar tutela judicial, que estimula la adopción (si no la experimentación de nuevas formas) de cálculos de lógica fuzzy o lógica del razonamiento aproximado; es decir, de cálculos capaces de dar cuenta de formas de razonamiento y/o de argumentación que, como las formas de razonamiento y/o de argumentación judicial, no pueden ser sino aproximadas porque tienen como objeto datos que no pueden sino ser indeterminados ${ }^{44}$.

La lógica fuzzy o lógica del razonamiento aproximado tiene rasgos con seguridad muy poco tranquilizadores (todavía menos tranquilizadores que los de la lógica derrotable y/o no monotónica) para cualquier jurista ligado a una concepción tradicional del dogma de la certeza del Derecho, y tiene incluso característica sospechosas para cualquier lógico hostil a cálculos que, como los de la lógica fuzzy, son no una extensión de la lógica clásica, sino expresión de una de las ya numerosas lógicas divergentes ${ }^{45}$. Según la

\footnotetext{
${ }^{44}$ Aunque sus primeros cálculos se remontan sólo a la segunda mitad del siglo pasado, la literatura sobre la lógica fuzzy es ya muy amplia. Para algunas indicaciones bibliográficas, cfr. T. Mazzarese [1966, p.164, n. 10]; para una lectura introductiva que ofrezca una panorámica de algunas de sus implicaciones teorético-conceptuales y/o de los distintos campos de sus posibles aplicaciones y/o de la variedad de sus configuraciones, cfr., por ejemplo, D. McNeill, P. Freiberger [1993], B. Kosko [1994] y S. Haak [1996, pp. 229-242], A. Sangalli [1998].

${ }^{45}$ Una caracterización particularmente feliz de la noción de lógicas divergentes, caracterización que capta la razón de fondo de la incomodidad que estas lógicas generan usualmente, es ofrecida por W. V.O. Quine [1970, pp. 80-81]: "El tipo de divergencia [...] a tomar en consideración [...] no es simplemente un cambio de los métodos que generan la clase de las verdades lógicas, sino un cambio de la propia clase. No es sólo un cambio de la línea de demarcación entre a qué llamar verdad lógica y a qué llamar verdad extralógica. Se trata, más bien, de un neto rechazo de parte de nuestra lógica como para nada verdadera en absoluto" [cursiva mía]. Un análisis amplio y detallado de los diversos problemas filosóficos relativos a los aspectos
} 
caracterización propuesta por el mismo Zadeh, que ha sido su fundador, de la lógica fuzzy se puede decir "que es una lógica del razonamiento aproximado. En cuanto tal, es una lógica cuyos rasgos distintivos son: (i) valores de verdad fuzzy expresados en términos lingüísticos, como: verdadero, del todo verdadero, más o menos verdadero, bastante verdadero, no verdadero, falso, no del todo verdadero y no del todo falso, etc.; (ii) tablas de verdad imprecisas; y (iii) reglas de inferencia cuya validez es más aproximada que exacta"46.

Esta caracterización de Zadeh es quizás inquietante para quien, tanto en el ámbito jurídico como en el ámbito lógico-filosófico, ve en los cánones y en los principios de la lógica clásica los únicos parámetros de racionalidad y de corrección de cualquier forma de razonamiento (también del razonamiento judicial). La caracterización es quizás inquietante, pero es ciertamente idónea para proporcionar un modelo explicativo del razonamiento judicial que permite dar cuenta de sus muchas aproximaciones, de sus continuos ajustes, de la pluralidad de variables que intervienen para condicionarlo y para informarlo en su ensamblaje y articulación.

(Traducción de Juan Ruiz Manero)

\section{Referencias bibliográficas}

Baccelli, Luca [1999], Il particolarismo dei diritti. Poteri degli individui e paradossi dell'universalismo. Roma, Carocci.

- [2002], Diritti fondamentali: i rischi dell'universalismo. En: T. Mazzarese (ed.), Neocostituzionalismo e tutela (sovra)nazionale dei diritti fondamentali. Torino, Giappichelli, 2002, pp. 117-145.

Barbera, Augusto [1975], Art. 2. En: Commentario della Costituzione a cura di G. Branca Principi fondamentali. Zanichelli, Bologna; Foro Italiano, Roma, pp. 50-122.

Boвbio, Norberto [1965], Sul fondamento dei diritti dell'uomo. En: «Rivista internazionale di filosofia del diritto», 42 (1965), pp. 302-309. Reimpreso en: N. Bobbio, L'età dei diritti, Torino, Einaudi, 1992, pp. 5-16.

- [1968], Presente e avvenire dei diritti dell'uomo. En: «La comunità internazionale», 23 (1968), pp. 3-18. Reimpreso en: N. Bobbio, L'età dei diritti, Torino, Einaudi, 1992, pp. 17-44.

ontológicos, metafísicos, y epistemológicos de las lógicas divergentes es ofrecido por S. Haack [1974] y [1996], una reedición, esta última, del libro de 1974 enriquecida con un capítulo sobre la lógica fuzzy. Es común a ambas ediciones la actitud de desconfianza, si no directamente de hostilidad, frente a las lógicas divergentes; en la introducción a la edición de 1966, Haak, en efecto, afirma: "it is possible that classical logic should turn out to be in need of revision; but none of deviant systems considered is so well-motivated philosophically as seriously to threaten its position" (p. ix).

${ }^{46}$ L. A. Zadeh [1975, p. 407, cursiva del autor]. 
Bulygin, Eugenio [1987], Sobre el status ontológico de los derechos humanos. En: «Doxa» 4 (1987), pp. 79-84. Reimpreso en C.E. Alchourrón, E. Bulygin, Analisis logico y derecho, Madrid, Centro de estudios constitucionales, 1991, pp. 619-625.

Cappelletti, Mauro [1989], The Judicial Process in Comparative Perspective, Oxford, Clarendon Press.

CASSESe, Antonio [1994], I diritti umani nel mondo contemporaneo. Roma-Bari, Laterza.

Celano, Bruno [2002 a], Come deve essere la disciplina costituzionale dei diritti?. En: S. Pozzolo (ed.), La legge e i diritti. Torino, Giappichelli, pp. 89-123.

- [2002 b], 'Defeasibility' e bilanciamento. Sulla possibilità di revisioni stabili. En: «Ragion Pratica», 10 (2002), n. 18, pp. 223-239.

Corso, Guido [1996], Diritti umani. En: «Ragion Pratica», 4, (1996), n.7, pp. 5967.

Dworkin, Ronald [1977], Taking Rights Seriously. Cambridge, Mass., Harvard University Press.

- [2002 a], The Threat to Patriotism. En: «The New York Review of Books», 28 febrero 2002.

- [2002 b], The Troubles with the Tribunals. En: «The New York Review of Books», 25 abril 2002.

Ferrajoli, Luigi [1999], I diritti fondamentali nella teoria del diritto. En: «Teoria Politica», 15 (1999), n. 1, pp. 49-92.

- [2000], I fondamenti dei diritti fondamentali. En: «Teoria Politica», 16 (2000), n. 3, pp. 41-113.

- [2001], Per una sfera pubblica del mondo. En: «Teoria politica», 17 (2001), n. 3, pp. 3-21.

- [2002 a], Quali sono i diritti fondamentali?. En: T. Mazzarese (ed.), Neocostituzionalismo e tutela (sovra)nazionale dei diritti fondamentali. Torino, Giappichelli, 2002, pp. 95-116.

- [2002 b], Lo stato di diritto fra passato e futuro. En: P. Costa, D. Zolo (eds.), Lo stato di diritto. Storia, teoria, critica. Milano, Feltrinelli, 2002, pp. 349-386.

Gallie, Walter Bryce [1956], Essentially Contested Concepts,. En: «Proceedings of the Aristotelian Society», 56 (1955-1956), pp. 167-198.

Guastini, Riccardo [1998], Teoria e dogmatica delle fonti. Milano, Giuffrè.

- [2002], La "costituzionalizzazione" dell'ordinamento. En: T. Mazzarese (ed.), Neocostituzionalismo e tutela (sovra)nazionale dei diritti fondamentali. Torino, Giappichelli, 2002, pp. 147-172.

HaAck, Susan [1974], Deviant Logic. Some Philosophical Issues. Cambridge, Cambridge University Press.

- [1996], Deviant Logic, Fuzzy Logic. Beyond the Formalism. Chicago-London, The University of Chicago Press.

Habermas, Jürgen [1996], Die Einbeziehung des Anderen. Frankfurt am Main, Suhrkamp, 1996.

- [1998], Die postnationale Konstellation. Frankfurt am Main, Suhrkamp. 
HäBerle, Peter [2000], The Constitutional State and its Reform Requirements. In: «Ratio Juris», 13 (2000), n. 1, pp. 77-94.

Hufstedler, Shirley M. [1979], In the Name of Justice. En: "Stanford Lawyer", 14 (1979).

Kelsen, Hans [1934], Reine Rechtslehre. Einleitung in die rechtswissenschaftliche Problematik. Wien, Deuticke.

- [1944], Peace through Law. Chapel Hill, University of North Carolina Press.

Koskenniemi, Martti [1999], The Effect of Rights on Political Culture. En: Ph. Alston (ed.), The EU and Human Rights. Oxford, Oxford University Press, 1999, pp. 99-116.

Kosko, Bart [1994], Fuzzy Thinking. London, Harper Collins Publishers.

Mazzarese, Tecla [1992], Dubbi epistemologici sulle nozioni di 'quaestio facti' $e$ 'quaestio juris'. En: «Rivista internazionale di filosofia del diritto», 69 (1992), pp. 294-320.

- [1993], Judicial Implementation of Fundamental Rights: Three Sorts of Problem. En: M.M. Karlsson, O.P. Jónsson, E.M. Brynjarsdóttir (eds.), Recht, Gerechtigkeit und der Staat. Berlin, Duncker und Humblot, 1993, pp. 203-214.

- [1996], Forme di razionalità delle decisioni giudiziali. Torino, Giappichelli.

- [1996 b], Lógica borrosa y decisiónes judiciales: El peligro de una falacia racionalista. Trad. castigliana di José Juan Moreso. En: «Doxa», 19 (1996), pp. 201-228.

- [1996-1997], Semantic and Pragmatic Fuzziness of Legal Language. En: «Archivum Iuridicum Cracoviense», 29-30 (1996-1997), pp. 43-58.

- [1999], Towards the Semantics of "Constitutive" in Judicial Reasoning. En: «Ratio Juris», 12 (1999), pp. 252-262.

- [2002], Diritti fondamentali e neocostituzionalismo: un inventario di problemi. En: T. Mazzarese (ed.), Neocostituzionalismo e tutela (sovra)nazionale dei diritti fondamentali. Torino, Giappichelli, 2002, pp. 1-69.

- [2003], Is the Age of Rights at a Turning Point?. In: «Finnish Yearbook of International Law». (En prensa)

McNeill, Daniel, Freiberger, Paul [1993], Fuzzy Logic. The Discovery of a Revolutionary Computer Technology - And How It Is Changing Our World. New York, Simon \& Scuster.

MonetTI, Vito [2002], La legislazione antiterrorismo dopo l'11 settembre: il contesto internazionale e l'Italia. En: "Questione giustizia», (2002), n. 1, pp. 51-69.

Moreso, José Juan [2002], Conflitti fra principi costituzionali. En: «Ragion Pratica», 10 (2002), n. 18, pp. 201-221.

PACE, Alessandro [2001], Metodi interpretativi e costituzionalismo. En: «Quaderni costituzionali», 21 (2001), n. 1, pp. 35-61.

Prieto Sanchís, Luis [2002], Neocostituzionalismo e ponderazione giudiziale. En: «Ragion Pratica», 10 (2002), n. 18 pp. 169-200.

Quine, William Van Orman [1970], Philosophy of Logic. Englewood Cliffs N.J., Prentice-Hall.

Ramcharan, Bertrand G. [2001], Human Rights and Human Security. The Hague, Martinus Nijhoff. 
Rolla, Giancarlo [2001], I diritti fondamentali nel costituzionalismo contemporaneo: spunti critici. En: G. Rolla (ed.), Tecniche di garanzia dei diritti fondamentali. Torino, Giappichelli, pp. 3-26.

Ross, Alf [1958], On Law and Justice. London, Stevens.

- [1968], Directives and Norms. London, Routledge and Kegan Paul, 1978.

Sangalli, Arturo [1998], The importance of Being Fuzzy and Other Insights from the Border between Math and Computers. Princeton, Princeton University Press.

TARUffo, Michele [2002], Diritti fondamentali, tutela giurisdizionale e alternative. En: T. Mazzarese (ed.), Neocostituzionalismo e tutela (sovra)nazionale dei diritti fondamentali. Torino, Giappichelli, 2002, pp. 173-188.

TwinIng, William / Miers, David [ $\left.{ }^{1} 1976,{ }^{2} 1982\right]$, How to Do Things with Rules, London, Weidenfeld and Nicolson.

Ubertis, Giulio [2002], Diritti fondamentali e processo penale. En: T. Mazzarese (ed.), Neocostituzionalismo e tutela (sovra)nazionale dei diritti fondamentali. Torino, Giappichelli, 2002, pp. 173-188.

ZadeH, Lofti A. [1975], Fuzzy Logic and Approximate Reasoning. En: «Synthese», 30 (1975), pp. 407-428.

Zagrebelsky, Gustavo [1992], Il diritto mite. Legge diritti giustizia. Torino, Einaudi.

Zolo, Danilo [2002 b], Teoria e critica dello Stato di diritto. En: P. Costa, D. Zolo (eds.), Lo stato di diritto. Storia, teoria, critica. Milano, Feltrinelli, 2002, pp. 17-88. 